UNIVERSIDADE DE BRASÍLIA

FACULDADE DE ARQUITETURA E URBANISMO

CATARINA MORAES DE OLIVEIRA SOMBRIO

ACV de Painéis de Blocos Cerâmicos e Concreto Armado: Um Exercício de Aplicação do Manual do ILCD.

Orientadora: Prof. ${ }^{a}$ Dr. ${ }^{a}$ Raquel Naves Blumenschein

Brasília

2015 
CATARINA MORAES DE OLIVEIRA SOMBRIO

\section{ACV de Painéis de Blocos Cerâmicos e Concreto Armado: Um Exercício de Aplicação do Manual do ILCD.}

Dissertação submetida à Faculdade de Arquitetura e Urbanismo da Universidade de Brasília como parte dos requisitos necessários para a obtenção do grau de Mestre em Arquitetura e Urbanismo.

Orientadora: Prof. a Dr. a Raquel Naves Blumenschein

Brasília 
Brasília, fevereiro de 2015

Sombrio, C. M. O.

ACV de Painéis de Blocos Cerâmicos e Concreto Armado: Um Exercício de Aplicação do Manual do ILCD. 140p.

Dissertação de Mestrado - Universidade de Brasília. Faculdade de Arquitetura e Urbanismo.

$\begin{array}{ll}\text { 1. Avaliação de Ciclo de Vida (ACV) } & \text { 2. Indústria da Construção }\end{array}$

3. Materiais de Construção

4. Tecnologia na Construção

5. Construção Racionalizada

6. Impactos Ambientais 


\title{
ACV de Painéis de Blocos Cerâmicos e Concreto Armado: Um Exercício de Aplicação do Manual do ILCD.
}

\begin{abstract}
Dissertação submetida à Faculdade de Arquitetura e Urbanismo da Universidade de Brasília como parte dos requisitos necessários para a obtenção do grau de Mestre em Arquitetura e Urbanismo.
\end{abstract}

Aprovado por:

Prof. a Raquel Naves Blumenschein, D.S.c. (UnB)

(Orientador)

Prof. Armando Caldeira Pires, D.S.c. (UnB)

(Examinador Interno)

Profa., Sandra Luz D.S.c. (UnB)

(Examinador Externo) 


\section{AGRADECIMENTOS}

Aos meus pais, minha irmã, meu marido e meu filho, pela dedicação, amor e união que me trazem paz.

À professora e orientadora Raquel Naves Blumenschein pelos ensinamentos e pela oportunidade.

Aos amigos que me deram força e incentivo durante esta empreitada, no programa do mestrado ou nas atividades profissionais, em especial à Katia Miller que me ajudou muito nesta dissertação.

Aos professores da banca, pela disponibilidade.

A todos que participaram de alguma forma na elaboração deste trabalho.

E a Deus, como sempre, por tudo. 


\section{RESUMO}

A cadeia produtiva da indústria da construção (CPIC) é um dos maiores setores industriais no Brasil e no mundo, tendo grande representatividade econômica e gerando grandes impactos ambientais. $\mathrm{Na}$ busca de aumentar produtividade e reduzir os prejuízos ao meio ambiente os processos construtivos racionalizados vem sendo utilizados na produção de habitações de interesse social. Para a especificação de materiais com menor impacto ambiental, a avaliação do ciclo de vida (ACV) tem sido vista como uma ferramenta eficiente pois permite a avaliação do desempenho ambiental de materiais e produtos da CPIC, possibilitando a comparação entre materiais e o planejamento de construções com menores impactos ambientais. A ACV é normatizada pelas ISO 14040 e 14044 e detalhada por outras metodologias como a do ILCD, que foi adotada como padrão pelo PBACV. Neste estudo, aplica-se a ferramenta de ACV em um produto pré-fabricado da indústria da construção, que integra um processo construtivo racionalizado de edificações, aplicado na construção de habitações de interesse social no Distrito Federal, exercitando um método de aplicação da metodologia do Internacional Reference Life Cicle Data System (ILCD), analisando as dificuldades deste processo diante dos recursos e dados disponíveis. Os resultados do estudo demonstram a destoante participação do concreto nos impactos produzidos pela fabricação do produto, resultado que, considerando o grande uso do concreto na construção civil brasileira, aponta para a busca de sistemas alternativos como uma possível solução para minimizar o problema. O estudo contribui para a geração de dados nacionais referentes ao material estudado, ao mesmo tempo em que permite a estruturação dos conteúdos dos manuais do ILCD, por meio de questionários, que podem ser utilizados em outros estudos e na capacitação de ACV. 


\begin{abstract}
The supply chain of the construction industry (CPIC) is one of the largest industrial sectors in Brazil and in the world, with great economic representation and generating large environmental impacts. In seeking to increase productivity and reduce environmental damage the streamlined construction processes have been used in the production of social housing. For the specification of materials with lower environmental impact, life cycle assessment (LCA) has been seen as an effective tool that allows the assessment of the environmental performance of materials and products of CPIC, enabling the comparison of materials and the design of buildings with lower environmental impacts. LCA is standardized by the ISO 14040 and 14044 and detailed by other methods such as the ILCD, which was adopted as a standard by PBACV. This study applies the LCA tool in a prefabricated product of the construction industry, which includes a streamlined construction process of buildings, applied in construction of social housing in Federal District, Brazil, exercising one method of application of the methodology proposed by the International Reference Life Cycle Data System (ILCD), analyzing the difficulties of this process on the available resources and data. The study results demonstrate the great participation of the concrete in the impacts produced by the manufacture of the product, a result which, considering the large use of concrete in the Brazilian construction, points to the search for alternative systems as a possible solution to minimize the problem. The study contributes to the generation of national data for the studied material, while allowing the structuring of the contents of ILCD manuals, through questionnaires, which can be used in another studies and in the training of LCA.
\end{abstract}




\section{LISTA DE FIGURAS}

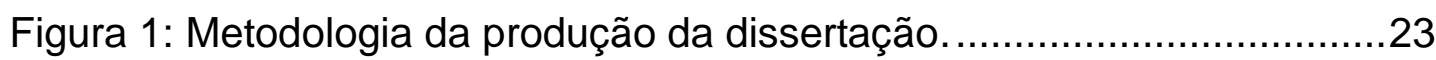

Figura 2: Passos metodológicos, resultados e contribuições da pesquisa. ..26

Figura 3: Fases da ACV. Fonte ISO 14040:2009 30

Figura 4: Fluxos linear e cíclico no ciclo de vida de uma edificação (KHUN, 2006 apud GRICOLLETI, 2001 E HARRIS, 1999).

Figura 5: Prioridades a considerar no projeto para uma construção sustentável (TORGAL E JALALI, 2010 APUD MATEUS, 2008). 40

Figura 6: Inserção e desenvolvimento do conceito de sustentabilidade na construção (KHUN,2006 apud INTERNATIONAL COUNCIL FOR RESEARCH AND INNOVATION IN BUILDING AND CONSTRUCTION, 1999).

Figura 7: Projeto da casa com indicação dos painéis e detalhamento dos painéis. .52

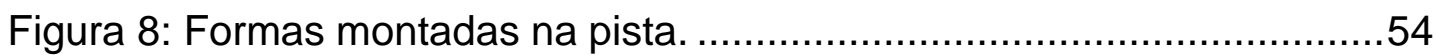

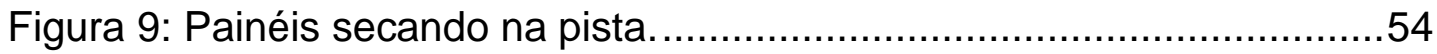

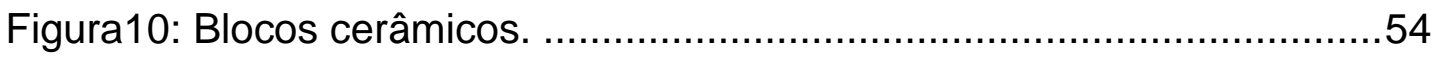

Figura 11: Caminhão Munck carregado com os painéis..............................54

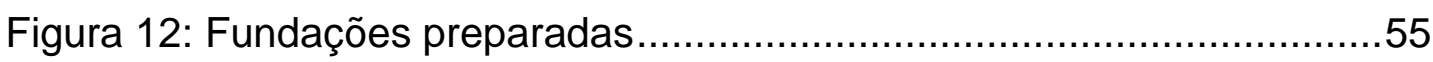

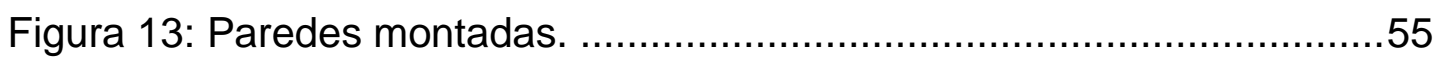

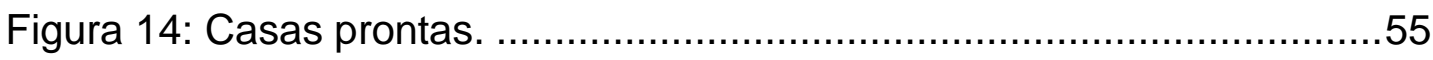

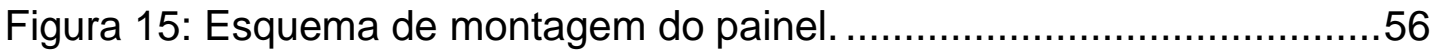

Figura 16: Esquema de aplicação da ACV segundo o ILCD. Fonte WOLF et al, 2012. .60

Figura 17: Estudo dos painéis para definição da unidade funcional. .68

Figura 18: Representação da unidade funcional - uma fração do painel com a mesma proporção de elementos do todo. 70

Figura 19: Opções para definição dos limites do sistema. Fonte: PE International..... .73

Figura 20: Limites do sistema da ACV do painel de blocos cerâmicos e concreto armado.

Figura 21: Divisão dos processos em níveis. Fonte: EUROPEAN COMMISSION, 2010 
Figura 22: Divisão dos processos do painel de blocos cerâmicos e concreto armado. .78

Figura 23: Modelo do sistema montado no software Gabi 6.0 …................. 80

Figura 24: Modelo do sistema, com os processos e fluxos. 80

Figura 25: Divisão dos processos adotada no estudo do painel de blocos cerâmicos e concreto armado. .83

Figura 26: Gráfico de contribuições para o potencial de aquecimento global. 89

Figura 27: Gráfico de contribuições para o potencial de depleção da camada de ozônio. .91

Figura 28: Gráfico de contribuições para o potencial acidificação. .92

Figura 29: Gráfico de contribuições para potencial eutrofização. 94

Figura 30: Gráfico de contribuições para o potencial de formação fotoquímica de ozônio. .95

Figura 31: Gráfico de contribuições para o potencial de depleção de recursos abióticos elementos

Figura 32: Gráfico das contribuições para o potencial de depleção de recursos abióticos fósseis. .99

Figura 33: Categorias de impactos mais representativas segundo normalização do CML 2001 104

Figura 34: Gráficos que demonstram as alterações nos impactos relacionadas às distâncias percorridas 107

Figura 35: Diferença nos resultados dos cálculos dos impactos com a alteração da fonte de dados sobre o concreto. 


\section{LISTA DE TABELAS}

Tabela 1: Relação dos artigos segundo abordagem do tema, país e ano de publicação.

Tabela 2: Quantidade dos artigos segundo abordagem do tema 44

Tabela 3: Diretriz do SINAT sobre sistemas construtivos. Fonte: Zanone e Sanchez

Tabela 4: Diretriz do SINAT sobre o CASA EXPRESS.Fonte: Zanone e Sanchez 49

Tabela 5: Imagens do processo de produção do painel. 54

Tabela 6: Imagens da construção da casa. .55

Tabela 7: Vantagens e desvantagens dos sistemas construtivos préfabricados de blocos cerâmicos .56

Tabela 8: Tabela dos passos pedidos pelo ILCD - Fase de Objetivo. Fonte: EUROPEAN COMMISSION, 2010.

Tabela 9: Tabela dos passos pedidos pelo ILCD - Fase de Escopo. Fonte: EUROPEAN COMMISSION, 2010

Tabela 10: Tabela dos passos identificados pelo ILCD - Fase de Inventário. Fonte: EUROPEAN COMMISSION 2010.

Tabela 11: Materiais referentes à unidade funcional: quantidades, unidades e massas. 79

Tabela 12: Distâncias consideradas para o transporte de materiais. 81

Tabela 13: Origem dos dados.

Tabela 14: Tabela dos passos pedidos pelo ILCD - Fase de cálculo do AICV. Fonte: EUROPEAN COMMISSION, 2010.

Tabela 15: Resultados para a categoria de impacto PAG - Potencial de aquecimento global. .88

Tabela 16: Fluxos que contribuem para PAG - Potencial de aquecimento global. 89

Tabela 17: Resultados para a categoria de impacto para PDO - Potencial de depleção da camada de ozônio .90

Tabela 18: Fluxos que contribuem para PDO - Potencial de depleção da camada de ozônio. 90 
Tabela 19: Resultados para a categoria de impacto para PA - Potencial de acidificação.

Tabela 20: Fluxos que contribuem para PA - Potencial de acidificação. .....93

Tabela 21: Resultados para a categoria de impacto para PE - Potencial de eutrofização. .93

Tabela 22: Fluxos que contribuem para PE - Potencial de eutrofização......94

Tabela 23: Resultados para a categoria de impacto PFFO - Potencial de formação fotoquímica de ozônio.

Tabela 24: Fluxos que contribuem para para PFFO - Potencial de formação fotoquímica de ozônio.

Tabela 25: Resultados para a categoria de impacto para PDA - Elementos Potencial de depleção de recursos abióticos - elementos.

Tabela 26: Fluxos que contribuem para para o Potencial depleção de recursos abióticos - elementos.

Tabela 27: Resultados para a categoria de impacto para ADP - Elementos Potencial de depleção de recursos abióticos - elementos.

Tabela 28: Fluxos para a categoria de impacto potencial de depleção de recursos abióticos - fósseis. 100

Tabela 29: Tabela dos passos identificados pelo ILCD - Fase de Análise dos Resultados dos Cálculos de Impactos. Fonte: EUROPEAN COMMISSION 2010. . 100

Tabela 30: Processos mais representativos de cada impacto. 102

Tabela 31: Processos mais representativos de cada impacto. 106

Tabela 32: Processos mais representativos de cada impacto. 107

Tabela 33: Alteração dos valores devido à alteração dos dados do processo do concreto. 109

Tabela 34: Acréscimo em porcentagem nos impactos avaliados com a alteração dos dados do concreto. 109

Tabela 35: Dados brasileiros no banco de dados disponível para compra da PE International.

Tabela 36: Gargalos na aplicação da matodologia do ILCD e na realização da ACV. 


\section{LISTA DE SIGLAS E ABREVIAÇÕES}

ABNT - Associação Brasileira de Normas Técnicas

Abramat - Associação Brasileira da Indústria de Materiais de Construção

ACV - Avaliação do Ciclo de Vida

AICV - Análise de Impacto do Ciclo de Vida

ADP - Abiotic Depletion Potencial - Potencial de epleção de Recursos Abióticos

AP - Acidification Potencial - Potencial de Acidificação

BRE - Building Research Establishment

CBCS - Conselho Brasileiro de Construção Sustentável

CEMPRE - Compromisso Empresarial de Reciclagem

CETEA - Centro de Tecnologia e embalagem

CFC - gás Cloro-Flúor-Carbono

CILCA - Congresso Internacional de Avaliação de Ciclo de Vida

CML - Instituto de Ciências Ambientais da Universidade de Leiden, Holanda

CML - IA - Banco de dados que contém fatores caracterizantes para a AICV, desenvolvido pelo $\mathrm{CML}$

CONMETRO - Conselho Nacional de Metrologia, Normalização e Qualidade Industrial CPIC - Cadeia Produtiva da Indústria da Construção

DF - Distrito Federal

EN - Norma Européia

EP - Eutrophication Potencial - Potencial de Eutrofização

EPDs - Declarações Ambientais de Produtos

GEE - Gases do Efeito Estufa

GWP - Global Warm Potencial - Podtencial de Aquecimento Global

IBICT - Instituto Brasileiro de Informação, Ciência e Tecnologia

IBGE - Instituto Brasileiro de Geografia e Estatística

ICV - Inventário de Ciclo de Vida

ILCD - International Reference Life Cicle Data System

Inmetro - Instituto Nacional de Metrologia, Qualidade e Tecnologia

MCTI - Ministério da Ciência e Tecnologia e Inovação

MDIC - Ministério do Desenvolvimento, Indústria e Comércio Exterior

MMC - Métodos Modernos de Construção

NBR - Norma Brasileira 
NHBC - National House Builders Council

ONG - Organização Não Governamental

ODP - Ozone Depletion Potencial - Potencial de Depleção da Camada de Ozônio

PA - Potencial de Acidificação

PAG - Potencial de Aquecimento Global

$\mathrm{PE}$ - Potencial de Eutrofização

PBAC - Programa Brasileiro de Avaliação da Conformidade

PBACV - Programa Brasileiro de Avaliação de Ciclo de Vida

PBQP-H - Programa Brasileiro de Qualidade e Produtividade no Habitat

PDA - Potencial de Depleção Abiótica

PDO - Potencial de Depleção de Ozônio

PFFO - Potencial de Formação Fotoquímica de Ozônio

PIB - Produto Interno

PMCMV - Programa Minha Casa Minha Vida

POCP - Photochemical Ozone Creation Potencial - Potencial de Formação

Fotoquímica de Ozônio

RECIPE - Método de indicadores de ACV desenvolvido pela empresa PRÉ

SETAC - Society for Environmental Toxicology and Chemistry

SICV - Inventário do Ciclo de Vida para Competitividade Ambiental da Indústria Brasileira

SINAT - Sistema Nacional de Avaliação Técnica de Produtos

SINMETRO - Sistema Nacional de Metrologia, Normalização e Qualidade Industrial TRACI - Tool for Reduction and Assessment of Chemical and Other Environmental Impacts.

UNEP - United Nations Environmental Program

VOCs - Compostos Orgânicos Voláteis

WCED - Comissão Mundial de Meio-Ambiente e Desenvolvimento

ZEB - Zero Energy Building 


\section{SUMÁRIO}

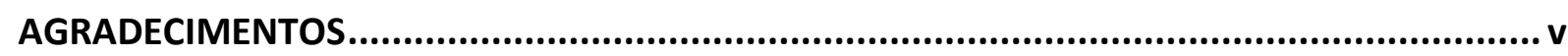

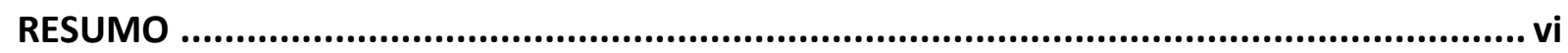

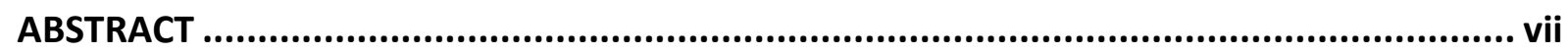

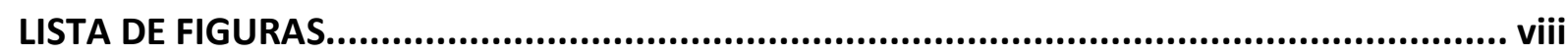

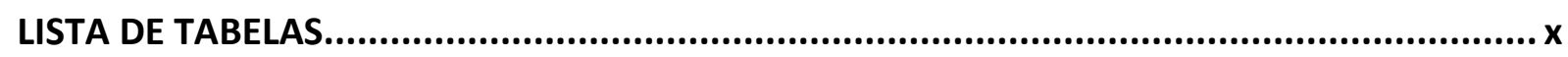

LISTA DE SIGLAS E ABREVIAÇÕES ........................................................................ xii

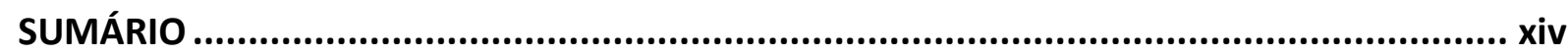

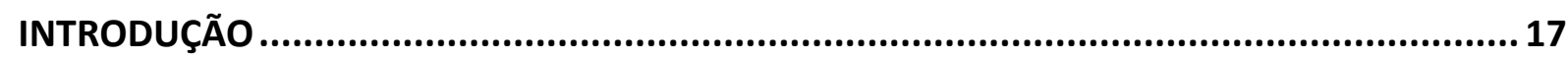

I.I Objetivo Geral ______________________ 22

I.II Objetivos Específicos ___ 22

II. Metodologia ____________________ 22

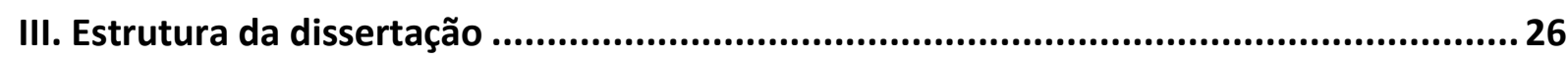

Capítulo 1: Avaliação de Ciclo de Vida e Seu Uso em Materiais e Produtos da CPIC........... 28

1.1 Sobre a ACV___ 28

1.2 A ACV no Brasil ___ _ _ _ 32

1.3 Impactos ambientais dos materiais de construção e a ACV. ___ 34

1.4 Estudos de ACV na CPIC ___ 41

1.5 Sintese Analítica ___ 44

Capítulo 2: Painel Pré-Moldado de Blocos Cerâmicos e Concreto...................................... 45

2.10 Sistema Casa Express ___ 50

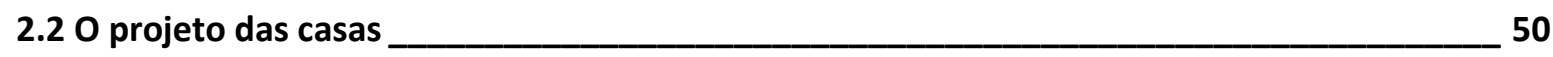

2.30 processo construtivo do painel

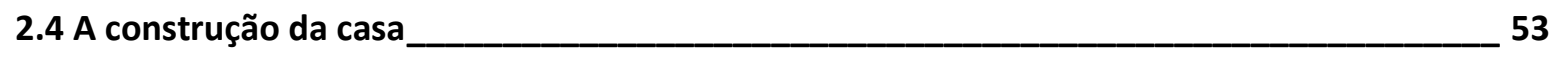

2.5 Esquema do processo produtivo ___ 56

2.6 Síntese Analítica. ___ 57

Capítulo 3: ACV: Aplicação da metodologia do ILCD no painel de bloco cerâmico e concreto. 59 
3.1 Fase de Definição de Objetivo. 61

3.2 Fase de Definição do Escopo. 63

3.3 Definição da unidade funcional. 66

3.4 Modelagem do Inventário de Ciclo de Vida (ICV). 70

3.5 Limites do Sistema 72

3.6 Fase de Inventário 74

3.7 Cálculo dos resultados da AICV. 85

3.8 Síntese Analítica 86

Capítulo 4: Resultados do ICV - AICV. 87

4.1 Cálculo dos Impactos Ambientais. 87

4.1.1 Potencial de Aquecimento Global ou Mudança Climática. 87

4.1.2 Depleção da Camada de Ozônio. 89

4.1.3 Potencial de Acidificação. 91

4.1.4 Potencial de Eutrofização. 93

4.1.5 Formação Fotoquímica de Ozônio. 94

4.1.6 Esgotamento de Recursos Abióticos - Elementos. 96

4.1.7 Esgotamento de Recursos Abióticos - Fósseis. 98

4.2 Análise dos Resultados dos Cálculos de Impactos. 100

4.2.1 Estágios do ciclo de vida mais representativos 101

4.2.2 Categorias de impacto mais representativas 103

4.2.3 Escolhas relevantes durante a modelagem 105

4.2.4 Precisão e qualidade dos dados 105

4.3 Análise de sensibilidade. 106

4.3.1 Sensibilidade à distância percorrida. 106

4.3.2 Sensibilidade à alteração da fonte de dados 108

Considerações Finais 112

Sobre os resultados da ACV. Error! Bookmark not defined.

Sobre a aplicação da metodologia do ILCD. 114

Referências Bibliográficas . 
Anexo 02: Questionário derivado da metodologia do ILCD. 133 


\section{INTRODUÇÃO}

As discussões sobre o tema da sustentabilidade ambiental ganharam força em todos os países desde 1987, quando a Comissão Mundial de Meio-Ambiente e Desenvolvimento (WCED) publicou um relatório solicitando uma estratégia que unisse desenvolvimento e preservação ambiental (ORTIZ; CASTELLS; SONNEMANN, 2009).

Os motivos da preocupação estão relacionados principalmente à concentração de $\mathrm{CO}_{2}$ na atmosfera que resulta no aumento da temperatura média do ar causando alterações climáticas com graves consequências, mas também estão relacionados a elevados índices de urbanização, exagerada exploração de recursos naturais, alta liberação de resíduos, entre outros (ORTIZ; CASTELLS; SONNEMANN, 2009).

A pegada humana global, que considera o consumo de recursos naturais pela humanidade cresceu $80 \%$ de 1960 a 2000 . Todos os anos são consumidos no mundo 1,2 vezes mais recursos naturais do que a sua capacidade de renovação (WEIBENBERGER et al, 2014).

Muitas indústrias tornaram-se foco de atenção, incluindo a indústria da construção. Maior empregador da Europa, segundo Ortiz et al (2009), em 2006 contava com $7 \%$ do total de empregos e $28 \%$ dos empregos industriais.

No âmbito ambiental este setor é um grande consumidor de energia, sendo responsável nos países industrializados por $70 \%$ do consumo de eletricidade, $12 \%$ do consumo de água potável e $40 \%$ da extração dos recursos naturais. É também grande gerador de resíduos, produzindo $45-65 \%$ dos resíduos depositados em aterros (FRANZONI, 2011).

Contribui ainda com $40 \%$ das emissões atmosféricas, $20 \%$ dos efluentes líquidos, 25\% dos sólidos e 13\% de outras liberações (SANTOS et al, 2011, apud ARAÚJO, 2002).

Agentes ligados à CPIC, como fabricantes, arquitetos, usuários e proprietários, estão cada vez mais em busca de informações que permitirão a avaliação do processo produtivo da edificação e de seus componentes e irão embasar 
decisões ligadas a impactos ambientais das edificações e de outros setores da construção (ORTIZ; CASTELLS; SONNEMANN, 2009).

Entre as ferramentas que permitem a geração de informações relevantes citase a Avaliação de Ciclo de Vida (ACV), que é padronizada pela ISO 14040:2006 Gestão Ambiental - Avaliação de Ciclo de Vida - Princípios e Estrutura; e pela ISO 14044:2006 - Gestão Ambiental - Avaliação de Ciclo de Vida - Requisitos e Orientações.

De acordo com a norma NBR 14040 (ABNT, 2006), a ACV deve incluir a definição de objetivo e escopo, análise de inventário, avaliação de impactos e interpretação de resultados. A base de uma ACV é o Inventário do Ciclo de Vida (ICV), uma aferição quantitativa de todas as cargas ambientais ao longo do ciclo de vida de um produto (BUENO et al, 2011).

A partir da década de 80, com a reinterpretação da Agenda 21 nos contextos específicos das agendas locais e setoriais que foram desenvolvidas, a preocupação com o desempenho ambiental das edificações já na fase do projeto arquitetônico ganhou força (Bueno et al, 2011). A ACV é utilizada na cadeia produtiva da indústria da construção (CPIC) desde 1990 tendo uma grande importância na avaliação de edificações (ORTIZ; CASTELLS; SONNEMANN, 2009).

A CPIC é uma cadeia muito complexa, que envolve diversos materiais de construção e componentes, o que dificulta a aplicação da ACV, devido à falta de disponibilidade de dados, complexidade na comparação dos resultados e alto custo de aplicação (BUENO et al, 2011).

A aplicação da ACV nos produtos da CPIC envolvem avaliação de desempenho ambiental de materiais de construção e de edificações, rotulagem ambiental de produtos, ferramentas computacionais de suporte à decisão e auxílio ao projeto e esquemas de avaliação/certificação ambiental de edifícios (HELPA; SOARES; 2011 apud SILVA 2003).

As edificações, como produtos da CPIC, são complexas e apresentam grandes dificuldades para a realização da ACV. É difícil determinar as fronteiras de seu sistema, passo necessário para a realização do estudo, pois têm longa vida útil, sofrem constantes alterações, podem ter funções múltiplas, têm uma grande 
diversidade de componentes, são frequentemente produtos únicos, produzidos localmente, integrados com a infraestrutura urbana, entre outras características (BUENO et al, 2011).

O desempenho ambiental dos edifícios é normalmente avaliado pelo seu desempenho energético e pelos atributos dos materiais utilizados. Os atributos dos materiais de construção considerados normalmente são: custo, durabilidade, renovabilidade, teor reciclado, entre outros. Para a avaliação do desempenho ambiental é importante considerar também a emissão de resíduos e o uso e depleção de recursos naturais (BUENO et al, 2011).

Entre os materiais de construção utilizados, além de produtos simples, a CPIC se caracteriza pela utilização de produtos complexos, que englobam materiais, componentes, subsistemas e combinações. Para a obtenção de dados sobre desempenho ambiental desta variedade de produtos, a ACV se apresenta como uma reconhecida ferramenta de avaliação (BUENO et al, 2011).

No processo de projeto e especificação de uma edificação, a escolha de materiais com melhor desempenho ambiental é o procedimento que exerce maior influência no desempenho do edifício durante todo o seu ciclo de vida (BUENO et al, 2011).

Além da escolha dos materiais e componentes, as atividades no canteiro de obras também interferem no resultado sobre o desempenho ambiental da edificação. A alta produção de resíduos, o desperdício de materiais, a geração de ruídos, entre outros fatores, interferem diretamente nos resultados.

Neste contexto os sistemas construtivos racionalizados surgem como uma alternativa aos métodos tradicionais, prometendo maior agilidade e menor desperdício alcançados por meio de projetos específicos que permitem detalhar a execução e quantificar com maior precisão a necessidade de materiais e componentes.

Em países desenvolvidos, com maior produção tecnológica, novos métodos são amplamente utilizados. No Reino Unido sistemas pré-fabricados são denominados Métodos Modernos de Construção (MMC) e são incentivados pelo governo, que precisa atender à demanda habitacional de forma rápida e com custo 
reduzido. Estes incentivos chegam ao construtor por meio de financiamentos ou uso de terras pertencentes ao governo (NHBC FOUNDATION, 2006).

Segundo o guia produzido pela NHBC Foundation (2006), o segmento do governo britânico que gerencia o setor habitacional, conhecido por "Housing Corporation", classificou seis tipos de sistemas construtivos classificados como MMC:

- Produzido na indústria - volumétrico: como exemplo de produto volumétrico citam-se os banheiros completos que podem ser produzidos na indústria e chegam prontos para serem encaixados na obra.

- Produzido na indústria - painéis: Os painéis normalmente são utilizados como vedação.

- Produzido na indústria - híbrido: construções que unem componentes volumétricos e painéis.

- Produzido na indústria - subconjuntos e componentes: são grandes componentes que são incorporados à obra como fundações préfabricadas, estruturas metálicas, telhados, chaminés, etc.

- Métodos modernos de construção não produzidos na indústria: são métodos inovadores construídos no local ou o uso de materiais tradicionais que uma forma inovadora.

O governo e os construtores britânicos apostam em benefícios como maior qualidade da construção, pois materiais industriais são produzidos em um ambiente controlado; maior eficiência termo acústica, característica exigida pelas normas de edificação do país; o menor custo da habitação, já que o preço final apresentado pelo construtor inclui o material a ser utilizado, desestimulando o desperdício; e a menor geração de resíduos, beneficiando o meio ambiente (NHBC FOUNDATION, 2006).

Entre os sistemas construtivos racionalizados utilizados no Brasil citam-se a alvenaria estrutural, os painéis de vedação pré-fabricados, vedações de concreto moldadas no local, entre outros.

A solução da vedação vertical composta por painéis pré-moldados entra no mercado brasileiro como uma opção ao sistema convencional na busca por novas tecnologias construtivas que podem racionalizar o processo de construção. 
Estes sistemas objetivam melhores níveis de desempenho na produção com a diminuição dos custos e do tempo de construção, um maior controle de qualidade na produção e redução do número de assentadores qualificados (CESAR; ROMAN, 2006).

Alguns modelos de painéis pré-moldados já são aprovados pelo Sistema Nacional de Avaliação Técnica de Produtos (SINAT) e estão sendo utilizados em larga escala na construção de casas populares, o que justifica sua escolha para um estudo de impacto ambiental.

Pesquisas sobre o desempenho ambiental de métodos construtivos ainda são incipientes no Brasil. Elas são importantes na busca pela diminuição do impacto da CPIC. Quando tratamos de um método utilizado para produção de habitações em grande quantidade potencializamos o benefício da informação (KHUN, 2006).

Uma ACV precisa exige uma equipe especializada, uma metodologia bem definida e uma coleta de dados cuidadosa, com a geração de dados específicos e a utilização de banco de dados regionais que devem estar disponíveis aos estudiosos. No Brasil os recursos ainda são limitados e poucos dados estão disponíveis.

O objetivo desta dissertação é realizar o estudo de ACV em um produto préfabricado da indústria da construção, exercitando um método de aplicação da metodologia do Internacional Reference Life Cicle Data System (ILCD) que sistematiza a aplicação da metodologia do ILCD e ajuda na identificação de gargalos. 


\section{Objetivos}

\section{I.I Objetivo Geral}

Aplicar a metodologia do ILCD em um sistema de vedação vertical utilizado no DF para a construção de habitações de interesse social - painel pré-moldado de blocos cerâmicos e concreto armado - exercitando um método de aplicação desta metodologia a produtos da indústria da construção, visando a identificar gargalos e oportunidades na aplicação da ACV.

\section{I.II Objetivos Específicos}

- $\quad$ Entender a ACV por meio da metodologia do ILCD;

- $\quad$ Entender os benefícios da ACV de materiais de construção;

- $\quad$ Sistematizar a metodologia do ILCD;

- Identificar gargalos e oportunidades na aplicação da ACV no setor da construção e propor diretrizes para subsidiar a elaboração de estratégias de fortalecimento da ACV no setor da construção.

\section{Metodologia}

O planejamento para a construção desta pesquisa teve como base a identificação das atividades necessárias para conhecimento e desenvolvimento do tema. Estas atividades foram divididas em etapas, que posteriormente se transformaram nos capítulos da dissertação, conforme esquematizado na Figura 1. 


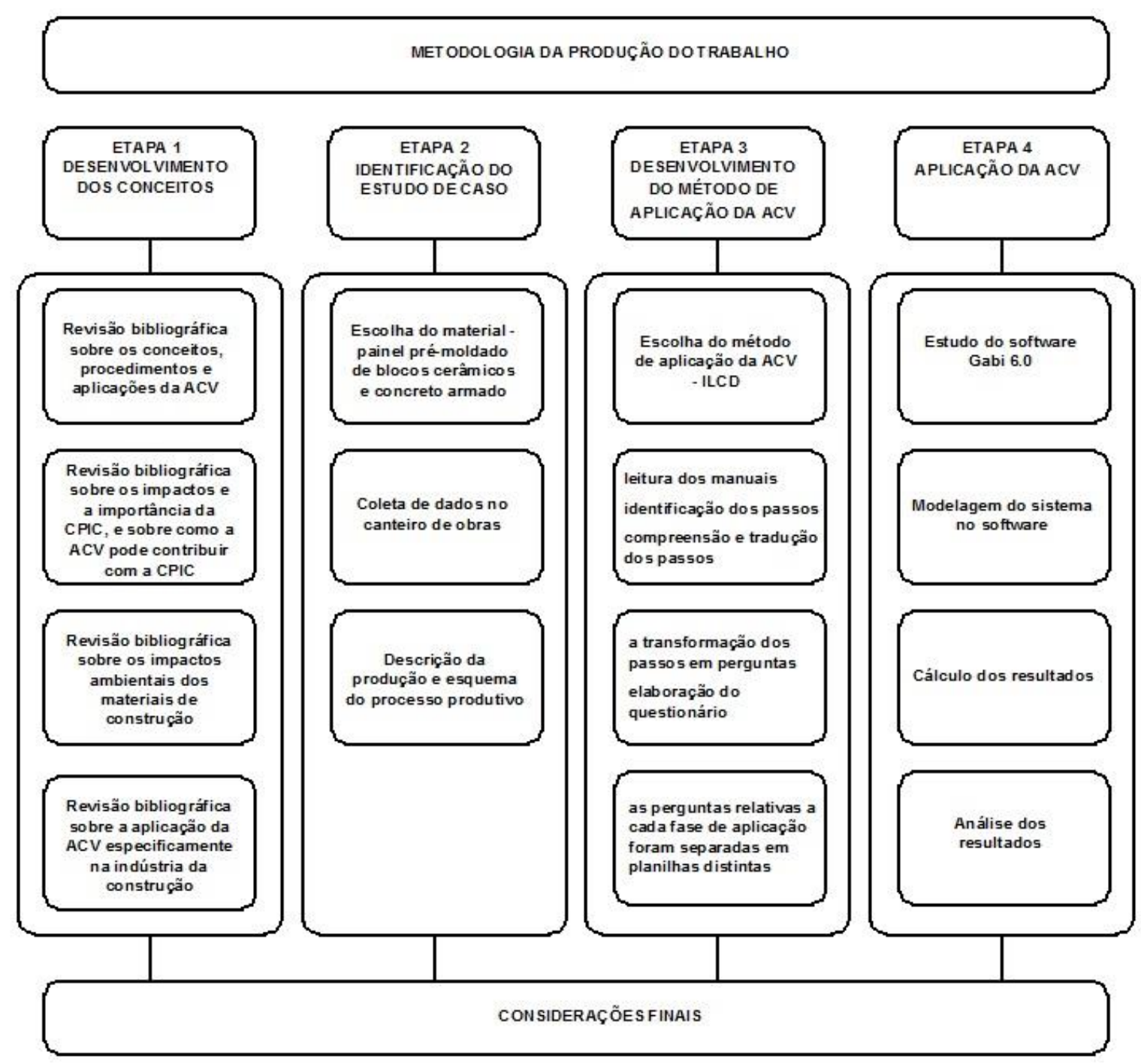

Figura 1: Metodologia da produção da dissertação.

\section{II.I Etapa 1}

$\mathrm{Na}$ primeira etapa, o objetivo foi compreender o conceito, o histórico e o funcionamento da ACV, contextualizá-la dentro da CPIC e conhecer o desenvolvimento do tema dentro da produção científica.

Esta etapa envolveu a revisão bibliográfica sobre os conceitos, procedimentos e aplicações da ACV, a revisão bibliográfica sobre os impactos e a importância econômica da CPIC, e sobre como a ferramenta da ACV pode contribuir para um melhor desempenho ambiental desta indústria. 
Tendo compreendido que a ACV pode auxiliar no processo de diminuição dos impactos da CPIC desde a fase de extração de matérias primas, passando pelos processos produtivos de materiais de construção, partiu-se para um aprofundamento, por meio de revisão bibliográfica, sobre os impactos ambientais dos materiais de construção e em seguida sobre a aplicação da ACV especificamente na indústria da construção, mostrando como ela já vem contribuindo nas pesquisas sobre desempenho ambiental de produtos da CPIC.

\section{II.II Etapa 2}

A segunda etapa teve como objetivo a seleção do material a ser objeto de aplicação da ferramenta. O painel pré-moldado de blocos cerâmicos e concreto despertou interesse por estar sendo utilizado para a construção de casas populares no DF, e por ser um material com possibilidade de ampla utilização, boa aceitação pelos usuários e que, segundo os fabricantes, contribui para a construção inteligente, rápida e com pouco desperdício.

Selecionado o material e contatado o construtor, foi feita uma visita ao canteiro de obras onde os painéis são construídos e a um dos locais onde as casas são montadas. Nesta visita foram coletados dados importantes como o projeto dos painéis, a relação e a quantidade de materiais utilizados e o procedimento de produção.

Com base nos dados coletados nesta visita foi elaborada a descrição passo a passo da produção do painel de blocos cerâmicos e concreto armado e elaborado um esquema do processo produtivo.

\section{II.III Etapa 3}

Para o início da aplicação da ferramenta da ACV foi selecionada a metodologia de aplicação desenvolvida pelo ILCD, que seria aplicada por meio do estudo e tradução dos passos descritos em seus manuais.

Depois das definições do objetivo e escopo do estudo os passos dos manuais do ILCD que se adequavam à situação prevista nestas primeiras fases e que eram destacados como passos obrigatórios foram identificados e sistematizados com a utilização de planilhas.

O desenvolvimento deste método envolveu: 
- A leitura do resumo dos manuais;

- A identificação dos passos relacionados ao estudo dos painéis prémoldados de bloco cerâmico e concreto armado;

- A transformação destes passos em perguntas a serem respondidas durante o seguimento da aplicação da ferramenta, que resultaram no questionário apresentado no Anexo I.

No momento da aplicação da ferramenta, para facilitar ainda o manuseio e a dinâmica da aplicação deste questionário, as perguntas relativas a cada fase de aplicação foram separadas em planilhas distintas, com campos para as respostas. No início de cada fase as planilhas eram revisadas e a aplicação da ferramenta seguia os passos estabelecidos. A fase só era considerada completa quando todos os campos relativos às respostas estavam preenchidos.

O desenvolvimento do método de aplicação da ferramenta resultou em um sistema de perguntas e respostas que podem servir de guia para a aplicação da ACV, como foi utilizado neste trabalho, e também podem servir de guia para a avaliação de ACVs segundo as exigências do ILCD. Ainda, podem ser utilizadas no treinamento da utilização da ferramenta e na formação de revisores de ACV.

\section{II.IV Etapa 4}

A etapa seguinte foi o estudo do software Gabi 6 Education por meio dos tutoriais presentes na página da PE Internacional, a modelagem do sistema no software, a inserção de todos os dados levantados e o cálculo dos impactos realizado pelo programa.

De acordo com os cálculos do programa Gabi 6 Education e com a planilha com as questões relativas à análise dos resultados os gráficos foram analisados e comentados.

Para concluir sobre o procedimento de estudo e aplicação da ferramenta, sobre as dificuldades com a metodologia do ILCD e sobre o desenvolvimento de questionários e planilhas foi elaborado o capítulo de considerações finais.

A Figura 2 mostra os passos metodológicos, resultados e contribuições do estudo. 


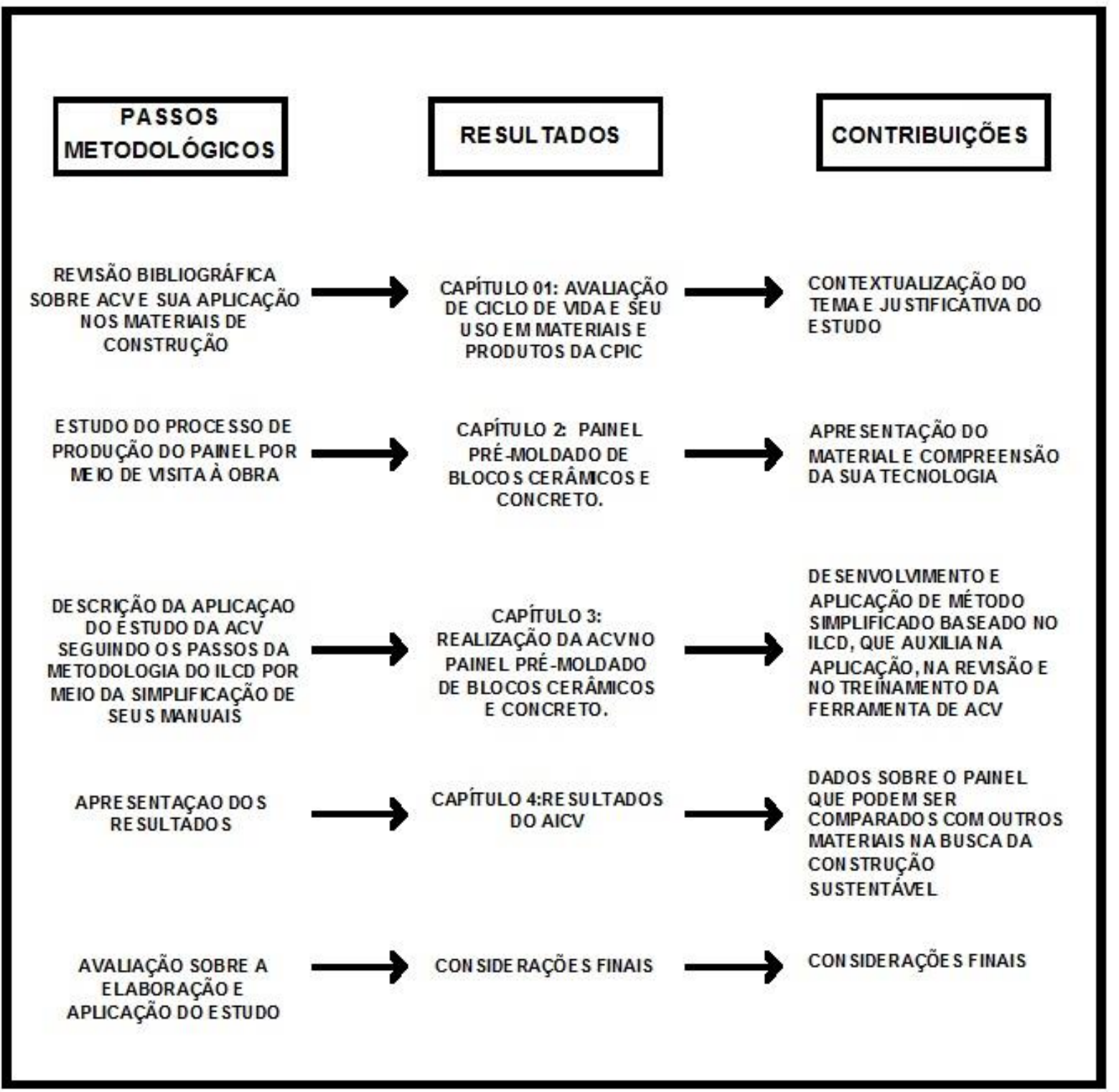

Figura 2: Passos metodológicos, resultados e contribuições da pesquisa.

\section{Estrutura da dissertação}

Esta dissertação estrutura-se em introdução, quatro capítulos e considerações finais.

O primeiro capítulo apresenta o conceito de avaliação de ciclo de vida (ACV), descreve um breve histórico do desenvolvimento da ACV no Brasil, identifica os impactos ambientais associados aos materiais de construção e os benefícios de se realizar a ACV nos produtos na indústria da construção e cita exemplos de estudos que vem sendo realizados no mundo sobre ACV em materiais de construção. 
segundo capítulo justifica o uso de novos processos construtivos para a construção de habitações. Fala dobre o Sistema Nacional de Avaliação Técnica de Produtos (SINAT) e a validação de novas alternativas tecnológicas para produtos e processos inovadores da construção civil no Brasil. Apresenta o sistema de painéis pré-moldados de blocos cerâmicos e concreto como uma das tecnologias aprovadas e descreve o processo construtivo do painel segundo informações colhidas em visita técnica à obra.

No capítulo 3 , os manuais que descrevem a metodologia do ILCD são estudados e compreendidos, os passos que se aplicam ao estudo dos painéis prémoldados de blocos cerâmicos e concreto armado são identificados e sistematizados em perguntas que devem ser respondidas para completar e facilitar a aplicação da ferramenta. As perguntas formam um questionário que em seguida é organizado em planilhas separadas por fases de aplicação da ACV que são seguidas para a aplicação da ACV no material escolhido.

Seguindo as planilhas, as fases de objetivo, escopo, inventário de dados e cálculo das entradas e saídas do processo são desenvolvidas no capítulo 4. O estudo foi realizado com a utilização do software Gabi 6 Educational, da PE International, que auxilia no fornecimento de dados e no cálculo dos fluxos.

O capítulo 5 apresenta os cálculos das categorias de impacto escolhidas com os gráficos, tabelas informativas e comentários sobre os resultados encontrados.

Nas considerações finais analisa-se o processo de elaboração da pesquisa proposta, identificando os gargalos da realização do estudo. Conclui sobre a viabilidade da aplicação do questionário e das planilhas desenvolvidas segundo os passos do manual e sobre quais as contribuições que o método utilizado pode oferecer para o desenvolvimento da ACV no Brasil. 


\section{Capítulo 1: Avaliação de Ciclo de Vida e Seu Uso em Materiais e Produtos da CPIC}

A compreensão do conceito de ACV, seus objetivos, histórico e procedimentos gerais de sua aplicação são importantes para a compreensão de como esta ferramenta pode auxiliar no desenvolvimento mais sustentável da CPIC. Os grandes impactos negativos causados ao meio ambiente pela indústria da construção e principalmente pelo processo produtivo dos materiais de construção justificam a busca por soluções que minimizem o problema.

A ACV é considerada atualmente a ferramenta mais eficaz na identificação dos impactos ambientais de produtos e na busca por alternativas menos prejudiciais ao meio ambiente, e sua aplicação na CPIC está sendo estudada por pesquisadores no mundo todo.

Este capítulo apresenta informações sobre a ACV; sobre os impactos causados pela CPIC e pela produção de materiais de construção; e exemplos de estudos que vêm sendo desenvolvidos no mundo sobra a aplicação da ACV na CPIC.

\subsection{Sobre a ACV}

A ACV é uma ferramenta de desempenho ambiental definida na ISO 14040:2009 que enfoca aspectos ambientais e os impactos ambientais potenciais ao longo de todo o ciclo de vida de um produto, desde a aquisição de matérias-primas, produção, uso, tratamento pós-uso, reciclagem até a disposição final (ISO 14040:2009 p. v).

Segundo a definição do Manual ILCD (WOLF et al, 2012), a Avaliação de Ciclo de Vida (ACV) é um método científico, estruturado e abrangente, que tem o objetivo de quantificar o consumo de recursos e emissões, assim como os impactos ambientais na saúde, e questões de esgotamento de recursos associados a qualquer bem ouserviço. Isto engloba mudanças climáticas, poluição do ar, ecotoxidade, efeitos cancerígenos, esgotamento de recursos naturais, etc. Ela permite a comparação entre produtos baseada na performance quantitativa das alternativas analisadas (European Comission, 2010).

Para Caldeira-Pires et al. (2005), a Avaliação do Ciclo de Vida (ACV) ajuda a identificar oportunidades de melhoria no desempenho ambiental dos produtos e pode 
promover mudanças tecnológicas fundamentais tanto na produção quanto nos produtos em razão do efeito multiplicador ao longo da cadeia de produção, inclusive no uso otimizado de energia e de materiais, por meio da utilização de processos de reciclagem e de reuso.

A ferramenta da ACV permite quantificar a energia incorporada dos materiais, que representa a energia consumida na extração de matérias-primas, na produção, no transporte, na desmontagem e/ou descarte (FRANZONI, 2011).

A técnica da ACV começou a ser desenvolvida por volta do final da década de 1960 e início da década de 1970 nos Estados Unidos para a empresa Coca-Cola, com a intenção de avaliar o desempenho ambiental das embalagens. Porém estes estudos nunca foram divulgados por conter informações confidenciais. Nesta época os dados sobre as embalagens e as perdas do processo recebiam maior atenção que o consumo de energia e a poluição do meio-ambiente (WEIBENBERGER et al, 2014 apud HUNT AND FRANKLIN, 1996).

Os estudos de avaliação de desempenho ambiental de produtos foram se aprimorando e com isso o novos aspectos precisaram ser considerados nos resultados como as emissões para o ar, os efluentes líquidos e a produção de resíduos (SANTOS et al, 2010).

A realização da ACV constitui-se no desmembramento do processo produtivo do material avaliado considerando as entradas e saídas de matéria, água e energia em cada etapa permitindo a avaliação de seus impactos no meio-ambiente e na saúde humana (CALDEIRA-PIRES, 2005).

O processo é dividido em cinco fases, conforme Figura 3, que são descritas na série ISO, sendo que a ISO 14040 descreve a definição de objetivo e definição do escopo do estudo, a ISO 14041 faz referência ao inventário do ciclo de vida, a ISO 14042 e ISO 14048 à avaliação dos impactos e a ISO 14043 à interpretação dos resultados. Há ainda a ISO 14049 que normaliza a execução de relatórios técnicos (CALDEIRA-PIRES, 2005). 


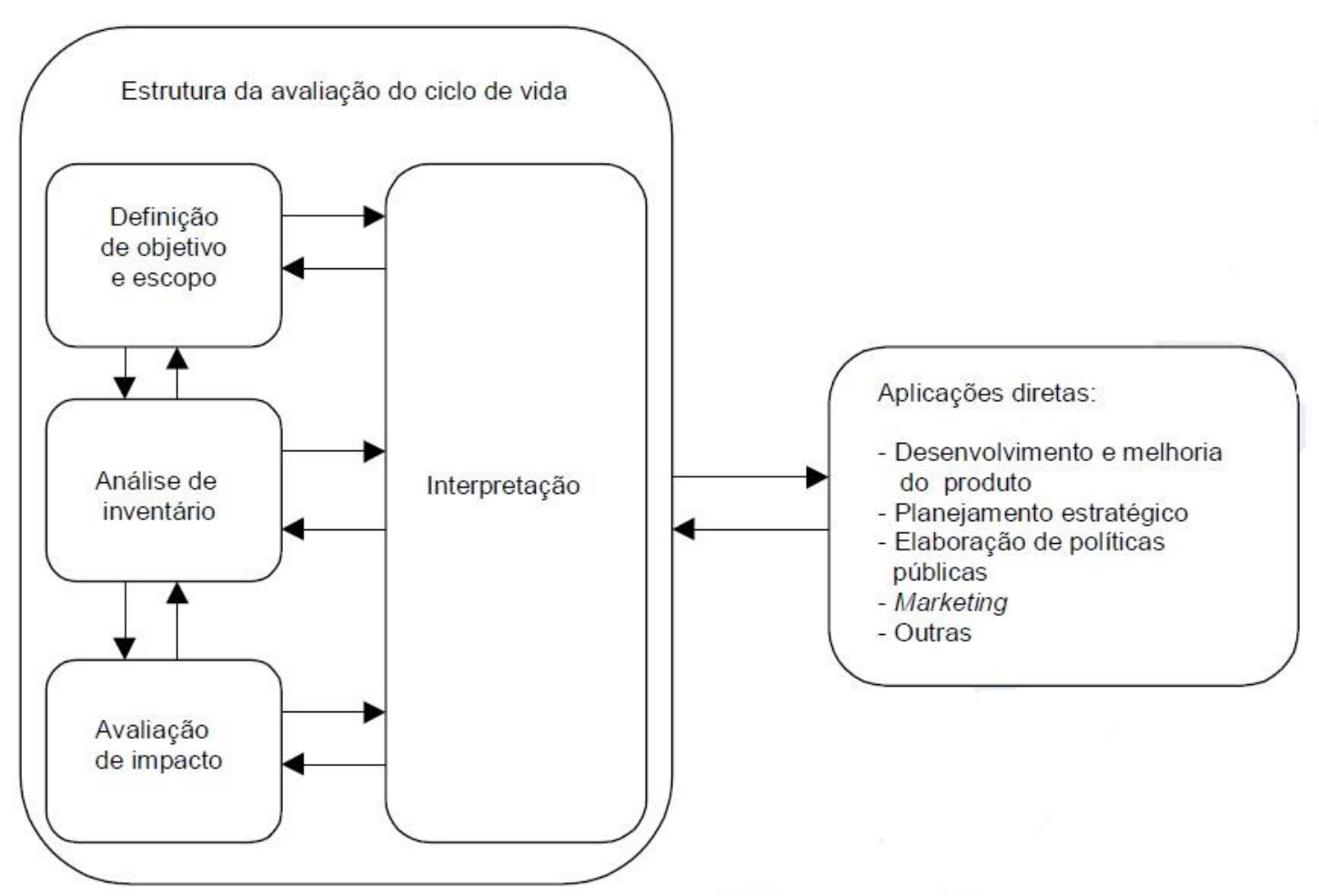

Figura 3: Fases da ACV. Fonte ISO 14040:2009

$\mathrm{Na}$ definição do objetivo deve-se identificar: qual é a aplicação do estudo; quais são as limitações previstas; as intenções da realização do estudo; o público alvo a quem o estudo se dirige; quais são os impactos a serem avaliados; se haverá comparação entre produtos; o envolvimento das partes interessadas; entre outros itens importantes que norteiem a realização dos passos posteriores (WOLF et al, 2012).

A fase de escopo deve descrever o sistema a ser estudado, definir a função do objeto a ser estudado, uma unidade funcional a ser considerada, o fluxo de referência do processo produtivo, os estágios do ciclo de vida que serão considerados, os métodos de inventário de ciclo de vida que serão aplicados, a interpretação que será usada, as suposições feitas sobre os dados e o método, a escolha de valores, limites, qualidade do banco de dados, tipos de revisão crítica, e o tipo e formato do relatório. Nesta fase deve-se também identificar as fronteiras do sistema a ser estudado, definindo o que está incluído no sistema principal e o que faz parte do sistema secundário (WOLF et al, 2012). 
$\mathrm{Na}$ fase de inventário de ciclo de vida (ICV) planeja-se a coleta de dados definindo quais serão as fontes, quais dados poderão ser coletados diretamente do processo produtivo (dados primários) e quais dados serão retirados de banco de dados ou de outros estudos (dados secundários) e efetiva-se a coleta com a intenção de identificar as entradas e saídas de matéria e energia durante cada etapa do processo produtivo. Esta fase inclui ainda a modelagem da ACV do sistema analisado. Isso engloba o uso de informações de ciclo de vida anteriores dos produtos utilizados. Após o ICV é possível a primeira validação do sistema (WOLF et al, 2012).

Esta é a fase mais longa e trabalhosa do procedimento de realização da ACV. A coleta de dados deve ser avaliada e reavaliada em função da qualidade dos dados coletados, dos dados faltantes e das soluções para problemas encontrados ao longo do desmembramento do processo produtivo, como a multifuncionalidade de produtos e processos (WOLF et al, 2012).

Em seguida, tem-se a fase de avaliação dos impactos causados pelas emissões identificadas na fase de inventário. Essa avaliação será norteada pela definição feita na fase de objetivo e escopo sobre quais impactos interessam ao estudo que podem ser: mudanças climáticas, acidificação, saúde humana, ecotoxicidade aquática, esgotamento de recursos naturais, uso de terra, etc. (WOLF et al, 2012).

$\mathrm{Na}$ fase de interpretação dos resultados avalia-se se os resultados alcançados que atendem as questões definidas na fase de objetivo e escopo. A interpretação inclui checagens consistentes e identifica as incertezas e a precisão dos resultados. Tem como objetivo alcançar conclusões e recomendações (WOLF et al, 2012).

A utilização da ACV para a avaliação de produtos traz vantagens ao mercado consumidor e principalmente ao meio-ambiente pois seus resultados auxiliam no aprimoramento do processo produtivo e no desenvolvimento dos produtos de uma empresa, permitem comparar o desempenho ambiental de produtos concorrentes, assistem a tomada de decisões da indústria, do governo e das ONGs na definição de prioridades e no desenvolvimento de projetos e processos, podendo assim subsidiar estratégias de marketing que ofereçam produtos com declarações ambientais (JUNIOR et al, 2008). 
O Manual ILCD cita ainda benefícios como o auxílio na criação de rótulos ambientais, projetos ambientais (ecodesign) e no cálculo das pegadas de carbono; orientação em questões estratégicas sobre impactos ambientais e a potencial melhoria no uso de recursos naturais; orientação para o desenvolvimento de tecnologias e ajuda na quantificação do desempenho ambiental de locais de produção e de empresas.

\subsection{A ACV no Brasil}

Países desenvolvidos já praticam a ACV de forma isolada desde o final da década de 1960 e início da década de 1970 motivados principalmente pela avaliação dos impactos das embalagens. Os estudos realizados nestes países são aplicados pela academia, governo e indústrias. Em países em desenvolvimento os estudos vêm sendo realizados principalmente pela academia e por algumas empresas (LIMA, 2007).

Os primeiros artigos nacionais sobre a avaliação do ciclo de vida dos produtos foram publicados no Brasil na década de 90, impulsionados pelo tema do desenvolvimento sustentável que ganhou destaque no país após a realização da Conferência ECO 92 no Rio de Janeiro (SANTOS et al, 2010).

A versão nacional da norma internacional ISO, a NBR ISO 14.040 (2001) é lançada no Brasil em 2001 e no ano seguinte o Compromisso Empresarial para a Reciclagem (CEMPRE), em parceria com o Centro de Tecnologia de Embalagem (CETEA) publica uma apostila com os princípios e aplicações da ACV (SANTOS et al.).

A AVC tornou-se tema estratégico do Programa Brasileiro de Avaliação da Conformidade (PBAC) em 2004. Em 2007 o Ministério da Ciência e Tecnologia (MCT) aprovou o projeto Inventário do Ciclo de Vida para Competitividade Ambiental da Indústria Brasileira (SICV Brasil) que tem como objetivo desenvolver o banco de dados de inventário do ciclo de vida da indústria de base do Brasil ( http://pbacv.blogspot.com.br/p/quem-somos.html em 29/09/2013).

Também em 2007 é realizado o primeiro evento de ACV no Brasil, na cidade de São Paulo: o Congresso Internacional de Avaliação de Ciclo de Vida - CILCA (SANTOS et al, 2010). 
Em 2009, o Instituto Brasileiro de Informação em Ciência e Tecnologia (IBICT) e a Comissão Europeia e a United Nations Environment Program/Society for Environmental Toxicology and Chemistry (UNEP/SETAC) assinam acordo de cooperação para apoiar as ações da base de dados de inventário do ciclo de vida e disseminar 0 pensamento do ciclo de vida no Brasil (http://pbacv.blogspot.com.br/p/quem-somos.html em 29/29/2013).

Em 22 de abril de 2010 o Programa Brasileiro de Avaliação de Ciclo de Vida (PBACV) é aprovado pela Resolução oㅡ 03 do Conselho Nacional de Metrologia, Normalização e Qualidade Industrial (CONMETRO) do Ministério do Desenvolvimento, Indústria e Comércio Exterior (MDIC) com o objetivo de estabelecer diretrizes para o Sistema Nacional de Metrologia, Normalização e Qualidade Industrial (SINMETRO) e de dar continuidade às ações de ACV no Brasil.

As intenções principais do PBACV incluem a implantação de um sistema reconhecido internacionalmente que contenha, organize e distribua informações padronizadas sobre inventários de ACV da produção industrial brasileira; a formação de pessoas especializadas; o apoio ao desenvolvimento e o acesso à mecanismos de distribuição de informações sobre o conceito do ciclo de vida; a intervenção e influência nos trabalhos de normalização internacional e nacional referentes a ACV; e a identificação das principais categorias de impactos ambientais para ० Brasil (http://pbacv.blogspot.com.br/p/quem-somos.html em 29/29/2013).

Em 2011 foi concluída a segunda versão do repositório de inventário do Brasil chamado de SICV Brasil, e foi realizada a primeira reunião do Comitê Gestor do PBACV.

As ações citadas acima auxiliam o desenvolvimento e a normalização da realização dos estudos de ACV. No entanto, este processo no Brasil ainda enfrenta dificuldades como identificado por Lima (2007):

- A alta exigência de recursos para a elaboração do estudo,

- O longo tempo dispendido no processo,

- A falta de pessoal capacitado, 
- A falta de banco de dados, principalmente os que fornecem informações regionais e atualizadas que são essenciais para o resultado preciso da $\mathrm{ACV}$,

- A falta de incentivos fiscais por parte do Estado às empresas que se propuserem a melhorar seus processos e produtos,

- A utilização de metodologias estrangeiras, que não se adequam em muitos pontos às diversidades regionais, entre outras.

Países desenvolvidos como a Suíça, Alemanha, Japão e EUA possuem bancos de dados extensos de inventários de ciclo de vida relativos às condições de seus territórios (LIMA, 2007).

A produção de um banco de dados nacional é de grande importância para a precisão do resultado pois na ACV são consideradas extração de recursos, fontes de energia, meios de transporte, distâncias percorridas e diversos outros fatores que são peculiares à cada local de produção.

Ainda, a ACV de um produto exige conhecimento das implicações ambientais de outros produtos que fazem parte do seu processo produtivo, para os quais necessita-se informações sobre seu ciclo de vida. Produtos muito utilizados em diversos processos como água, energia, produtos químicos básicos, madeira, aço, alumínio, papel, diesel entre outros, devem constar em um banco de dados com informações regionalizadas para facilitar a expansão da aplicação da ferramenta em outros produtos (CALDEIRA-PIRES, 2005).

1.3 Impactos ambientais dos materiais de construção e a ACV.

No modelo linear de produção industrial que vigora na economia atual os produtos são projetados, produzidos, utilizados e descartados no meio ambiente. Este procedimento ligado ao grande aumento populacional e à cultura de consumo vigente tem como consequência, principalmente em países industrializados, um alto consumo energético, escassez de matérias primas e de locais para disposição de resíduos (SANTOS et al, 2011).

Em resposta a este cenário surge uma corrente com uma nova proposta produtiva baseada nos ciclos de vida da natureza, chamada Life Cicle Design, ou ciclo de vida de um produto. A nova proposta baseia-se em uma visão sistêmica do 
processo de produção, buscando integrar suas fases e considerar as trocas entre produto e meio ambiente durante toda a sua vida, com a finalidade de dimensionar e reduzir seus impactos ambientais (SANTOS et al, 2011).

A Figura 4 abaixo ilustra o fluxo da produção, vida útil e descarte de uma edificação de forma linear, finalizando o processo na disposição final, e de forma cíclica, que busca integrar fases e reutilizar recursos.

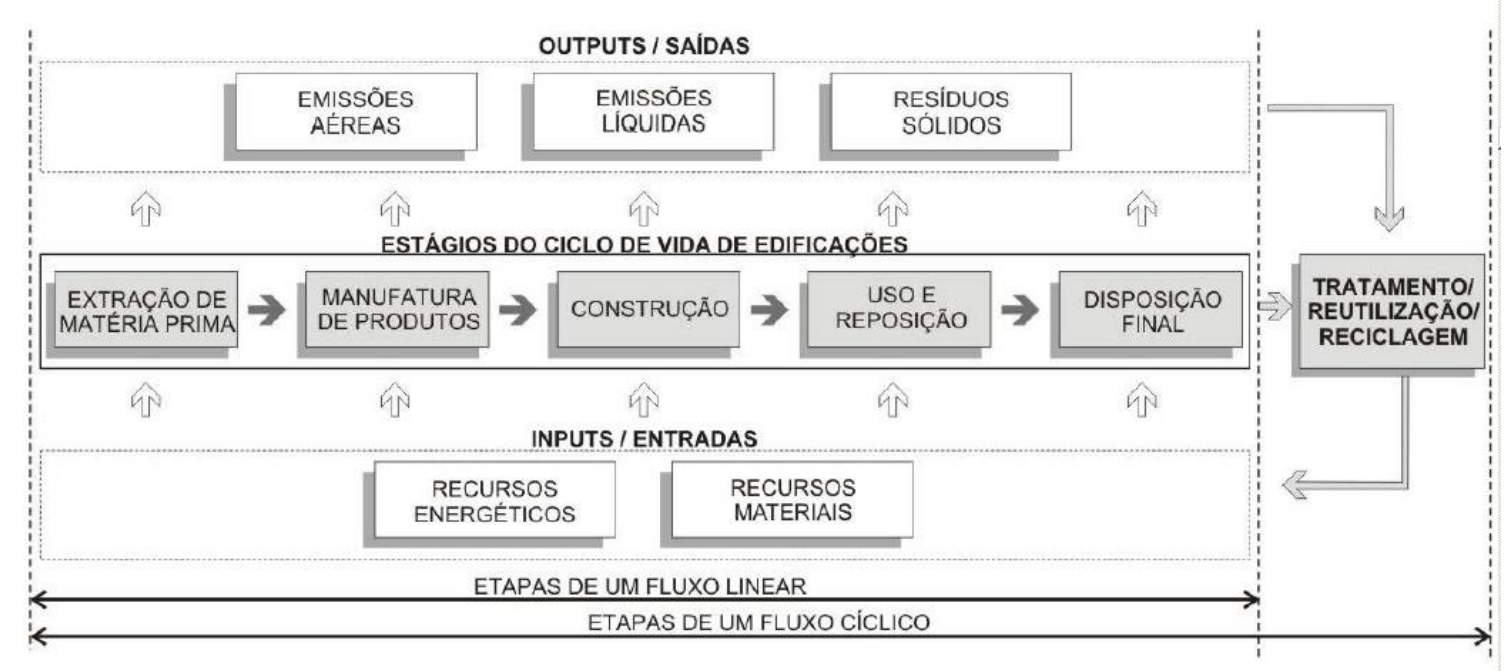

Figura 4: Fluxos linear e cíclico no ciclo de vida de uma edificação (KHUN, 2006 apud GRICOLLETI, 2001 E HARRIS, 1999).

A ideia desta corrente é que a utilização de recursos naturais seja otimizada, que os desperdícios e perdas sejam minimizados, que os rejeitos sejam recicláveis e incorporados novamente à cadeia produtiva do mesmo produto, ou de outro produto, gerando a chamada simbiose industrial (SANTOS et al, 2011).

A ACV é o método que analisa o produto durante toda a sua vida útil, identifica as trocas com o meio ambiente e conclui sobre os impactos dos produtos analisados. Segundo o Conselho Brasileiro de Construção Sustentável (CBCS, 2009), a ACV é "a melhor ferramenta para selecionar produtos com base em critérios de ecoeficiência." Seus resultados permitem a busca de alternativas menos danosas durante o processo produtivo e a comparação entre produtos finais oferecidos aos consumidores. 
Os produtos industriais podem ser classificados e comparados entre si pela elaboração de perfis ambientais que resultam em selos, rótulos e declarações ambientais de produtos.

A Série ISO 14020 trata sobre os selos, rótulos e declarações ambientais, sendo dividida em três tipos principais:

- Tipo I (ISO 14024) - Selo: Padrões Ambientais que fornecem "Ecoselos".

- Tipo II (ISO 14021) - Rótulos: características auto declaradas, ex: "reciclável".

- Tipo III (ISO 14025) - Declarações: declaração ambiental de produtos seguindo uma formula prescrita, conforme tabelas nutricionais;

Estes documentos são embasados pela ISO 14020 - Selos Ambientais e Declarações - Princípios Gerais (BRE, 2007).

Todo o processo de elaboração dos selos, rótulos ou declarações são baseados em estudos de ACV dos produtos da indústria da construção.

As declarações ambientais que se encaixam nos rótulos ambientais Tipo III, referentes à ISO 14025, são as que mais geram expectativas de utilização nas relações comerciais. Elas podem gerar diferenciais competitivos para os produtos num mercado cada vez mais exigente em relação ao desempenho ambiental (LIMA, 2007).

Para a elaboração destas declarações ambientais a Building Research Establishment (BRE) desenvolveu uma metodologia padrão de identificação dos impactos ambientais associados aos materiais de construção durante seu ciclo de vida. Este método baseia-se na elaboração de Declarações Ambientais de Produtos (EPDs) e permite que projetistas tenham acesso a informações confiáveis e comparativas sobre materiais de construção equivalentes e dá aos fornecedores a oportunidade de apresentar informações ambientais confiáveis sobre seus produtos.

A declaração ambiental de produtos é similar à informação nutricional encontrada nos rótulos de embalagens de alimento. Eles listam os impactos causados durante a vida de um produto. A informação deve ter uniformidade, consistência, 
confiabilidade e clareza. O uso das EPDs na cadeia produtiva da indústria da construção (CPIC) tem como objetivo encorajar a demanda e o fornecimento de materiais e produtos que causem menor prejuízo ao meio ambiente por meio da comunicação de informações precisas e confiáveis sobre os aspectos ambientais destes materiais e produtos (BRE, 2007).

Sobre a CPIC, Blumenschein (2004, p. 57) esclarece que "o impacto ambiental causado pela edificação, como produto principal da CPIC, ocorre ao longo de toda a cadeia. Seu processo de produção gera impacto e condiciona a ambiência tanto pelo processo como pelo produto. Ao longo de toda esta cadeia, recursos naturais são explorados e utilizados, energia é consumida e resíduos são gerados".

Segundo Torgal e Jalali (2010), a CPIC é a indústria que mais consome matérias primas no mundo, e resulta em muitos produtos pouco eficientes que exigem alto consumo de energia durante sua vida útil.

Com relação ao período de vida útil da edificação, muita atenção foi direcionada nas últimas décadas à estudos e esforços para a redução do consumo energético da edificação. Neste contexto surgiu o conceito do Zero Energy Building (ZEB) que implica em um edifício com o balanço anual entre a energia consumida para a operação do edifício e a energia utilizada de fontes renováveis próximo a zero (FRANZONI, 2011).

A União Européia estabeleceu uma diretriz em 2010 que indica que todos os edifícios públicos devem atingir a meta do balanço anual próximo a zero até 2018 e todos os novos edifícios devem atingir esta meta até 2020 (FRANZONI, 2011).

Os avanços nos estudos com o objetivo de redução dos impactos ambientais da edificação direcionaram os olhares para a fase de construção da edificação e para os impactos dos materiais de construção, que engloba a extração de matéria prima, processos de produção, transporte, etc. (FRANZONI, 2011).

Materiais de construção apresentam grandes problemas ambientais na fase de extração de matéria prima, que provoca o esgotamento de recursos e alto impacto no processo de extração (TORGAL e JALALI, 2010 apud Whitmore, 2006). 
O índice de aproveitamento de recursos em relação à produção de resíduos é de $0,15 \%$. O risco de acidentes em explorações mineiras é alto e causa prejuízos à natureza e à saúde humana (TORGAL e JALALI, 2010 apud Whitmore, 2006).

Além dos impactos ocorridos na fase de extração de matéria prima, os impactos ocorridos na fase de produção de componentes e uso dos materiais também são importantes. O ideal é que não sejam tóxicos, apresentem baixa energia incorporada, sejam recicláveis, permitam o reaproveitamento de resíduos, provenham de fontes renováveis, estejam associados a baixas emissões de gases do efeito estufa (GEE), sejam duráveis e sejam escolhidos mediante dados avaliados pela ferramenta de ACV (TORGAL e JALALI, 2010 apud Whitmore, 2006).

Segundo Franzoni (2011), a energia incorporada de materiais de construção representam de $2 \%$ a $38 \%$ da energia consumida durante 50 anos de vida útil em edifícios convencionais e de $9 \%$ a $46 \%$ em edifícios de baixo consumo de energia. Por esta razão o conceito de edifícios com zero consumo de energia (ZEB) vem sendo questionado por estudiosos que propõe edifícios com energia zero sob a perspectiva do ciclo de vida, pois muitas vezes os edifícios com baixo consumo de energia durante sua vida útil utilizam materiais de construção com alta energia incorporada, o que faz com que o balanço final do ciclo de vida não se aproxime do desejável.

Quando se trata de países em desenvolvimento os impactos relacionados à extração e produção de materiais e componentes da CPIC tendem a ser maiores devido à maior demanda por habitações e infraestrutura (KHUN, 2006).

Especificamente sobre os impactos causados pelos materiais de construção no Brasil, a extração de matéria prima prejudica biomas importantes, diversos materiais como cerâmica, cimento e todos os metais dependem de processos térmicos que utilizam combustíveis fósseis ou madeira extraída de forma ilegal. Alguns materiais liberam substâncias toxicas durante seu uso e seu descarte (CBCS,2009).

A grande informalidade no setor de produção de materiais de construção é outro problema frequente no Brasil. Empresas informais, além de sonegar impostos, desrespeitam as legislações ambientais e trabalhistas, e as normas técnicas nacionais e internacionais. A produção informal de alguns materiais chega a ultrapassar $50 \%$ do 
total, o que gera grande dificuldade para produção de dados confiáveis e o alcance da ecoeficiência (CBCS, 2009).

Por outro lado, segundo a Associação Brasileira da Indústria de Materiais de Construção (Abramat), em 2009 a CPIC representava 8,3\% do Produto Interno Bruto (PIB) brasileiro e empregava mais de 10 milhões de pessoas. Informações do Instituto Brasileiro de Geografia e Estatística (IBGE) mostram que em 2010 a CPIC foi responsável por um crescimento de $11,6 \%$ em seu PIB setorial e pela geração de mais de 329 mil vagas formais no mercado de trabalho. Estes dados demonstram a extrema importância da CPIC na economia do país.

Neste contexto, o desafio da atualidade é manter o desenvolvimento do setor da construção considerando, mediante a grande parcela de a responsabilidade que a CPIC tem na degradação do meio ambiente, medidas que minimizem seus impactos.

Em 1994 surge o conceito de Construção Sustentável que aplicou importantes princípios: "a criação e manutenção responsáveis de um ambiente construído saudável, baseado na utilização eficiente de recursos e no projeto baseado em princípios ecológicos" que lista sete princípios (TORGAL E JALALI, 2010 apud KIBERT, 2008) listados abaixo e representados na Figura 5:

- A redução do consumo de recursos;

- A reutilização de recursos;

- Utilização de recursos recicláveis;

- Proteção da natureza;

- Eliminação de tóxicos;

- Aplicação de avaliações de ciclo de vida em termos econômicos;

- Ênfase na qualidade. 


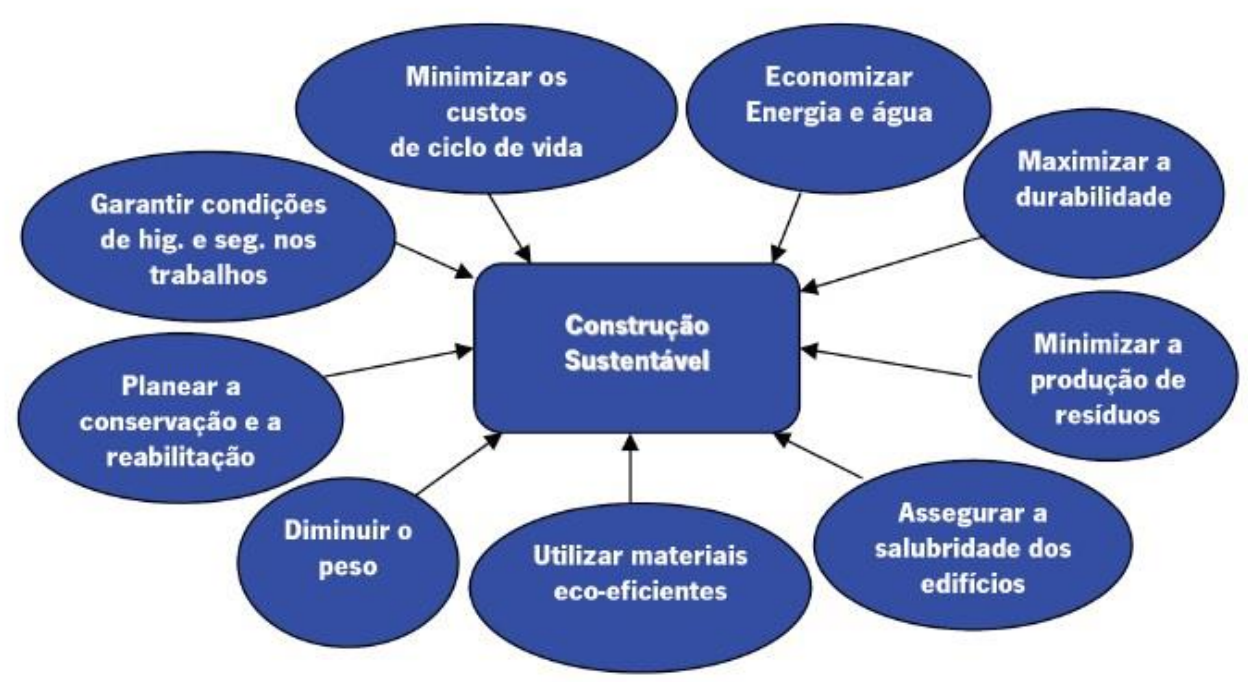

Figura 4: Prioridades a considerar no projeto para uma construção sustentável (TORGAL E JALALI, 2010 APUD MATEUS, 2008).

Este conceito evoluiu diante das diferenças de contexto existentes principalmente entre países desenvolvidos e países em desenvolvimento, passando a englobar a dimensão social da construção, considerando características como densidade demográfica, desenvolvimento econômico, padrão de vida da população, clima e matriz energética passou a incluir entre seus princípios a igualdade social, a preservação cultural, além de pré-requisitos econômicos (KHUN, 2006 apud INTERNATIONAL COUNCIL FOR RESEARCH AND INNOVATION IN BUILDING AND CONSTRUCTION, 1999).

Segundo Santos et al (2011) apud Rocha e Cheriaf (2003), o segmento de materiais e componentes da construção foi o que melhor se adaptou à aplicação dos conceitos de sustentabilidade pois a realização de ACV dos materiais utilizados na CPIC e de seus produtos, e a possibilidade de comparação de desempenhos ambientais se apresentam como uma ferramenta de auxílio na busca de uma indústria da construção ambientalmente mais eficiente. A Figura 6 ilustra a evolução do conceito de construção sustentável. 


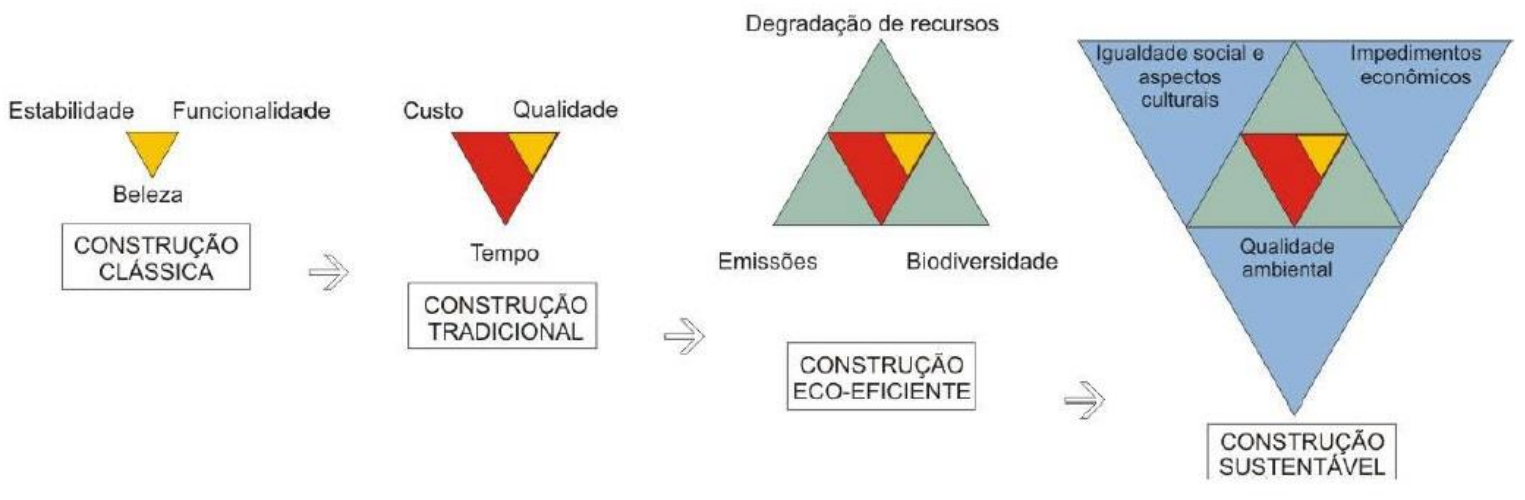

Figura 5: Inserção e desenvolvimento do conceito de sustentabilidade na construção (KHUN,2006 apud INTERNATIONAL COUNCIL FOR RESEARCH AND INNOVATION IN BUILDING AND CONSTRUCTION, 1999).

As decisões tomadas no processo de projeto, como a escolha, por meio das EPDs, de materiais que representam menor impacto ambiental, são as que possibilitam melhor resultado no desempenho do edifício durante toda a sua vida útil (BUENO et al, 2011).

No Brasil os estudos sobre ACV na construção civil avançam, mas Helpa e Soares (2011) concluem em um levantamento realizado em 2011 que o número de estudos é baixo, o que tem como consequência a carência de dados sobre materiais básicos utilizados na composição de materiais de construção e componentes.

$\mathrm{Na}$ falta de banco de dados nacionais as ACVs em produtos da construção realizadas no Brasil utilizam banco de dados internacionais, o que distancia os resultados da realidade. Para minimizar este problema o IBICT desenvolveu em 2005, em parceria com universidades brasileiras, um projeto de capacitação e transferência de tecnologia para a construção de um banco de dados nacional (HELPA; SOARES, 2011).

\subsection{Estudos de ACV na CPIC}

Para que seja possível a especificação de materiais mais eficientes do ponto de vista ambiental, é preciso que ferramentas como a ACV, de avaliação de desempenho ambiental, sejam aplicadas e os resultados sejam divulgados para ser possível a comparação de materiais e de sistemas utilizados na CPIC.

Ainda, as ferramentas devem ser aplicadas para auxiliar pesquisadores no desenvolvimento de novos materiais de construção com menor energia incorporada. 
Muitas vezes a alteração de alguma matéria prima na fórmula do componente pode trazer resultados animadores.

Estudos em diversos países estão focados na redução dos impactos da CPIC com o auxílio da ferramenta da ACV e estão obtendo resultados interessantes.

Estes artigos são encontrados em páginas de instituições de pequisas na internet. Os artigos consultados para este estudo foram encontrados na página da Coordenação de Aperfeiçoamento de Pessoal de Nível Superior (Capes) pela ferramenta de busca na página de periódicos utilizando as palavras-chave: ACV, materials construction, modern methods of construction, sustainability construction industry. Acesso em dezembro de 2014.

Por meio da comparação entre o desempenho de materiais diferentes, ou pela inserção de um componente diferente na fórmula de materiais de construção, ou pelo desenvolvimento de métodos com características específicas para a elaboração da $\mathrm{ACV}$, os estudos científicos contribuem com alternativas e possibilidades para 0 desenvolvimento do tema na CPIC.

Eles tratam do funcionamento da ferramenta ACV, dos impactos dos materiais de construção, comentam sobre bancos de dados disponíveis, sobre diferenças regionais e apontam oportunidades para que mais estudos sejam desenvolvidos.

Seus resultados concluem sobre a comparação de materiais, sobre as maiores categorias de impactos dos produtos avaliados, sobre a eficiência de ferramentas e métodos propostos, sobre os benefícios da ACV para a construção civil e sobre processos específicos, como a reciclagem. Muitos propõe alternativas de intervenção nos pontos críticos para melhorar o desempenho do produto, método, ferramenta ou processo avaliado.

A tabela presente no anexo 1 lista alguns artigos publicados nos últimos dez anos sobre ACV na indústria da construção. Muitos estudos são comparativos entre materiais de construção e sistemas construtivos e a maioria focados na avaliação da energia incorporada e nas emissões de gases do efeito estufa.

A Tabela 1 classifica os artigos de acordo com a abordagem do tema, o país e o ano de publicação. Identifica se trata-se de uma comparação entre resultados de 
ACVs de materiais de construção, ou se trata-se de aplicação em um estudo de caso, ou se trata-se do conceito e do estado da arte da ACV, entre outras abordagens.

Tabela 1: Relação dos artigos segundo abordagem do tema, país e ano de publicação.

\begin{tabular}{|c|c|c|c|}
\hline ABORDAGEM DO TEMA & LOCAL & ANO & QUANTIDADE \\
\hline $\begin{array}{l}\text { ACV comparativa entre materiais } \\
\text { ou componentes de construção }\end{array}$ & EUA & 2005 & 03 \\
\hline $\begin{array}{l}\text { ACV comparativa entre materiais } \\
\text { ou componentes de construção }\end{array}$ & Japão & 2006 & 01 \\
\hline $\begin{array}{l}\text { Relação entre ciclo de vida, } \\
\text { sustentabilidade e durabilidade }\end{array}$ & Espanha & 2007 & 01 \\
\hline $\begin{array}{l}\text { Identificação de materiais com } \\
\text { menor impacto no ciclo de vida }\end{array}$ & Israel & 2007 & 01 \\
\hline $\begin{array}{l}\text { ACV comparativa entre materiais } \\
\text { ou componentes de construção }\end{array}$ & China & 2008 & 01 \\
\hline $\begin{array}{l}\text { Estudo de caso - aplicação de } \\
\text { ACV }\end{array}$ & Portugal & 2008 & 01 \\
\hline $\begin{array}{l}\text { Estudo de caso - aplicação de } \\
\text { ACV }\end{array}$ & Tailândia & 2009 & 01 \\
\hline $\begin{array}{l}\text { ACV comparativa entre materiais } \\
\text { ou componentes de construção }\end{array}$ & $\begin{array}{l}\text { Reino } \\
\text { Unido }\end{array}$ & 2011 & 01 \\
\hline $\begin{array}{c}\text { Estudo de caso - aplicação de } \\
\text { ACV }\end{array}$ & França & 2011 & 01 \\
\hline $\begin{array}{l}\text { ACV comparativa entre materiais } \\
\text { ou componentes de construção }\end{array}$ & Itália & 2011 & 01 \\
\hline $\begin{array}{l}\text { Conceito e Estado da Arte da } \\
\text { ACV }\end{array}$ & Brasil & 2011 & 02 \\
\hline $\begin{array}{l}\text { Estudo de caso - aplicação de } \\
\text { ACV }\end{array}$ & Bélgica & 2012 & 01 \\
\hline $\begin{array}{l}\text { Estudo de caso - aplicação de } \\
\text { ACV }\end{array}$ & China & 2012 & 01 \\
\hline $\begin{array}{l}\text { Estudo de caso - aplicação de } \\
\text { ACV }\end{array}$ & Austrália & 2014 & 01 \\
\hline
\end{tabular}


A Tabela 2 esclarece quantos destes artigos estão relacionados às abordagens identificadas.

Tabela 2: Quantidade dos artigos segundo abordagem do tema

\begin{tabular}{|c|c|}
\hline ABORDAGEM DO TEMA & QUANTIDADE \\
\hline $\begin{array}{l}\text { ACV comparativa entre materiais ou } \\
\text { componentes de construção }\end{array}$ & 05 \\
\hline Estudo de caso - aplicação de ACV & 06 \\
\hline Conceito e Estado da Arte da ACV & 01 \\
\hline $\begin{array}{l}\text { Relação entre ciclo de vida, } \\
\text { sustentabilidade e durabilidade }\end{array}$ & 01 \\
\hline $\begin{array}{l}\text { Identificação de materiais com menor } \\
\text { impacto no ciclo de vida }\end{array}$ & 01 \\
\hline
\end{tabular}

\subsection{Sintese Analítica}

Tendo em vista os assuntos tratados neste capítulo pode identificar a importância da ACV para auxiliar na redução dos impactos ambientais da indústria da construção:

- A ACV é uma ferramenta de análise dos impactos ambientais de um determinado produto ao longo do seu ciclo de vida que permite quantificar a energia incorporada dos materiais;

- Os impactos causados pela CPIC ao meio ambiente são imensos;

- O processo produtivo de materiais de construção representa uma grande parcela dos impactos atribuídos à CPIC;

Ainda, podemos observar que vários estudos estão sendo feitos no sentido de utilizar a ACV para a avaliação de materiais e produtos da CPIC com o objetivo de compará-los e possibilitar a melhor opção na fase de especificação.

Estes estudos contribuem com o desenvolvimento de outras pesquisas e contribuíram nesta pesquisa com exemplos de como ACVs são aplicadas, com o esclarecimento sobre quais abordagens são tratadas com mais frequência, sobre quais resultados buscar, sobre a maneira de tratar os resultados e compará-los, e com as sugestões de melhorias nos produtos avaliados. 


\section{Capítulo 2: Painel Pré-Moldado de Blocos Cerâmicos e}

\section{Concreto.}

A habitação é uma necessidade básica do ser humano. No contexto da cidade, o conceito de habitação se tornou mais do que a moradia, incluindo a inserção no contexto urbano e o acesso à infraestrutura urbana que engloba saneamento ambiental, mobilidade e transporte coletivo, equipamentos e serviços urbanos e sociais, buscando garantir o direito à cidade (MINISTÉRIO DAS CIDADES, 2004).

O Ministério das Cidades, em relatório publicado em 2011, identifica que em 2008 o déficit habitacional do país correspondia a 5.546 milhões de domicílios, dos quais 4.629 milhões, ou 83,5\% localizam-se em áreas urbanas. Isso corresponde a 9,6\% dos domicílios particulares do país, sendo 9,4\% nas áreas urbanas e $11 \%$ nas áreas rurais (Ministério das Cidades, 2011).

No DF o déficit habitacional correspondia a 103.896 domicílios, o que representa 13,9\% dos domicílios particulares (Ministério das Cidades, 2011).

Segundo este relatório o conceito de déficit habitacional está ligado às deficiências do estoque de moradias, englobando as moradias sem condições de serem habitadas devido à construção precária e ao desgaste da estrutura física, as famílias que coabitam por falta de condições de terem outra moradia, os locatários de baixa renda com dificuldade de pagar o aluguel e os locatários que vivem em moradias com grande densidade (Ministério das Cidades, 2011).

A Fundação João Pinheiro (1995) apresenta ainda, além do déficit habitacional, o conceito de demanda demográfica que considera a necessidade de habitações resultante do aumento populacional (SOARES et al, 2006)

Dentro deste contexto a Política Nacional de Habitação (2004) visa suprir este déficit e tem como principal objetivo garantir à população, principalmente de baixa renda, o acesso à habitação digna.

A habitação digna deve proporcionar, além de uma construção durável e confortável, o acesso à infraestrutura urbana, equipamentos e serviços urbanos e sociais, pois a habitação "significa mais que o objeto construído, significa uma integração entre fatores arquitetônicos, culturais, econômicos, sócio demográficos, 
psicológicos e políticos que mudam com o passar do tempo" (BRANDÃO; HEINECH. 2003 apud LAWRENCE, 1987,1990).

Para cumprir a meta de sanar o déficit habitacional o governo federal lançou em 2009 o Programa Minha Casa Minha Vida (PMCMV) que em parceria com os estados, municípios, empresas e entidades sem fins lucrativos, auxilia a construção e o financiamento da casa própria para famílias com renda bruta mensal de até $\mathrm{R} \$ 5.000,00$ (http://www.caixa.gov.br/habitacao/mcmv/).

Com o crescimento da economia e o incentivo do programa PMCMV a construção de conjuntos habitacionais, caracterizados por moradias construídas em série e em grande quantidade, se multiplicou pelo país. A busca por rapidez e padronização abriu espaço para novas tecnologias de construção, que na maioria das vezes se caracterizam por elementos pré-fabricados, produzidos em série e montados no canteiro de obras.

Estes processos defendem a racionalização da construção gerando menor desperdício de material, e consequente menor geração de resíduos, menor tempo de implementação e maior padronização e qualidade do produto final. Estima-se que a redução do desperdício no processo de pré-fabricação está entre $20 \%$ e 40\% (MONAHAN; POWELL 2011, apud WRAP 2008).

A eficiência no processo construtivo que estes métodos racionalizados buscam alcançar contribuem com a diminuição da energia incorporada durante a fase de construção. Estudos sugerem que de $2 \%$ a $36 \%$ da energia incorporada de uma casa construída nos métodos tradicionais é atribuída às matérias primas, produção de materiais de construção, construção da casa e transporte de materiais (MONAHAN; POWELL 2011).

Uma das novas tecnologias já avaliadas pelo SINAT (Sistema Nacional de Avaliação Técnica de produtos) e aceitas pelo PMCMV é a de casas montadas com painéis de tijolos cerâmicos e concreto armado pré-fabricados no canteiro de obras, denominado Casa Express. Este sistema está sendo usado pela primeira vez no Distrito Federal na construção de habitações populares na Região Administrativa do Riacho Fundo II.

O sistema construtivo de alvenaria teve um espaço muito grande durante séculos na história da arquitetura principalmente por poder ser fabricada com 
diferentes componentes, por ser um sistema de fácil execução e adaptação à diferentes sítios, tipologias e sistemas de produção das edificações (ZANONE; SÁNCHEZ, 2012).

A cerâmica é utilizada pelo homem para a construção há muito tempo, precedida somente pela pedra e pela madeira. É um material de fácil acesso em qualquer parte do mundo, facilmente moldável e com elevada resistência mecânica atingida no processo de cozimento (OLIVEIRA, 2005 apud ZANONE; SÁNCHEZ, 2012).

Segundo Zanone e Sánchez (2012), os painéis pré-fabricados começam a ser utilizados com a Revolução Industrial, mas as pesquisas para o seu desenvolvimento e viabilização da sua utilização ocorre principalmente a partir dos anos 50 do século $\mathrm{XX}$.

Inicialmente os painéis pré-fabricados não foram capazes de competir com a forma tradicional de se construir alvenaria, mas com o passar do tempo e o desenvolvimento da economia a mão de obra para este serviço foi ficando escassa e cara.

Ainda, o aumento da população provocou o aumento da demanda por construções e a necessidade de rapidez em seu atendimento. Com isso os painéis pré-fabricados ganharam espaço no mercado da construção.

Para Sabbatini (1998), a forma tradicional de construção de alvenarias no Brasil é artesanal, sua qualidade depende da competência do executor que tem a liberdade de tomar decisões importantes durante a construção do produto, situação que compromete o padrão de qualidade das construções. Este método construtivo tradicional da alvenaria tem sido questionado e considerado um dos responsáveis pelo atraso tecnológico do setor da construção civil no Brasil (SABBATINI, 1998).

Já o sistema de painéis pré-fabricados de cerâmica tem sido utilizado com sucesso em países da Europa e nos Estados Unidos, apresentando os benefícios de conservar as vantagens funcionais e estéticas das construções em alvenaria tradicional e de eliminar alguns problemas apresentado por ele como perda de tempo devido às chuvas, dificuldade de estocagem de materiais, dificuldades no controle de qualidade e diminuição de mão de obra (CÉSAR et al, 2006). 
No Brasil, o sistema de construção tradicional de alvenaria que utiliza tijolos cerâmicos ainda é muito difundido. A alvenaria pode ser autoportante ou combinada com estrutura de concreto armado, e coberta com telhado, que pode ser de barro, concreto, cimento, etc.

Com o crescimento da indústria da construção, da habitação coletiva e dos conjuntos habitacionais as os sistemas construtivos inovadores, como os painéis préfabricados de cerâmica, que prometem padronização da qualidade, minimização da necessidade de mão de obra e rapidez na construção ganharam espaço no mercado.

Um sistema construtivo inovador é aquele que ainda não possui uma norma técnica brasileira para amparar o seu uso e precisa de avaliações que proporcionem credibilidade e reconhecimento perante os consumidores e agentes financiadores (ZANONE; SÁNCHEZ, 2012).

No Brasil existe o SINAT (Sistema Nacional de Avaliação Técnica de produtos) criado em 2007 no âmbito do PBQP-H (Programa Brasileiro de Qualidade e Produtividade do Habitat), do Ministério das Cidades (MC) que valida novas alternativas tecnológicas para produtos e processos inovadores da construção civil no Brasil.

O SINAT elabora diretrizes para a avaliação técnica de uma determinada família de produtos. Para sistemas construtivos inovadores existem cinco diretrizes conforme Tabela 3 apresentada por Zanone (2012):

Tabela 3: Diretriz do SINAT sobre sistemas construtivos.Fonte: Zanone e Sanchez

\begin{tabular}{|c|c|c|}
\hline $\begin{array}{l}\text { Diretriz SINAT nº } 001 \\
\text { - Revisão } 02\end{array}$ & $\begin{array}{l}\text { Diretriz para Avaliação Técnica de sistemas } \\
\text { construtivos em paredes de concreto armado } \\
\text { moldadas no local. }\end{array}$ & $\begin{array}{l}\text { Julho } 2009 \\
\text { rev. } 02- \\
\text { agosto } 2011\end{array}$ \\
\hline Diretriz SINAT $n^{\circ} 002$ & $\begin{array}{l}\text { Diretriz para Avaliação Técnica de sistemas } \\
\text { construtivos integrados por painéis estruturais } \\
\text { pré-moldados, para emprego em casas } \\
\text { térreas, sobrados e edifícios habitacionais de } \\
\text { múltiplos pavimentos. }\end{array}$ & $\begin{array}{l}\text { Novembro } \\
\text { de } 2009\end{array}$ \\
\hline Diretriz SINAT nº03 & $\begin{array}{l}\text { Diretriz para Avaliação Técnica de sistemas } \\
\text { construtivos estruturados em painéis leves de } \\
\text { aço conformados a frio, com fechamentos em } \\
\text { chapas delgadas (Sistemas leves tipo "Light } \\
\text { Steel Framing"). }\end{array}$ & $\begin{array}{l}\text { Abril } \\
2010\end{array}$ \\
\hline Diretriz SINAT nº 004 & $\begin{array}{l}\text { Diretriz para Avaliação Técnica de sistemas } \\
\text { construtivos formados por paredes estruturais } \\
\text { construídas de painéis de PVC preenchidos }\end{array}$ & $\begin{array}{l}\text { Setembro } \\
\text { de } 2010\end{array}$ \\
\hline
\end{tabular}




\begin{tabular}{|l|l|l|}
\hline & $\begin{array}{l}\text { com concreto (Sistemas de paredes com } \\
\text { formas de PVC incorporadas). }\end{array}$ & \\
\hline Diretriz SINAT n ${ }^{\circ} 005$ & $\begin{array}{l}\text { Diretriz para Avaliação Técnica de sistemas } \\
\text { construtivos estruturados em peças de } \\
\text { madeira maciça serrada com fechamentos } \\
\text { em chapas delgadas (Sistemas leves tipo } \\
\text { "Light Wood Framing). }\end{array}$ & de 2011 \\
\hline
\end{tabular}

As diretrizes da tabela 04 falam sobre os painéis de blocos cerâmicos especificamente:

Tabela 4: Diretriz do SINAT sobre o CASA EXPRESS.Fonte: Zanone e Sanchez

\begin{tabular}{|l|l|l|}
\hline Diretriz SINAT $n^{\circ} 002$ & $\begin{array}{l}\text { Diretriz para Avaliação Técnica de sistemas } \\
\text { construtivos integrados por painéis estruturais } \\
\text { pré-moldados, para emprego em casas } \\
\text { térreas, sobrados e edifícios habitacionais de } \\
\text { múltiplos pavimentos. }\end{array}$ & $\begin{array}{l}\text { Novembro } \\
\text { de } 2009\end{array}$ \\
\hline DATec $\mathrm{n}^{\circ} 008$ & $\begin{array}{l}\text { Sistema JET CASA de painéis pré-moldados } \\
\text { mistos de concreto armado e blocos } \\
\text { cerâmicos para paredes. }\end{array}$ & $\begin{array}{l}\text { Novembro } \\
\text { de } 2011\end{array}$ \\
\hline DATec $\mathrm{n}^{\circ} 009$ & $\begin{array}{l}\text { Sistema CASA EXPRESS de painéis pré- } \\
\text { moldados mistos de concreto armado blocos } \\
\text { cerâmicos para paredes. }\end{array}$ & $\begin{array}{l}\text { Novembro } \\
\text { de } 2012\end{array}$ \\
\hline
\end{tabular}

Quando o fabricante propõe um produto inovador que se insere dentro de umas das diretrizes do SINAT ele pede a elaboração de uma Datec, que é um documento síntese de divulgação dos resultados da avaliação técnica do produto, realizada por uma instituição técnica avaliadora autorizada a participar do SINAT, com base na metodologia determinada pela Diretriz (ZANONE; SÁNCHEZ, 2012).

O sistema Casa Express, composto de painéis estruturais de blocos cerâmicos e concreto armado montados no canteiro de obras, insere-se na Diretriz SINAT no 002 de novembro de 2009, Datec 009 de fevereiro de 2012.

O sistema construtivo com blocos cerâmicos tem vantagens como a de conservar a aparência da alvenaria tradicional amplamente aceita pelo usuário; contribuir com empregos formais, o que aumenta a qualidade da mão de obra; contribuir com o desenvolvimento da indústria cerâmica (CÉSAR; ROMAN, 2006).

A interação entre os agentes (projetistas, construtores e fornecedores) que o sistema industrializado necessita desde a fase de projeto proporciona uma melhor 
gestão do processo e a aplicação de soluções e detalhes construtivos de maior complexidade, com o intuito de facilitar o processo final de construção.

\subsection{O Sistema Casa Express}

O Casa Express é um sistema construtivo de painéis estruturados prémoldados de blocos cerâmicos e concreto armado desenvolvido pela construtora Casa Express, sediada em Itapira - SP, que de acordo com informações em sua página na internet, trabalha com pesquisas e desenvolvimento de novas tecnologias construtivas desde 1997, data de sua fundação.

O sistema conquistou em 2012 o primeiro lugar no Prêmio CBIC de Inovação e Sustentabilidade na categoria sistemas construtivos e em 2014 foi destacado no Prêmio Téchne - Inovação Tecnológica na Construção Civil na categoria Produtos/Sistemas (http://www.casaexpress.ind.br/voce/certificacoes.shtml).

Este método está sendo usado para a construção de aproximadamente 400 casas populares no DF, na Região Administrativa do Riacho Fundo II (RA XXI).

\section{2 projeto das casas}

Conforme observado no canteiro de obras, a construção das casas é feita mediante projeto específico enviado pela empresa Casa Express em um caderno contendo todo o detalhamento dos painéis que vão formar cada parede da casa, com suas aberturas de portas e janelas, e com as passagens de tubulações elétricas e hidráulicas. O conjunto de painéis e lajes maciças que irão formar a casa são denominados kits.

O primeiro desenho do caderno de projetos é a planta da casa com as cotas das paredes, a dimensão das aberturas, o layout proposto para o mobiliário, os pontos elétricos, e hidráulicos. Em seguida é apresentada uma planta só das paredes, formadas pelos painéis de concreto e blocos cerâmicos, com cotas e numeração dos painéis para indicação do detalhamento.

Posteriormente começam os desenhos dos painéis que formarão as paredes. Estes detalhamentos são formados por uma primeira vista onde constam as lajotas (blocos cerâmicos), os ganchos de içamento e as treliças, uma segunda vista com posicionamento e especificação da ferragem da primeira malha, uma terceira vista 
com posicionamento e especificação da barra de soldagem e da malha intermediária, e outra vista com posicionamento e especificação da malha superior.

Aberturas e tubulações, quando existentes, estão indicadas nas vistas correspondentes. A Figura 7 esquematiza a apresentação do projeto da casa e dos painéis.

\subsection{0 processo construtivo do painel}

Os painéis são montados no canteiro de obras, em um espaço destinado à linha de produção. Neste local são construídas pistas de alvenaria que servem de base para a montagem dos painéis.

Todo o processo de montagem segue o projeto detalhado conforme descrito anteriormente. Existe um encarregado por todo o processo de montagem dos painéis e das casas. Ele acompanha e orienta a montagem dos painéis de acordo com o projeto e toma as decisões sobre a produção.

Os demais trabalhadores são executores que seguem as orientações montando as formas, produzindo o cimento concreto, colocando cada elemento segundo a orientação do encarregado, transportando os painéis e construindo as casas.

A descrição a seguir foi baseada na visita à obra realizada em janeiro de 2013 quando foi realizado o acompanhamento da construção de uma parede.

As formas são de chapas de ferro dobradas, parafusadas umas às outras. Elas são montadas e posicionadas sequencialmente na pista.

Para início da montagem de um painel, as formas são besuntadas com óleo queimado e óleo diesel na proporção de 1:3 para evitar a aderência à forma ou à pista. Adiciona-se uma camada de $2 \mathrm{~cm}$ de concreto produzido na betoneira da obra com traço de 1:3:3. Nesta camada molda-se os cantos dos painéis para formar o encaixe com as paredes contíguas. 


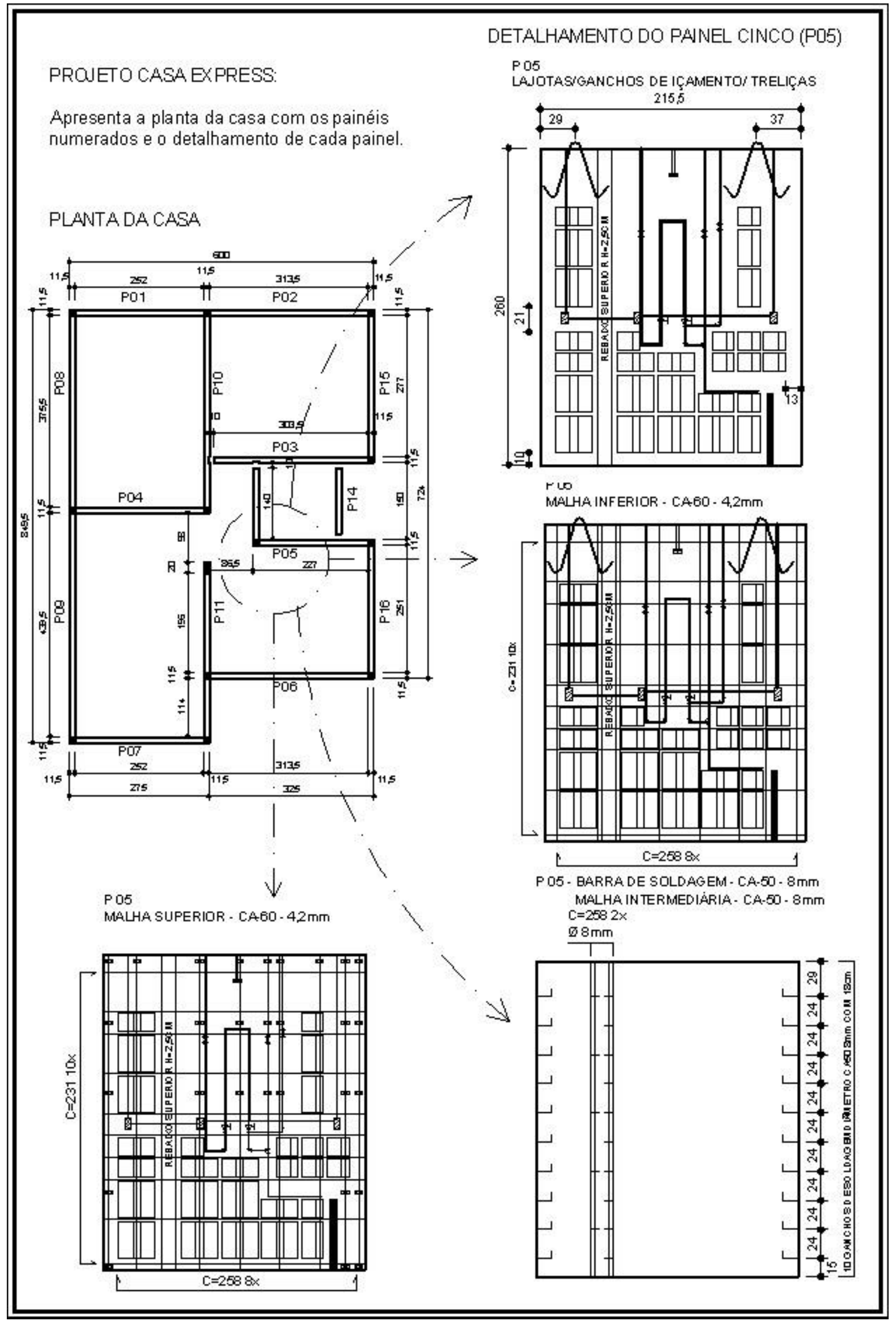

Figura 6: Projeto da casa com indicação dos painéis e detalhamento dos painéis. 
Colocam-se treliças de ferro nas extremidades laterais e esperas para içamento feitas de vergalhões dobrados. O centro é preenchido com os blocos cerâmicos que ficam distantes aproximadamente três centímetros um do outro, tanto no sentido horizontal quanto no sentido vertical, para a passagem dos vergalhões de ferro que são posicionados em seguida nos dois sentidos formando uma malha. Após esta etapa da ferragem são posicionados os conduítes, caixas elétricas e as tubulações hidro sanitárias quando previstas no projeto.

Então é aplicada mais uma camada de concreto, que mantém sempre o mesmo traço 1:3:3, que cobre a ferragem entre os blocos. Os blocos cerâmicos utilizados neste sistema tem um modelo especial, são fabricados sob projeto Eles contém vincos por onde passa uma segunda malha de ferro, mais superficial, que depois é coberta pela última camada de concreto, que dá acabamento à peça. São fabricados em Silvânia - GO e transportados de caminhão até o DF.

Segundo informações do encarregado da obra, as paredes devem ficar na pista aproximadamente 24 horas para a curagem do concreto, e então podem ser içadas e transportadas por um caminhão com guindaste, conhecido popularmente no Brasil como caminhão Munck, para o local da montagem da casa.

A Tabela 5 apresenta o processo de montagem do painel em imagens obtidas no canteiro de obras (Figuras 8,9,10,11).

\subsection{A construção da casa}

As casas são construídas num loteamento ao lado do canteiro onde estão as pistas de montagem dos painéis. As fundações são construídas de maneira tradicional, as vigas baldrames ficam à espera dos painéis que são apenas apoiados nesta estrutura.

Os painéis são içados e transportados por um caminhão munch, que auxilia no posicionamento dos painéis sobre as fundações. Cada painel tem um acabamento nas extremidades com esperas de ferro que são amarrados e concretados no local.

Nas casas construídas no DF são usadas lajes de concreto pré-moldadas e telhas de concreto. As platibandas são construídas com o mesmo processo de painéis de blocos cerâmicos, junto com as paredes (Tabela 6 - Figuras 12,13 e 14). 
Tabela 5: Imagens do processo de produção do painel.

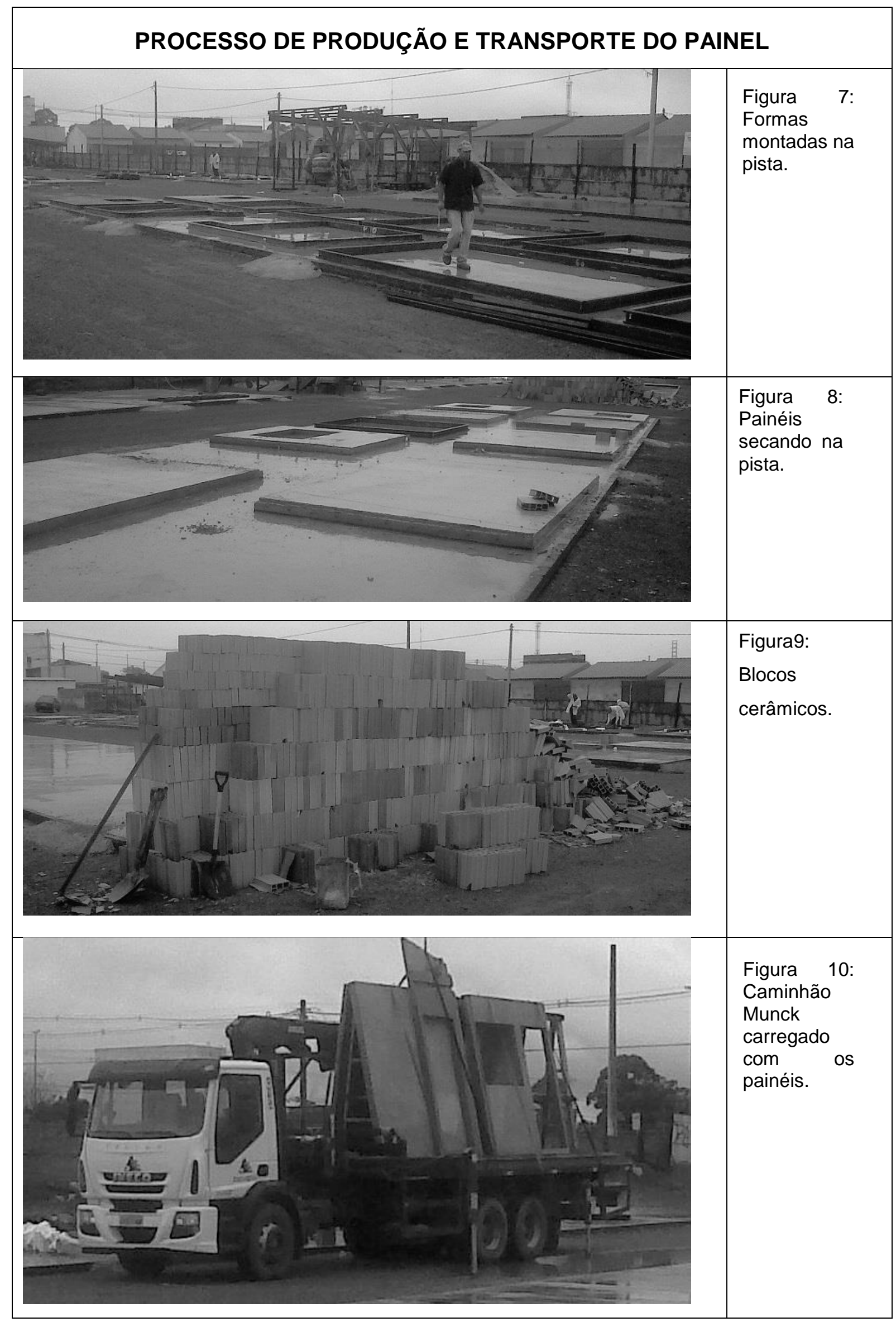


Tabela 6: Imagens da construção da casa.

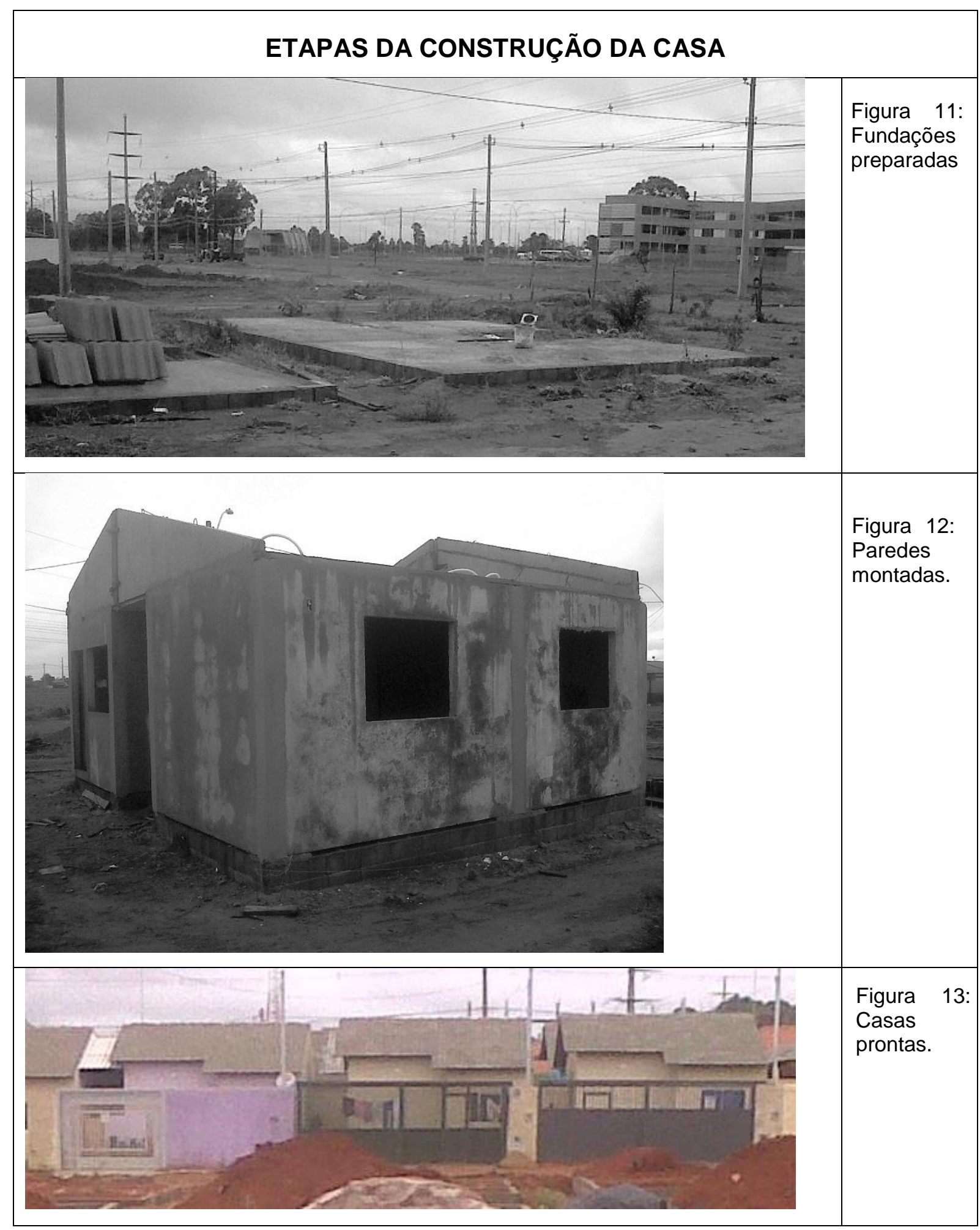


2.5 Esquema do processo produtivo

A Figura 15 abaixo esquematiza as etapas da construção do painel.

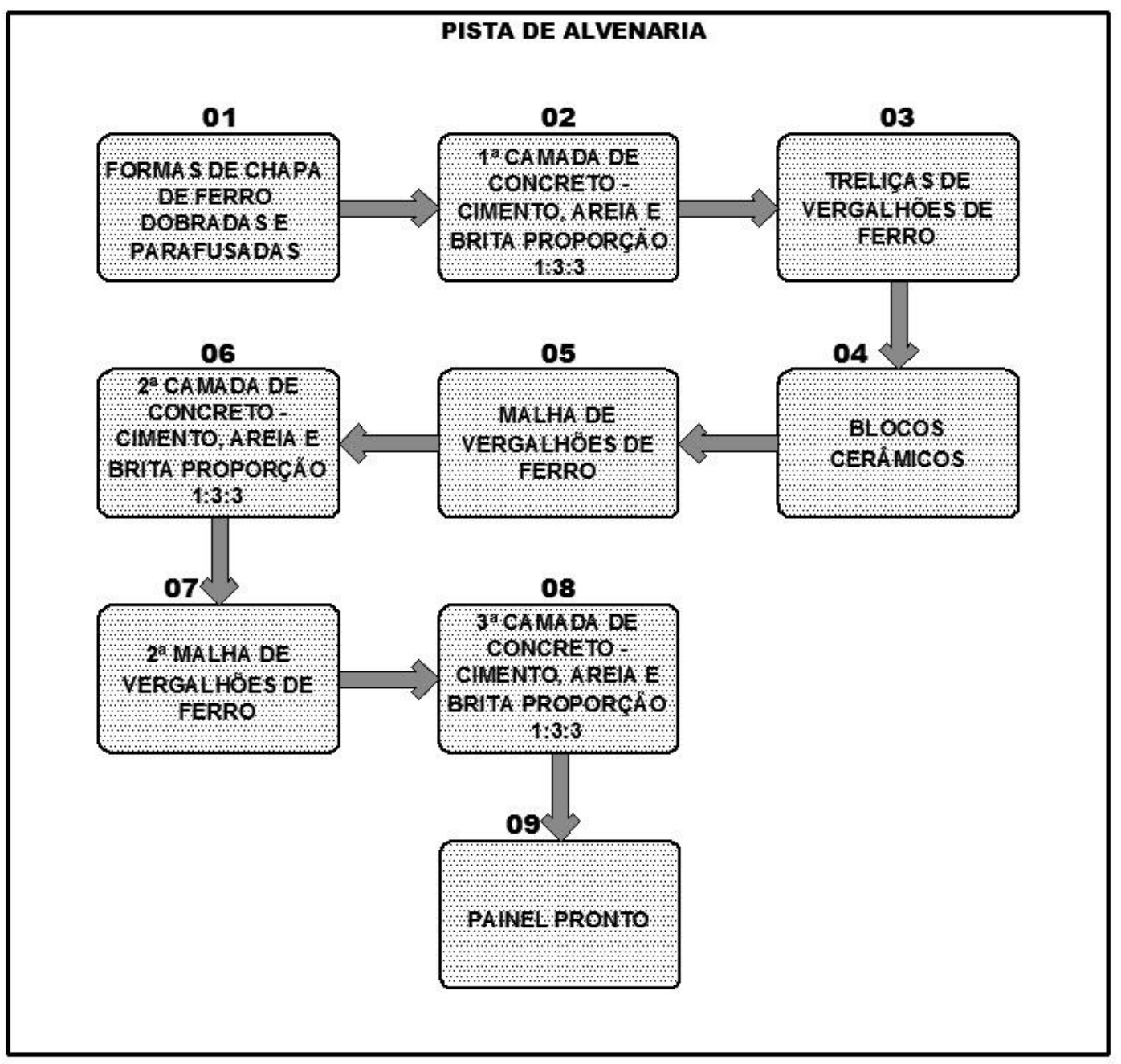

Figura 14: Esquema de montagem do painel.

A Tabela 7 apresenta algumas vantagens e desvantagens apresentadas pelo sistema construtivo composto de painel pré-fabricado de blocos cerâmicos, em relação à alvenaria convencional citadas por Cesar e Roman (2006):

Tabela 7: Vantagens e desvantagens dos sistemas construtivos pré-fabricados de blocos cerâmicos SISTEMAS CONSTRUTIVOS DE PAINÉIS PRÉ-FABRICADOS DE BLOCOS CERÂMICOS

\begin{tabular}{|c|c|}
\hline VANTAGENS & \multicolumn{3}{|c|}{ DESVANTAGENS } \\
\hline - Materiais duráveis; & $\begin{array}{l}\text { Escassez de mão de obra } \\
\text { treinada; }\end{array}$ \\
\hline
\end{tabular}


- Os painéis são uma composição de bloco cerâmico e concreto armado, materiais já difundidos e com eficiência conhecida no mercado da construção;

- Estes materiais têm desempenhos relacionados à conforto ambiental já conhecidos e aceitos;

- Técnica de fácil aprendizado;

- Rapidez na construção da casa;

- Sistema adaptável a qualquer projeto;

- Necessidade de menor número de mão de obra;

- Maior controle sobre as dimensões, os alinhamentos, encaixes, etc.;

- Redução de perdas e desperdícios;

- Painéis montados no canteiro de obras, o que evita problemas, gastos e impactos ambientais decorrentes do transporte do produto;

- Interação entre projetistas, construtores e fornecedores na fase do projeto possibilitando busca de melhores soluções;

- Possibilidade de soluções projetuais para possíveis ampliações, reformas e flexibilidade nas plantas oferecidas;

- Aparência de alvenaria convencional;
- Necessidade de um maior investimento inicial e de bastante espaço disponível já que precisa ser montada uma linha de produção de painéis no canteiro de obras;

- O bloco cerâmico é produzido sob medida para a construção da casa, o que pode encarecer 0 processo quando se trada de empreendimento de menor escala;

- Necessidade de um caminhão munch disponível na obra para transporte e içamento das placas;

- Alterações futuras limitadas às previsões do projeto;

- Falta de normalização;

\subsection{Síntese Analítica.}

Para a aplicação da ferramenta de avaliação de ciclo de vida é necessário conhecer detalhadamente o processo produtivo do produto a ser avaliado. Este capítulo apresenta com descrição e imagens o processo produtivo do painel de blocos 
cerâmicos e concreto armado: seu conceito de material inovador relevante para habitações de interesse social; seu projeto detalhado; e sua pré-fabricação no canteiro de obras. Com as informações aqui apresentadas é possível planejar o levantamento de dados necessário para a modelagem do inventário de ciclo de vida (ICV). 


\section{Capítulo 3: ACV: Aplicação da metodologia do ILCD no painel de bloco cerâmico e concreto.}

A ACV possui sua metodologia normatizada de acordo com a ISO 14.040 e 14.044 (ISO 2006a, ISO 2006b).

No Brasil a ferramenta ACV vem se desenvolvendo por meio do Programa Brasileiro de Avaliação de Ciclo de Vida (PBACV) que conta com o apoio do Ministério do Desenvolvimento, Indústria e Comércio Exterior (MDIC), o Ministério da Ciência, Tecnologia e Inovação (MCTI), o Instituto Nacional de Metrologia, Qualidade e Tecnologia (Inmetro), o Instituto Brasileiro de Informação, Ciência e Tecnologia (IBICT), a academia e instituições representantes de setores da economia.

As normas ISO 14040 e 14044 fornecem um guia indispensável para a realização de uma $A C V$, mas deixam grandes brechas para que os aplicadores tomem decisões individuais. Apesar da flexibilidade no processo ser necessária por englobar produtos e situações muito diferentes, a falta de uma normatização mais abrangente, que diminua o poder de decisão individual do aplicador, pode afetar a credibilidade dos resultados (EUROPEAN COMISSION - Provisions and Action Steps, 2010).

Neste contexto diversas metodologias mais detalhadas, baseadas nas normas ISO 14040 e 14044, foram criadas para guiar o processo de aplicação da ferramenta de ACV, entre elas o Manual do International Reference Life Cicle Data System (ILCD), uma iniciativa da Comissão Europeia de Produção e Consumo Sustentável e Plano de Ação Sustentável em Política Industrial (COM(2008)397).

O PBACV definiu a metodologia do ILCD como a metodologia padrão para a realização da ACV na Brasil. Segundo o relatório da Oficina 2: GT Construção do PBACV - Avaliação de Ciclo de Vida (2012), o processo europeu demonstrou que a metodologia do ILCD é a mais harmonizada no sentido de atender a diferentes objetivos e a ISO 14000.

O Manual ILCD consiste em uma série de documentos técnicos que orientam a prática da ACV na indústria e no governo. Estes documentos cobrem todos os passos necessários para a realização de qualquer tipo de $A C V$, incluindo a coleta e modelagem dos dados necessários para cada avaliação. A figura 21 ilustra o esquema de realização de uma ACV segundo o ILCD (WOLF et al,2012). 


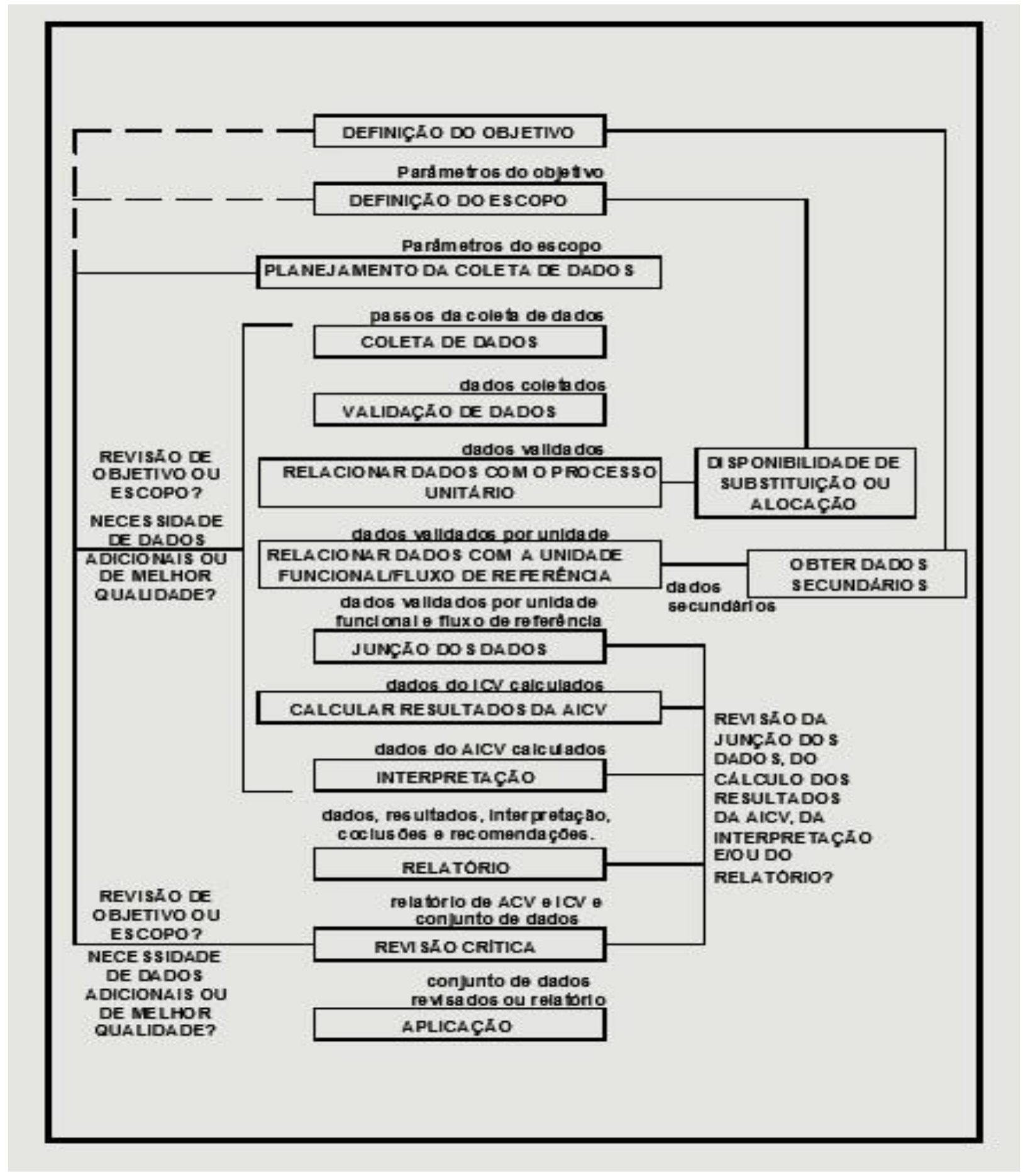

Figura 15: Esquema de aplicação da ACV segundo o ILCD. Fonte WOLF et al, 2012.

O objetivo é que seja utilizado como um documento primário que ajuda no desenvolvimento de critérios, guias e ferramentas para uma aplicação específica em setores específicos da indústria, num grupo específico de produtos. Ele define que tipo de revisão é necessário, identifica o uso da nomenclatura e estabelece requisitos para a escolha do método de avaliação de impacto a ser utilizado (WOLF et al, 2012) 
Qualquer organização pode elaborar seus guias específicos, desde que um painel de revisão independente conclua que eles estão de acordo com a metodologia do ILCD eles complementarão, em cada caso, o manual ILCD (WOLF et al,2012).

Para a elaboração da ACV no painel de blocos cerâmicos e concreto apresentada neste trabalho o manual do ILCD foi estudado e a partir dele foi elaborado um questionário sobre as fases recomendadas. O questionário serve de guia para a elaboração do estudo e poderá servir também como referência para validar outros estudos em relação à metodologia do ILCD.

\subsection{Fase de Definição de Objetivo.}

A primeira fase da ACV de qualquer processo ou produto é a definição do objetivo do estudo. Nesta fase são definidos o contexto de decisão, as intenções de aplicação do estudo e o público alvo (WOLF et al, 2012).

A Tabela 8 representa o resumo dos passos propostos pela metodologia do ILCD para a fase de objetivo. Ela foi derivada do questionário anexo (Anexo I) e orienta a construção desta fase do estudo.

A definição do objetivo guia a elaboração do escopo e o controle de qualidade do estudo pois os passos são tomados em vista das definições desta fase (WOLF et al, 2012).

O objeto deste estudo de ACV é o painel de blocos cerâmicos e concreto apresentado no capítulo anterior. A intenção é que o resultado do estudo quantifique os impactos ambientais da construção do painel, conforme categorias definidas no decorrer do estudo.

Tabela 8: Tabela dos passos pedidos pelo ILCD - Fase de Objetivo. Fonte: EUROPEAN COMMISSION, 2010.

\begin{tabular}{|l|l|l|}
\hline $\begin{array}{l}\text { Perguntas segundo metodologia do } \\
\text { ILCD }\end{array}$ & $\begin{array}{l}\text { Respostas referentes ao painel } \\
\text { avaliado }\end{array}$
\end{tabular}

FASE DE OBJETIVO 


\begin{tabular}{|l|l|}
\hline Qual será a aplicação do estudo? & $\begin{array}{l}\text { Quantificar os impactos ambientais da } \\
\text { montagem do painel de blocos } \\
\text { cerâmicos e concreto armado. }\end{array}$ \\
\hline $\begin{array}{l}\text { Quais as limitações do estudo? } \\
\text { (Dados assumidos, impactos } \\
\text { considerados e quais os passos } \\
\text { metodológicos?) }\end{array}$ & $\begin{array}{l}\text { Os limites do sistema serão da extração } \\
\text { de materiais até a saída do painel na } \\
\text { fábrica. Serão usados dados primários e } \\
\text { secundários. Serão seguidos os passos } \\
\text { metodológicos propostos no manual do } \\
\text { ILCD. }\end{array}$ \\
\hline $\begin{array}{l}\text { Quais as razões para a realização do } \\
\text { estudo? }\end{array}$ & $\begin{array}{l}\text { Estudar o processo de aplicação da } \\
\text { ferramenta ACV, concluir sobre a } \\
\text { utilização da metodologia do ILCD, } \\
\text { contribuir com a geração de dados. }\end{array}$ \\
\hline Quem é o público alvo? & $\begin{array}{l}\text { Academia, produtores de materiais de } \\
\text { construção, arquitetos, construtores e } \\
\text { CPIC em geral. }\end{array}$ \\
\hline $\begin{array}{l}\text { Qual tipo de divulgação será dada ao } \\
\text { estudo? (Interna, externa com } \\
\text { restrições ou pública?) }\end{array}$ & \begin{tabular}{l} 
Pública \\
\hline É um estudo comparativo?
\end{tabular} \\
\hline Quem são os atores? & $\begin{array}{l}\text { Construtores do Casa Express, ILCD, } \\
\text { academia. }\end{array}$ \\
\hline Qual será a aplicação dos resultados? & Banco de dados \\
\hline Qual será a aplicação do estudo? & $\begin{array}{l}\text { Quantificar os impactos ambientais da } \\
\text { montagem do painel de blocos } \\
\text { cerâmicos e concreto armado. }\end{array}$ \\
\hline
\end{tabular}

O estudo será limitado ao processo de produção do painel que acontece dentro do canteiro de obras, do momento em que os materiais entram pelo portão até quando os painéis saem para a montagem das casas.

O cálculo será feito pelo software Gabi 6 Educational da PE-International e os dados dos materiais como cimento, areia e outros serão retirados do seu banco de dados. Os dados do processo produtivo foram captados no canteiro de obras.

As razões para a realização do estudo englobam a geração de dados regionais sobre materiais e sistemas construtivos com o intuito de contribuir para a redução de impactos ambientais da CPIC; a realização de um estudo de ACV seguindo a metodologia proposta pelo ILCD para identificar possíveis dificuldades e contribuir para a busca de soluções; e a esquematização da aplicação da metodologia que pode facilitar futuras revisões de estudos de ACV. 
O público alvo deste estudo inclui arquitetos, engenheiros e a CPIC, que podem utilizá-lo como fonte de dados para a escolha de materiais e tecnologias construtivas. Inclui também a academia, pois contribui com os estudos de desenvolvimento da ACV. O tipo de divulgação será pública e não será um estudo comparativo. Os atores envolvidos são os construtores das casas que utilizam este sistema construtivo e a academia, ambiente onde o estudo está sendo realizado.

Os resultados poderão ser aplicados na formação de um banco de dados sobre impactos ambientais de materiais e sistemas construtivos conforme citado acima, contribuindo assim para escolhas conscientes na fase de especificação do projeto.

A metodologia do ILCD divide os estudos de ACV em três situações distintas de acordo com as possíveis consequências da divulgação do resultado do estudo.

- Situação $A$, quando os resultados não interferem de forma ampla e não trazem grandes consequências no contexto em que o produto está inserido;

- Situação $B$, quando, ao contrário da situação $A$, os resultados trazem grandes consequências;

- E situação C1 e C2, quando os resultados servem como registro de informação sem consequências adicionais.

Este estudo se enquadra na situação C.

\subsection{Fase de Definição do Escopo.}

A definição do escopo do estudo identifica e define em detalhes o objeto a ser estudado, em coerência com o objetivo definido. Define também sobre a metodologia, a qualidade a ser obtida, o relatório e a revisão (WOLF et al, 2012).

A metodologia para organização e planejamento do estudo é a proposta pelo ILCD. Depois de definidos os objetivos e o escopo inicia-se a fase de inventário de dados (ICV) quando os dados são coletados no canteiro de obras (dados primários) e no banco de dados do software $\mathrm{GaBi}$, da PE - International (dados secundários) onde o sistema é modelado e os resultados calculados. 
A metodologia do ILCD é uma metodologia consistente, definida pelo Programa Brasileiro de Avaliação de Ciclo de Vida (PBACV) como metodologia padrão para estudos de ACV no Brasil e o Software Gabi é um dos softwares utilizados internacionalmente para modelagem dos sistemas e cálculos de resultados (PBACV, 2014).

O software contém uma banco de dados disponibilizado com a versão estudantil e oferece a possibilidade de compra de outros banco de dados. Existe uma classificação de dados, identificando os considerados de boa qualidade.

Os dados considerados de boa qualidade são completos, contém todas as informações de entradas e saídas, de limites do sistema, informações regionais e temporais e o desenho da modelagem do sistema.

O processo estudado será o de construção do painel de concreto armado e blocos cerâmicos conforme descrito no capítulo 03, baseado em registros feitos no canteiro de obras durante um dia de trabalho. Será uma ACV com a finalidade de registro de informações, não comparativa, equivalente a opção "d" na relação do guia do ILCD.

O estudo será documentado neste capítulo. Pretende-se obter resultados para um estudo de ACV não comparativo, o objetivo é relatar os dados encontrados para o processo de construção do painel de blocos cerâmicos e concreto armado e concluir sobre o processo de aplicação da ferramenta.

A tabela 9 representa o resumo dos passos propostos pela metodologia do ILCD para a fase de escopo. Conforme ocorre na fase de objetivo, a tabela da fase de escopo foi derivada do questionário anexo (Anexo I) e guia a construção desta fase do estudo.

A função do painel de concreto armado e blocos cerâmicos é de vedação vertical de edificações.

Tabela 9: Tabela dos passos pedidos pelo ILCD - Fase de Escopo. Fonte: EUROPEAN COMMISSION, 2010.

\begin{tabular}{|l|l|l|}
\hline $\begin{array}{l}\text { Perguntas segundo a metodologia do } \\
\text { ILCD }\end{array}$ & $\begin{array}{l}\text { Respostas referentes ao painel } \\
\text { avaliado }\end{array}$ &
\end{tabular}


FASE DE ESCOPO

Qual será o método e quais serão os dados assumidos?

São métodos e dados consistentes
(precisos e completos)?
O processo será documentado?
Qual tipo de resultado se pretende
obter?
Qual o sistema ou processo que é
estudado?
Qual é a sua função?
Qual é a unidade funcional ou fluxo
de referência?
Quais são os métodos de medição?
São normatizados?
Quais são os passos da modelagem
do ICV?
do ICV?

É uma ACV atributiva ou consequencial? São utilizados métodos de alocação ou expansão do sistema/substituição?

Cobre quais impactos?

Todos os estágios relevantes do ciclo de vida que são operados na tecnosfera foram incluídos dentro dos limites do sistema?

Existe um diagrama dos limites do sistema?

Existe uma lista de exclusões?
Serão colhidos dados primários no canteiro de obras, o cálculo será feito no software Gabi e os dados secubdários serão do banco de dados do programa.

Sim.

Sim.

Estudo de ACV não comparativa.

A tecnologia de montagem do painel descrito no capítulo 02 .

Vedação vertical de edificações.

$1,312 m^{2}$ de painel no período de sua construção.

Verificação no local da obra, análise do projeto. As medições não são normatizadas.

Descrição e esquematização do processo de produção do painel que resultará no desenho do ciclo de vida e identificação dos processos participantes do sistema.

Atributiva.

Não.

Os essenciais para a elaboração de um EPD: GWP, AP, EP, ODP, OPCP, ADP elementos e ADP fóssil

Não. As etapas consideradas vão da extração de matéria prima até a saída da fábrica.

Sim.

Sim. 
Qual o valor de corte (\%) a ser aplicado para os produtos, perdas ou fluxos elementares que cruzam o sistema e não são quantificados?

São cobertas quais categorias padrões de impacto de AICV?
Não existem produtos, perdas ou fluxos elementares que cruzam os limites do sistema sem serem quantificados.

São cobertas quais categorias finais?

Danos à saúde humana, danos ao ecossistema, esgotamento de recursos naturais.

Quais são e como foram coletados os dados tecnológicos?

O desenho do sistema produtivo, descrição da produção, especificação dos materiais utilizados, projeto do painel, dados coletados no local, processos do banco de dados do software.

Os dados tem boa representatividade geográfica?

Os dados primários sim. Os dados secundários não.

Os dados tem boa representatividade temporal?

Sim. Os dados coletados no local e o banco de dados utilizados são do ano de 2013.

Quais o tipo, qualidade e fonte dos dados, a precisão desejada e a incerteza permitida?

Fontes primárias para o processo do painel e secundárias para os demais processos.

Foi identificada a necessidade de uma revisão crítica? 0 tipo de revisão e quem serão os revisores foram definidos?

Por não ser um estudo comparativo não há necessidade de revisão.

Qual tipo de divulgação de dados foi Pública. planejada?

A documentação dos métodos, incertezas e fontes de dados são apropriadas e transparentes?
Sim.

\subsection{Definição da unidade funcional.}

A unidade funcional foi definida baseada no caderno de projetos do Casa Express e em medições e observações feitas na obra. Ela representa uma fração do 
painel pré-moldado de blocos cerâmicos e concreto armado que poderá ser multiplicada para obtenção de resultados referentes aos painéis.

A figura 17 apresenta exemplos de painéis do modelo de casa a ser construída no Riacho Fundo II. Observa-se na parede P01 que na extensão de 2,52m de parede são usados sete blocos cerâmicos de $30 \times 30 \mathrm{~cm}$, bordas de concreto de $12 \mathrm{~cm}$ onde vão treliças de ferro e $3 \mathrm{~cm}$ de concreto entre os blocos. A altura das janelas é de $2,16 \mathrm{~m}$, alinhadas com a altura das portas conforme P03. Até a altura de $2,16 \mathrm{~m}$ são utilizados seis blocos de $30 \times 30 \mathrm{~cm}$ ou cinco blocos de $30 \times 30 \mathrm{~cm}$ e dois de $15 \times 30 \mathrm{~cm}$. As lacunas são preenchidas com vergalhões de ferro e concreto. O projeto prevê o espaço para ferragens entre dez e treze centímetros, depende do conteúdo da parede.

Acima da altura de $2,16 \mathrm{~m}$ os painéis apresentam uma composição diferenciada, composta por alguns blocos menores, ou sem nenhum bloco, apenas concreto e ferragem, conforme indicado na P04 (Figura 17).

Baseada nas observações dos projetos dos painéis a unidade funcional definida considera uma fração do painel composta pelos componentes básicos: blocos, concreto e ferragem. Não considera passagem de tubulação e nenhum componente da estrutura elétrica ou hidráulica da casa. Também não considera esquadrias. 


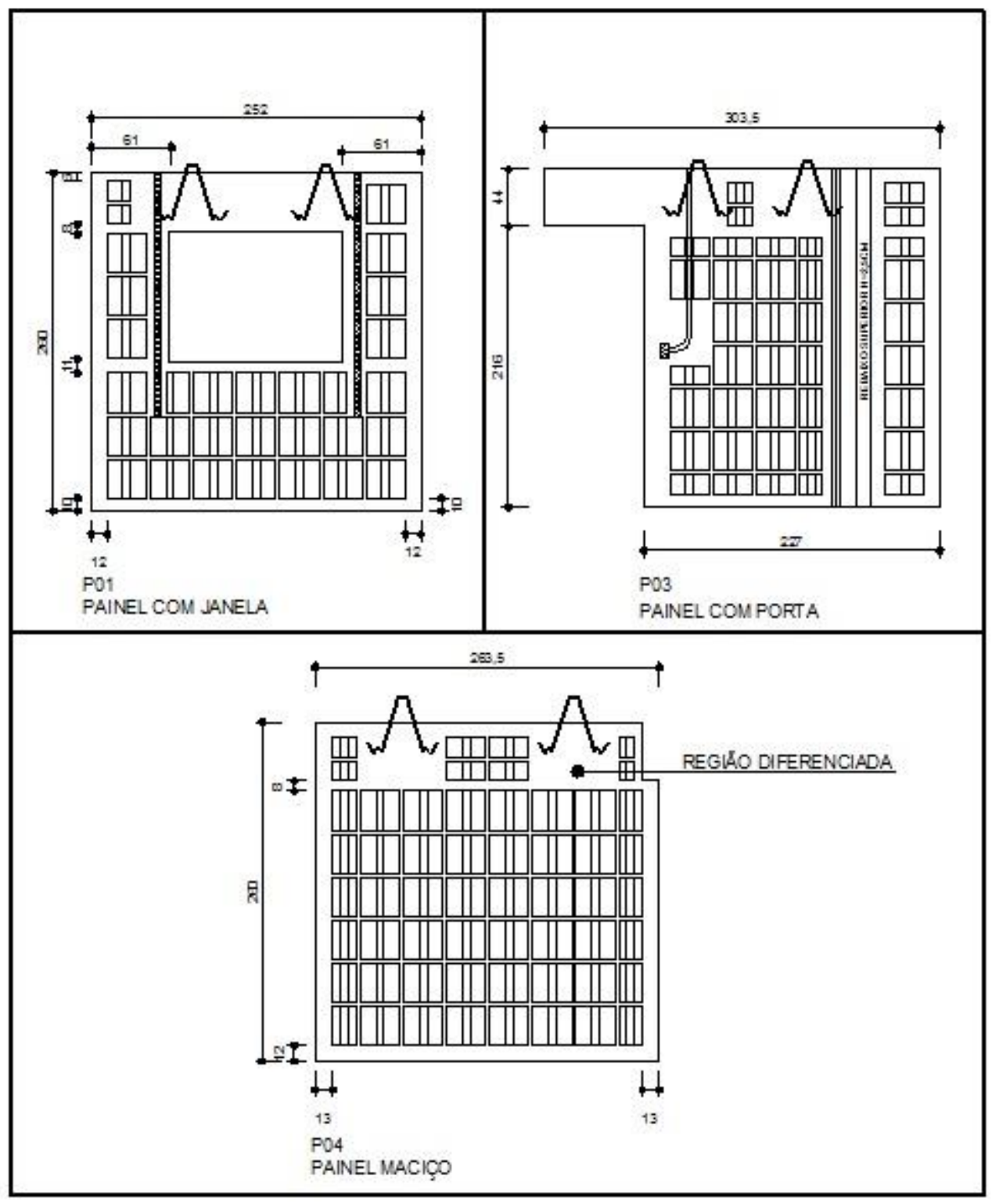

Figura 16: Estudo dos painéis para definição da unidade funcional.

Assim, uma parede maciça com blocos inteiros, com dimensões de $2,52 \mathrm{~m} \times$ $2,60 \mathrm{~m} \times 0,11 \mathrm{~m}$, tem volume de $0,72 \mathrm{~m}^{3}$, contém 45 blocos, $0,47 \mathrm{~m}^{3}$ de concreto, 20 barras de soldagem de aço CA 50 , diâmetro $8 \mathrm{~mm}$, com $18 \mathrm{~cm}$ de comprimento, 02 ganchos de içamento de aço CA50, diâmetro $8 \mathrm{~mm}$, com 1,5m de comprimento, 16 barras de aço CA60, diâmetro 4,2mm, com 2,60m e 15 barras de aço CA60 com 2,52m de comprimento (figura 18)

Para definição da unidade funcional foi considerada uma fração que representa $1 / 5$ do painel apresentado na figura 18 , com $1,085 \mathrm{~m} \times 1,21 \mathrm{~m} \times 0,11 \mathrm{~m}$, com 
volume de $0,144 \mathrm{~m}^{3}$, dimensões que consideram nove blocos inteiros de $30 \times 30 \mathrm{~cm}$ posicionados conforme o projeto, volume de concreto de 0,094m³, 04 barras de soldagem, $60 \mathrm{~cm}$ de gancho de içamento, 08 barras CA60 de 1,085m e 06 barras CA60 de $1,21 \mathrm{~m}$. A área da fração definida é de $1,312 \mathrm{~m}^{2}$. Esta fração contém 1/5 de todos os elementos do painel de forma que possa ser facilmente multiplicada e compor paredes inteiras com a quantidade de elementos bem próxima do painel real (figura 18). A espessura da parede especificada em projeto é de $11 \mathrm{~cm}$.

Como definições citam-se:

Função: vedação vertical de edificações;

Unidade funcional: $1,312 \mathrm{~m}^{2}$ de painel que cumpre a função de vedação vertical pelo tempo mínimo estabelecido pela ABNT: NBR 15575/13;

Faz parte da definição da unidade funcional a dimensão do tempo previsto em que ela deve cumprir sua função com qualidade. Como o limite do sistema estudado termina quando o painel sai do canteiro para a construção da edificação este estudo não engloba a avaliação do tempo de vida útil. Será considerado que ele cumpre sua função pelo tempo mínimo sugerido pela ABNT: NBR 15575/13.

A metodologia do ILCD pede a especificação da qualidade da unidade funcional de acordo com a maneira ("in what way and how well") que ela cumpre sua função. Considerando que a unidade definida é uma fração com todos os componentes de um painel maciço (sem esquadrias ou tubulações) identifica-se que a unidade funcional cumpre a função de vedação vertical com qualidade.

O método de medição conta com as dimensões e especificações do projeto, conferidas no local, e com informações colhidas com o responsável pela obra. 

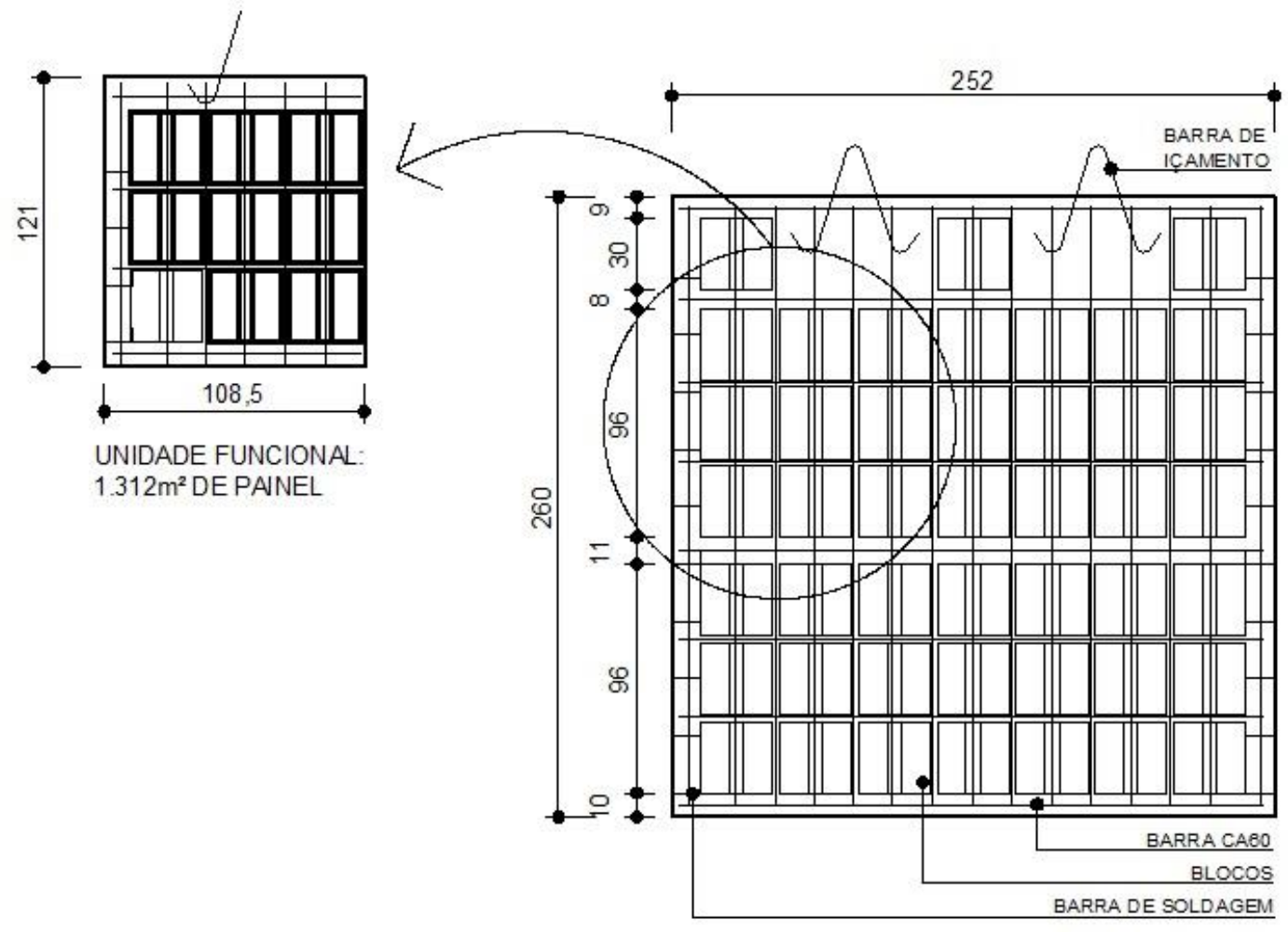

UNIDADE FUNCIONAL: $1.312 \mathrm{~m}^{2}$ DE PAINEL

PAINEL MACIÇO

Figura 17: Representação da unidade funcional - uma fração do painel com a mesma proporção de elementos do todo.

3.4 Modelagem do Inventário de Ciclo de Vida (ICV).

Para a definição da modelagem do Inventário de Ciclo de Vida (ICV) o sistema analisado foi identificado como Situação C, prevista no manual ILCD, porque tem a intenção de gerar informação, sem consequências para o mercado em que o produto está inserido. Para esta situação o modelo recomendado é o atributivo, que descreve os processos existentes dentro dos limites do sistema.

Os passos utilizados para a modelagem do ICV incluem a descrição e esquematização do processo de produção do painel realizada no capítulo 3 que permite a modelagem do ciclo de vida e a identificação de todos os materiais e processos utilizados. Desta forma os dados quantitativos para os materiais e processos devem ser levantados. 
Não será necessário a utilização de métodos de alocação ou substituição por se tratar de um estudo simples, onde não há multifuncionalidade e tem apenas o painel como produto do sistema.

Segundo o manual do ILCD, um estudo de ACV deve cobrir impactos na saúde humana, no meio-ambiente natural e nos recursos naturais, que são causados por intervenções entre a Tecnosfera e a Ecosfera durante a operação normal e anormal do sistema, excluindo acidentes (WOLF et al, 2012).

O ILCD sugere a consideração das seguintes categorias de impactos:

- Potencial de mudança climática;

- Potencial de depleção da camada de ozônio;

- Potencial de toxicidade humana;

- Potencial de liberação de inorgânicos respiratórios;

- Potencial de liberação de radiação ionizante;

- Potencial de formação fotoquímica de ozônio;

- Potencial de acidificação;

- Potencial de eutrofização;

- Potencial de ecotoxicidade;

- Uso da terra;

- Potencial de esgotamento de recursos naturais.

Para a elaboração deste exercício será suficiente considerar as categorias identificadas como essenciais pela norma europeia EN 15804:2012+A1:2013 para a elaboração de uma declaração ambiental de produto, ou Environmental Product Declaration (EPD), definidas pela Universidade de Leiden (CML):

- Mudança climática ou potencial de aquecimento global;

- Potencial de acidificação das águas do solo e do ar;

- Potencial de eutrofização;

- Potencial de depleção da camada de ozônio;

- Potencial de formação fotoquímica de ozônio;

- Depleção de recursos abióticos - elementos;

- Depleção de recursos abióticos - fóssil; 
Os dados do processo tecnológico foram colhidos no local conforme descrito no capítulo anterior e os dados dos materiais foram retirados do banco de dados do software Gabi. Os dados primários tem boa representatividade geográfica e temporal por se referirem à obra em andamento. Os dados secundários nem tanto, a disponibilidade de dados brasileiros no banco de dados do Gabi Educational do ano de 2013 é pequena, para suprir esta falta foram usados dados europeus.

Para este tipo de estudo, por não ser comparativo, o ILCD determina que a revisão crítica não é exigida. Como uma das intenções do estudo é a contribuição com a geração de dados para uso da ferramenta de ACV, a divulgação deve ser pública.

\subsection{Limites do Sistema}

O ciclo de vida completo de um produto, conforme já comentado, inclui desde a extração de matéria prima, passando pela produção, fase de uso e descarte. $\mathrm{Na}$ fase de definição de escopo da ACV é preciso especificar quais processos serão incluídos no estudo e quais serão excluídos.

A metodologia do ILCD recomenda que isso seja feito com a ajuda de um diagrama das fronteiras do sistema. Este diagrama mostra os limites entre o processo modelado e o resto da tecnosfera (WOLF et al, 2012).

Segundo material de treinamento para o software Gabi 6 Educational da PE International, disponível em janeiro de 2015 em sua página na internet existem quatro principais opções para definir as fronteiras do sistema (figura 19).

São elas:

- Da extração de matéria prima até o descarte do produto (cradle to grave);

- Da extração de matéria prima à saída dos portões da fábrica (cradle to gate);

- Da saída dos portões da fábrica até o descarte do produto (gate to grave);

- Dentro dos portões da fábrica (gate to gate); 
Neste estudo a fronteira considerada engloba da extração de matéria prima até a saída do produto pelos portões da fábrica. A exclusão das demais fases do ciclo de vida se justifica por considerar que o painel depois de instalado passa a fazer parte de um produto mais complexo que é a edificação, que exige um estudo extenso, com diferentes cenários a serem considerados e um tempo longo de duração. Isso extrapola os objetivos do estudo.

PRINCIPAIS OPÇõES PARA DEFINIÇÃO dOS LIMITES DO SISTEMA

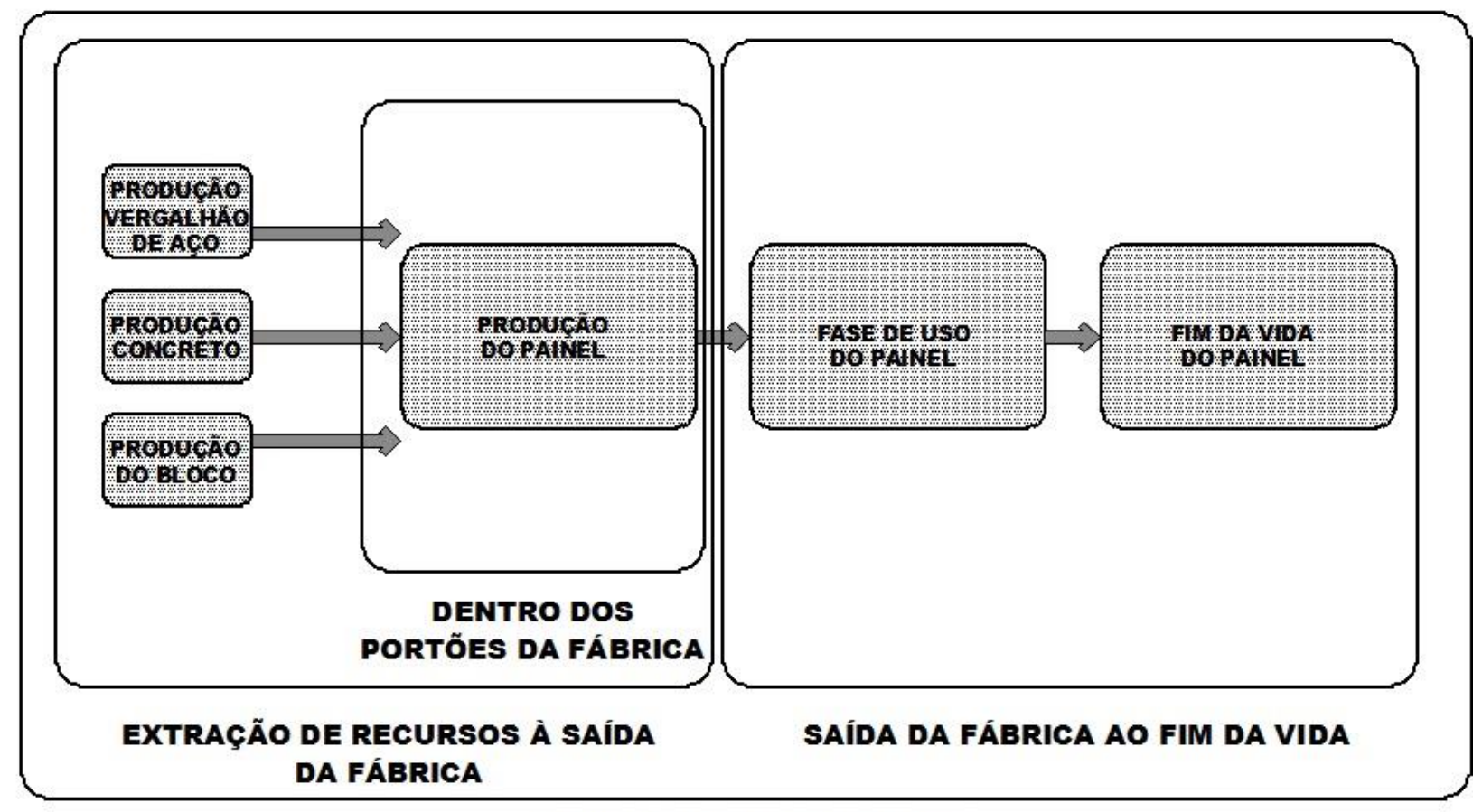

CICLO DE VIDA COMPLETO

DA EXTRAÇÃo DE RECURSOS AO FIM DA VIDA

Figura 18: Opções para definição dos limites do sistema. Fonte: PE International. 
A figura 20 ilustra o diagrama dos limites do sistema para a ACV do painel de

DEFINIÇÃo dOS LIMITES DO SISTEMA

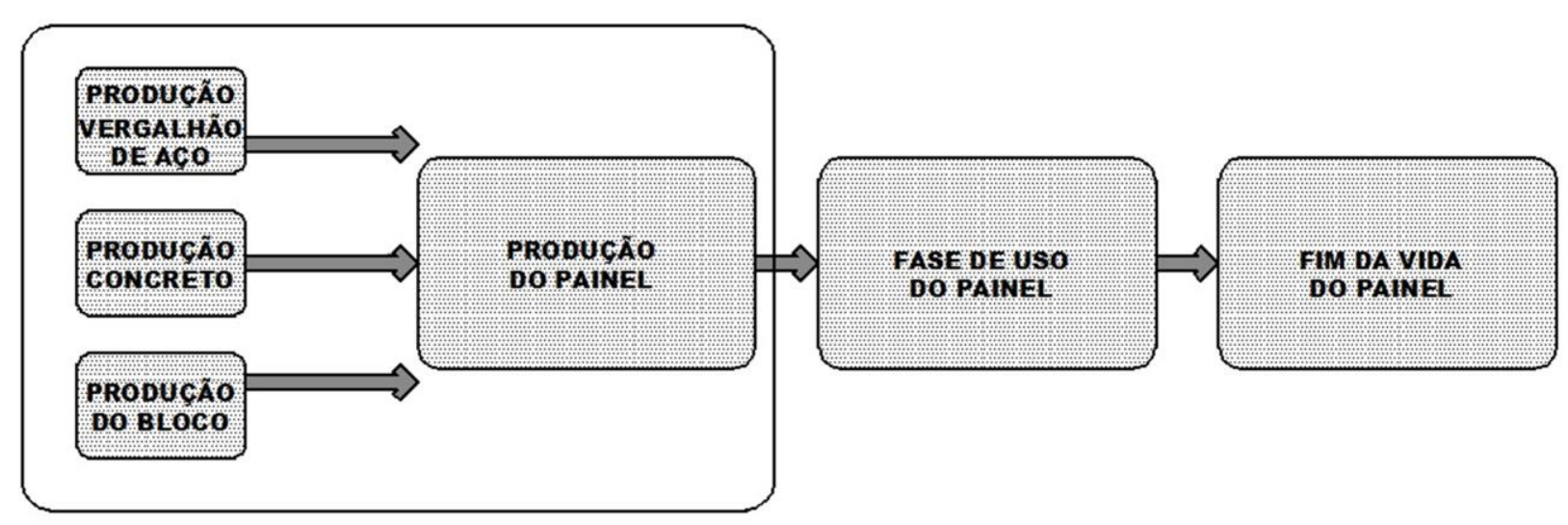

EXTRAÇÃO DE RECURSOS À SAÍDA

DA FÁBRICA

Figura 19: Limites do sistema da ACV do painel de blocos cerâmicos e concreto armado.

blocos cerâmicos e concreto armado.

A lista de exclusões do sistema inclui:

- Toda fase de uso do painel;

- O processo de descarte e final de vida do painel.

3.6 Fase de Inventário

$\mathrm{Na}$ fase de inventário são realizadas a coleta de dados e a modelagem do sistema. Os resultados desta fase normalmente são demonstrados em uma planilha que contém todas as entradas e saídas de materiais e energias do sistema. Ela fornece os dados para a fase seguinte que é a avaliação dos impactos (PE International, 2015).

Os impactos calculados nesta fase se referem exclusivamente às intervenções entre o sistema analisado e a ecosfera, causados durante a operação normal dos processos incluídos, excluindo casos de acidentes, que devem ser modelados em situações específicas (WOLF et al, 2012). 
Os primeiros passos recomendados para a coleta de dados são: identificar os processos existentes dentro das fronteiras do sistema e os fluxos elementares, fluxos de produtos e fluxo de resíduos.

Os fluxos de entrada e saída que se relacionam com a ecosfera como recursos, emissões, uso da terra, etc., são os fluxos elementares. Os fluxos de produtos são os que acontecem entre os processos e o fluxo de resíduos são os que precisam ser ligados aos processos de gerenciamento de resíduos para que a modelagem e a avaliação dos impactos seja completa (WOLF et al, 2012).

Os passos propostos pelo manual do ILCD para esta fase, relativos ao modelo atributivo que é o caso deste estudo, estão resumidos na tabela 10.

Tabela 10: Tabela dos passos identificados pelo ILCD - Fase de Inventário. Fonte: EUROPEAN COMMISSION 2010.

\begin{tabular}{|l|l|l|l} 
Perguntas segundo metodologia do & $\begin{array}{l}\text { Respostas referentes ao painel } \\
\text { avaliado }\end{array}$ \\
ILCD &
\end{tabular}

\section{FASE DE INVENTÁRIO}

Existe uma descrição do sistema Sim.

principal e da unidade funcional?

Quais são os fluxos de entrada e de Estão demonstrados na figura 24. saída do processo?

O sistema analisado é atributivo ou Atributivo. consequencial?

Se atributivo:

\begin{tabular}{|c|c|}
\hline Os processos foram identificados? & Sim. Figura 24. \\
\hline Qual é o processo central do sistema? & $\begin{array}{l}\text { Produção do painel de blocos cerâmicos } \\
\text { e concreto armado }\end{array}$ \\
\hline $\begin{array}{l}\text { Quais outros processos fazem parte } \\
\text { do sistema primário? (Nível 1) }\end{array}$ & $\begin{array}{l}\text { Produção dos blocos cerâmicos, } \\
\text { vergalhão de aço e concreto. Figura } 22 .\end{array}$ \\
\hline $\begin{array}{l}\text { Quais processos fazem parte do } \\
\text { sistema secundário? (Nível 2) }\end{array}$ & Não há. \\
\hline Existem processos de nível 3? & Não. \\
\hline $\begin{array}{l}\text { Existe documentação de algum } \\
\text { processo excluído? }\end{array}$ & $\begin{array}{l}\text { O processo de extração de argila dentro } \\
\text { do processo de produção do bloco } \\
\text { cerâmico foi substituído. }\end{array}$ \\
\hline $\begin{array}{l}\text { Existe documentação de relações com } \\
\text { outros sistemas? }\end{array}$ & Não. \\
\hline $\begin{array}{l}\text { Existe o diagrama de fluxos do } \\
\text { sistema principal e listagem dos }\end{array}$ & $\begin{array}{l}\text { Existe diagrama de fluxos do sistema } \\
\text { principal. Não são considerados } \\
\text { processos secundários. }\end{array}$ \\
\hline
\end{tabular}


produtos e perdas que ligam o sistema principal ao sistema secundário?

Foram identificados para quais Sim. Foi montado o processo do bloco processos precisarão ser cerâmico.

desenvolvidos novos processos para completar o sistema?

Dados primários e dados genéricos Sim. Tabela 13.

estão identificados?

As fontes dos dados estão Sim. Tabela 13. identificadas?

A representatividade do processo Sim. Está descrito no capítulo 02. principal, em relação à tecnologia, técnica, geografia, escopo de mercado e tempo, está identificada?

A unidade funcional ou o fluxo de referência estão identificados?

As quantidades referentes aos fluxos de entrada e saída dos processos foram especificadas?

Houve checagem dos dados coletados para alinhá-los com o objetivo do estudo?

Algum dado não pode ser encontrado?

Sim. Item 2 capítulo 03.

Sim. Tabela 11.

Sim, foram coletados de acordo com o objetivo.

Sim. Alguns dados referêntes ao processo do bloco cerâmico não foram encontrados, como o processo de produção da argila e a distância dos fornecedores de matéria prima.

Como a falta de dados foi Foram usados dados genéricos e solucionada? processos similares.

Os dados não encontrados foram Sim. O processo está descrito neste documentados?

Todos os processos foram Sim. $\mathrm{Kg}$.

convertidos na mesma unidade de medida?

Todos os processos e fluxos Sim. Figura 23. relevantes foram modelados?

Os dados faltantes foram completados Sim.

com dados consitentes?

Os dados usados para substituir os Sim, segundo a classificação do Gabi. faltantes são dados de qualidade?

Os passos referentes ao modelo consequencial e a alguns modelos específicos como sistemas agroflorestais e sistemas de tratamento de resíduos não foram considerados por não se aplicarem aos nossos objetivos. 
Os passos da tabela foram seguidos para montar o inventário de forma a cumprir todos os requisitos. A descrição do sistema está detalhada no capítulo $02 \mathrm{e}$ segue o esquema da figura 15 e a unidade funcional está descrita no item 3.3 deste texto - fase de escopo.

Conforme classificado na fase de escopo, o sistema é considerado atributivo, pois é classificado na situação $C$, com a finalidade de gerar dados sem grandes consequências no mercado. Isso orienta o processo para uma modelagem onde os processos são descritos e ligados entre si, sem considerar cenários diferenciados.

Para a identificação dos processos o ILCD recomenta que eles sejam divididos em níveis, de forma que o nível 0 englobe o processo principal que fornece a unidade funcional ou fluxo de referência; o nível 1 engloba os processos dos materiais que compõe fisicamente a unidade funcional; o nível 2 engloba os processos de produtos ou serviços que se relacionam com a unidade funcional de forma a completá-la ou aperfeiçoá-la; e o nível 3 engloba processos que não tem relação direta com a construção da unidade funcional mas se relaciona com ela em segundo plano.

A figura 21 ilustra a divisão dos processos em níveis com o objetivo de facilitar a identificação destes processos.

Os limites da ACV deste estudo engloba processos do nível 0 e nível 1 , sendo que no nível 0 está o processo de construção do painel e no nível 1 os processos de produção dos seus componentes, conforme figura 22.

Neste estudo os processos referentes ao concreto, bloco cerâmico e vergalhão de aço foram encontrados prontos no banco de dados dos softwares Gabi 6 Educational e SimaPro 8.0. 


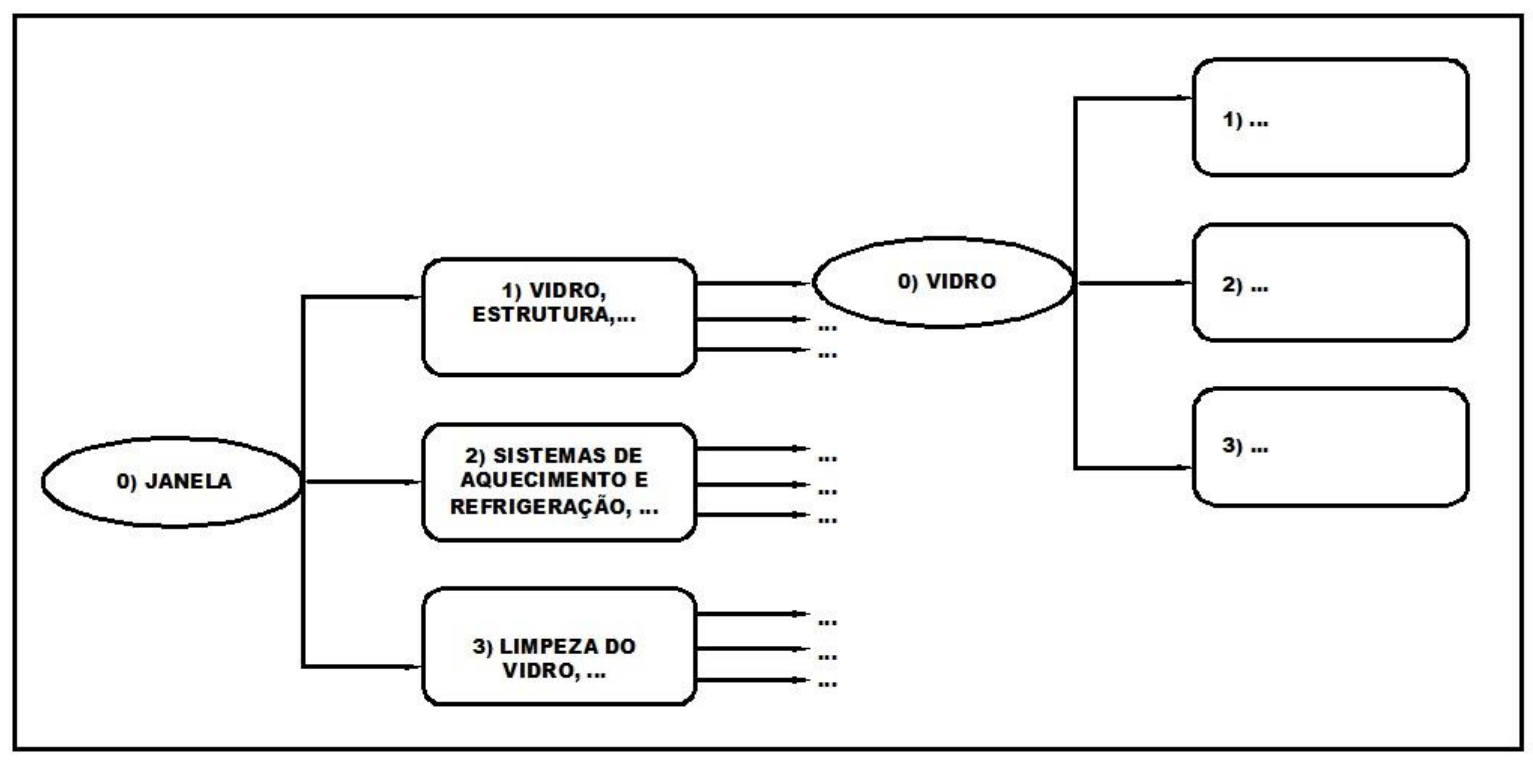

Figura 20: Divisão dos processos em níveis. Fonte: EUROPEAN COMMISSION, 2010.

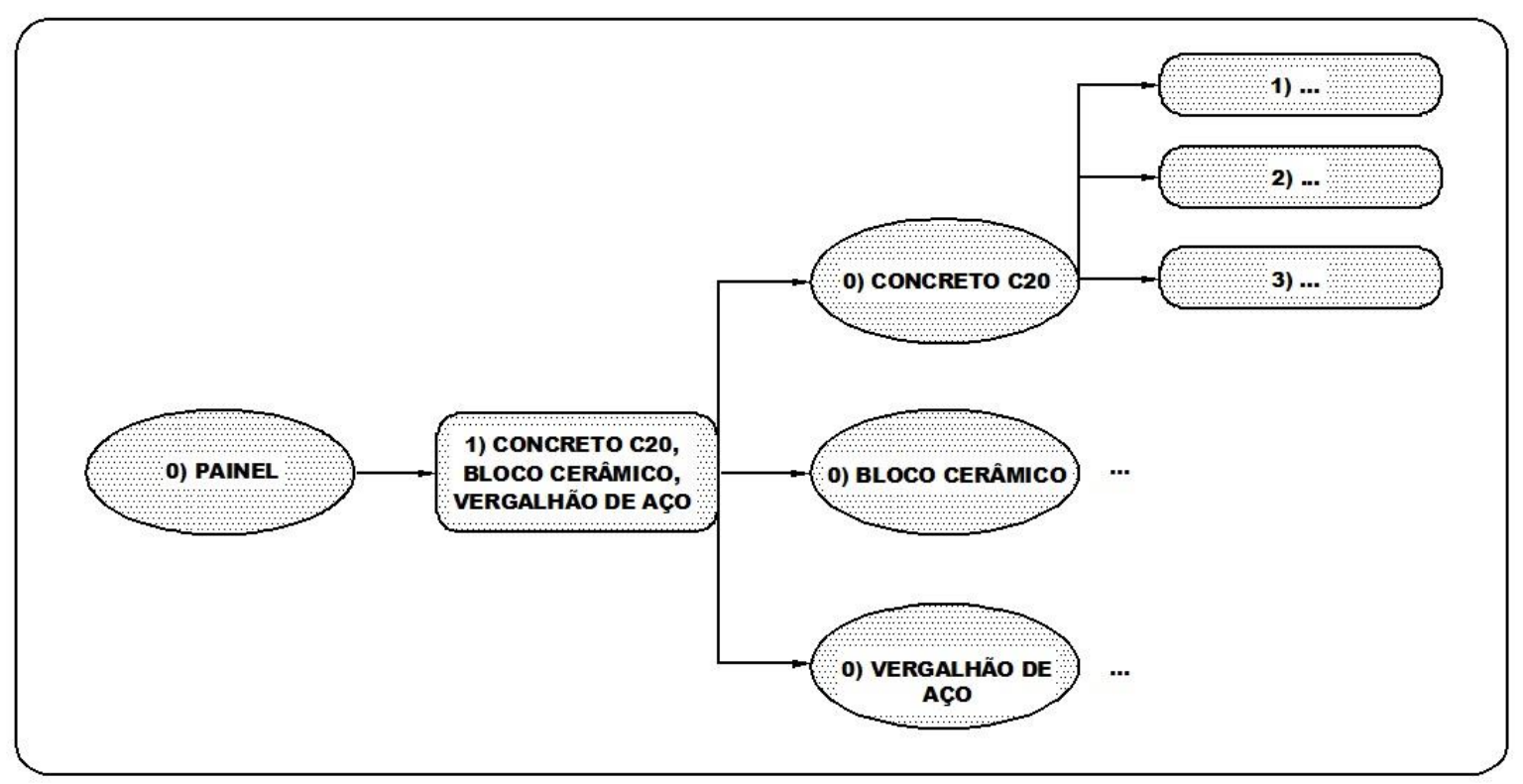

Figura 21: Divisão dos processos do painel de blocos cerâmicos e concreto armado.

Para o cálculo dos impactos é preciso modelar os processos e fluxos no software Gabi, da PE Inernational, onde a unidade padrão é massa, medida em Kg. 
Para isso é preciso que todos os materiais contidos na fração definida sejam representados em massa.

A tabela 11 informa o levantamento de materiais referende à unidade funcional, conforme descrita no item 3.3 deste texto.

Tabela 11: Materiais referentes à unidade funcional: quantidades, unidades e massas.

\begin{tabular}{|c|c|c|c|}
\hline \multicolumn{4}{|c|}{ LEVANTAMENTO DOS MATERIAIS CONTIDOS EM UMA UNIDADE FUNCIONAL } \\
\hline MATERIAIS & QTDD. & UNIDADE & MASSA (Kg) \\
\hline Blocos cerâmicos & 9 & unidades & 28,8 \\
\hline Concreto C20 & 0,094 & $\mathrm{~m}^{3}$ & 230,68 \\
\hline Barras de soldagem CA50 $\varnothing 8 \mathrm{~mm} 18 \mathrm{~cm}$ & 4 & unidades & \\
\hline Ganchos de içamento CA50 $\varnothing 8 \mathrm{~mm} 60 \mathrm{~cm}$ & 1 & unidade & 0,521 \\
\hline Malha CA60 Ø4,2mm 108,5cm & 8 & unidades & \\
\hline Malha CA60 $\varnothing 4,2 \mathrm{~mm} 121 \mathrm{~cm}$ & 6 & unidades & 1,737 \\
\hline & & MASSA TOTAL & 261,738 \\
\hline
\end{tabular}

Os dados referentes à quantidade, peso e especificação dos materiais utilizados para a confecção do painel são dados primários, coletados no canteiro de obras, no projeto da casa, em informações dos fabricantes ou normas técnicas.

Cada bloco cerâmico utilizado no painel mede $30 \times 30 \times 06 \mathrm{~cm}$ e pesa $3,2 \mathrm{Kg}$ segundo projeto e pesagem realizada na obra com uma balança suspensa portátil com gancho para uso doméstico.

O peso específico de $1 \mathrm{~m}^{3}$ de concreto simples é de $24 \mathrm{KN}$, ou $2447,32 \mathrm{Kg}$, segundo ABNT NBR 6120/1980.

O catálogo da empresa produtora de aço Gerdau informa que o vergalhão CA50 com $8 \mathrm{~mm}$ de diâmetro apresenta $0,395 \mathrm{Kg} / \mathrm{m}$ e o CA60 com 4,2mm de diâmetro apresenta 0,109 Kg/m.

Com o levantamento destas informações foi montado um plano de trabalho no software Gabi 6 Educational representando os processos que fazem parte do sistema. O processo central é a montagem do painel, que tem como fluxos de entrada o concreto, o vergalhão de aço e o bloco cerâmico e seus processos de transporte; e como fluxo de saída o painel pronto. O modelo principal ficou conforme a figura 23. A figura 24 representa de forma simplificada e traduzida o mesmo esquema montado no software. Ela demonstra os processos do sistema central e os fluxos de entrada e saída. 
O software contém em seu banco de dados as informações do processo de produção do concreto CA20/CA25, do vergalhão de aço e do transporte dos materiais por caminhão da sua origem até o canteiro de obras.

O processo do bloco cerâmico não consta no banco de dados do Gabi 6 Educational e foi modelado manualmente para que todas as entradas e saídas de sua produção sejam contabilizadas. Os dados referentes às estas entradas e saídas foram retirados do software SimaPro 8.0 Demo e estão apresentados na figura 25.

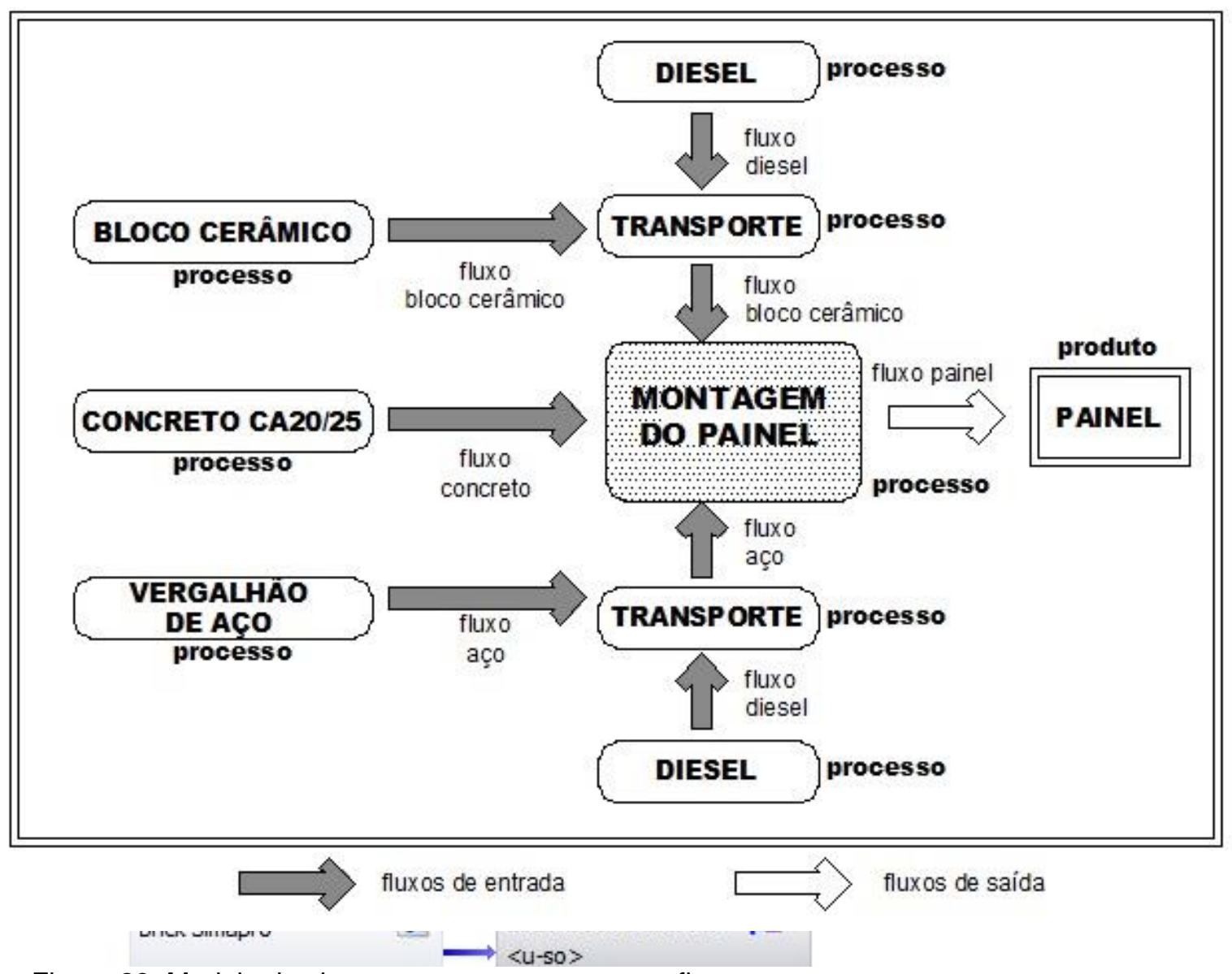

Figura 23: Modelo do sistema, com os processos e fluxos.

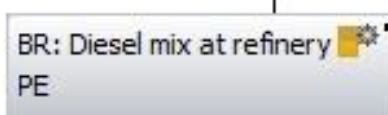

Figura 22: Modelo do sistema montado no software Gabi 6.0.

Para que fosse possível incluir manualmente o processo do bloco cerâmico no plano de trabalho do Gabi todos os processos referentes aos fluxos de entrada da produção do bloco foram retirados do banco de dados deste software. A solução 
adotada para os processos não existentes no banco de dados foi a escolha de um outro processo relativamente próximo para aproximar o resultado da realidade. Esta solução foi necessária somente no caso do processo da extração de argila, que foi substituído pelo processo de extração de areia.

A distância considerada para o transporte dos blocos cerâmicos foi a de Silvânia - GO até o Riacho Fundo - DF informada pelo Google Mapas, de 179 Km.

Para o transporte do vergalhão de aço foi considerada a unidade produtora de aço e laminados da Gerdau mais próxima do DF, que fica em Divinópolis - MG, segundo informações do site da Gerdau. Esta distância, informada pelo Google Mapas, é de $746 \mathrm{Km}$.

O concreto é produzido no canteiro de obras. Para os processos do sistema de produção do bloco cerâmico foi considerada uma distância média de $100 \mathrm{Km}$ entre fornecedores de matéria prima e fábrica, já que não foram levantadas informações sobre a produção do bloco.

A tabela 12 mostra as distâncias consideradas para os processos do sistema central.

Tabela 12: Distâncias consideradas para o transporte de materiais.

\begin{tabular}{|l|l|l|r|}
\hline \multicolumn{4}{|c|}{ DISTÂNCIAS CONSIDERADAS PARA O TRANSPORTE DE MATERIAIS } \\
\hline \multicolumn{1}{|c|}{ MATERIAL } & LOCAL DE PRODUÇÃO & \multicolumn{1}{c|}{ LOCAL DE DESTINO } & DISTÂNCIA EM Km \\
\hline Blocos cerâmicos & Silvânia - GO & Riacho Fundo - DF & 179 \\
\hline vergalhões de aço & Divinópolis - MG & Riacho Fundo - DF & 746 \\
\hline concreto & Riacho Fundo - DF & Riacho Fundo - DF & 0 \\
\hline
\end{tabular}

Para a modelagem do processo do bloco cerâmico foi considerada inicialmente uma distância padrão de $200 \mathrm{~km}$ entre todos os fornecedores e a fábrica do bloco. Depois o cálculo foi refeito com a distância padrão de $500 \mathrm{Km}$ e $1000 \mathrm{Km}$, para fazer uma análise de sensibilidade em relação ao impacto do transporte nesta produção. A modelagem considerando os processos da produção do painel e da produção do bloco cerâmico ficou conforme figura 25.

Para o cálculo dos resultados o processo de produção do bloco cerâmico foi separado em outro plano de trabalho do software Gabi e este plano foi inserido na modelagem do sistema principal. Desta forma os resultados para o sistema estudado 
consideram o componente bloco cerâmico como um processo fechado, assim como o processo do concreto e do vergalhão de aço presentes no banco de dados do programa.

Se todos os processos que compõe a produção do bloco ficarem inseridos no mesmo plano de trabalho o cálculo apresentará resultados desmembrados para cada processo e tornará o resultado confuso. Nesta opção de modelagem adotada os resultados de todos estes processos serão englobados no processo do bloco cerâmico.

A tabela 13 identifica a origem dos dados utilizados. 


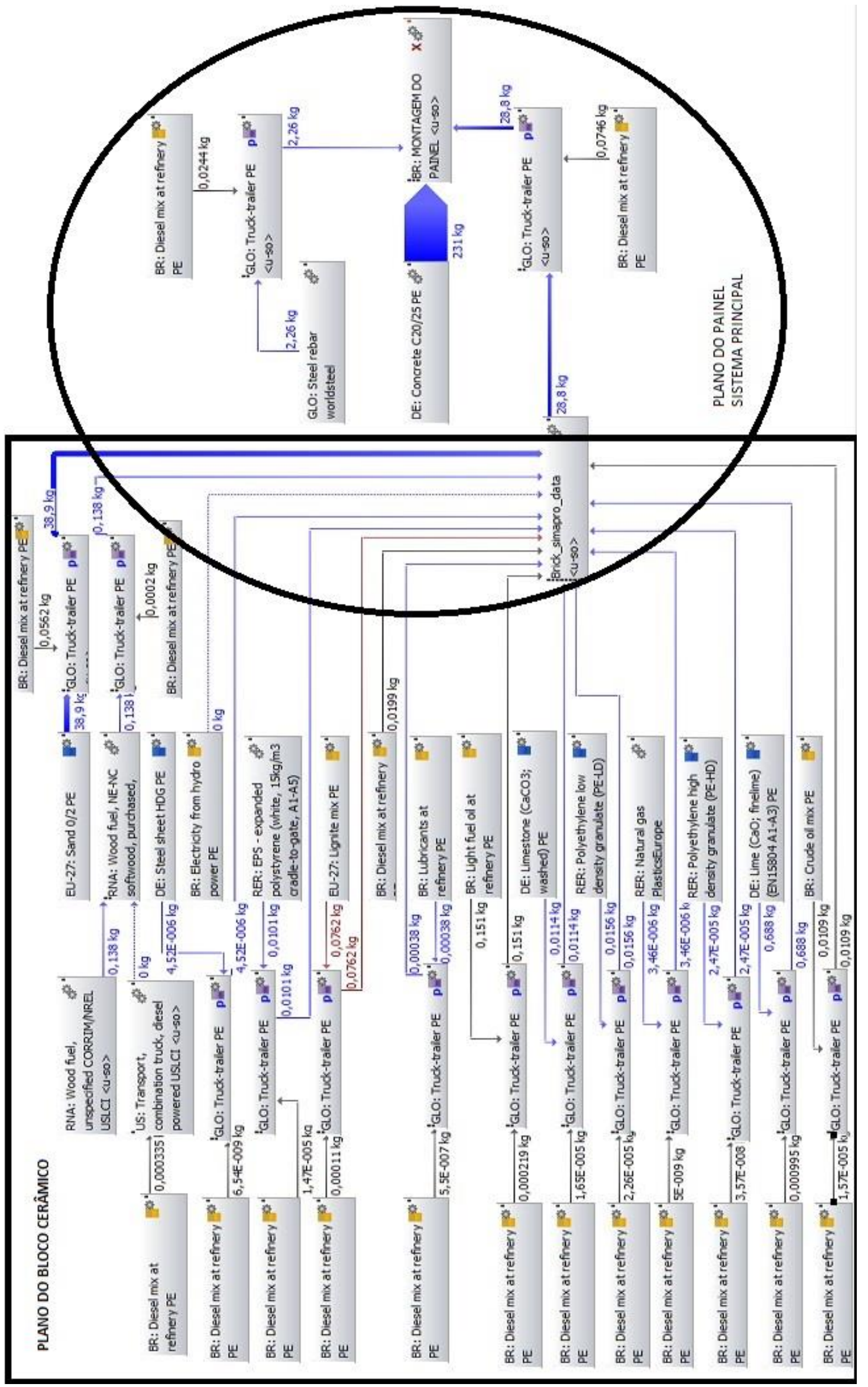

Figura 24: Divisão dos processos adotada no estudo do painel de blocos cerâmicos e concreto 
Tabela 13: Origem dos dados.

\begin{tabular}{|c|c|c|c|}
\hline \multicolumn{4}{|c|}{ INFORMAÇÕES SOBRE OS DADOS } \\
\hline DADOS DO PROCESSO DA MONTAGEM DO PAINEL & FONTE & TIPO & ORIGEM \\
\hline Materiais utilizados & Visita ao local/ projeto & primário & Local \\
\hline Quantidade de materiais utilizados & Visita ao local/ projeto & primário & Local \\
\hline Processo produtivo do painel & Visita ao local/ projeto & primário & Local \\
\hline Processo produtivo do concreto & Banco de dados Gabi & secundário & Alemanha \\
\hline Distância percorrida pelo transporte do concreto & Visita ao local/ projeto & primário & Local \\
\hline Processo produtivo vergalhão de aço & Banco de dados Gabi & secundário & Global \\
\hline Distância percorrida pelo transporte do aço & Localização da fábrica & primário & Local \\
\hline Dados sobre fluxos do bloco cerâmico & Banco de dados SimaPro & secundário & Global \\
\hline Distância percorrida pelo transporte do bloco & Localização da fábrica & primário & Local \\
\hline Dados sobre os caminhões de transporte & Banco de dados Gabi & secundário & Global \\
\hline Dados sobre o diesel do caminhão & Banco de dados Gabi & secundário & Brasil \\
\hline DADOS DO PROCESSO DO BLOCO CERÂMICO & FONTE & TIPO & ORIGEM \\
\hline Materiais utilizados & Banco de dados SimaPro & secundário & Global \\
\hline Quantidade de materiais utilizados & Banco de dados SimaPro & secundário & Global \\
\hline Processo produtivo do bloco & Banco de dados SimaPro & secundário & Global \\
\hline $\begin{array}{l}\text { Processo produtivo da areia - substituição do } \\
\text { processo da argila que não consta no banco de } \\
\text { dados }\end{array}$ & Banco de dados Gabi & secundário & Europa \\
\hline Processo produtivo do combustível de madeira & Banco de dados Gabi & secundário & \\
\hline processo produtivo da chapa de aço & Banco de dados Gabi & secundário & Alemanha \\
\hline $\begin{array}{l}\text { processo produtivo da eletricidade de } \\
\text { hidroelétrica }\end{array}$ & Banco de dados Gabi & secundário & Brasil \\
\hline processo produtivo do poliestireno espandido & Banco de dados Gabi & secundário & \\
\hline processo produtivo da lignite & Banco de dados Gabi & secundário & Europa \\
\hline processo produtivo do diesel & Banco de dados Gabi & secundário & Brasil \\
\hline processo produtivo do lubrificante & Banco de dados Gabi & secundário & Brasil \\
\hline processo produtivo do óleo leve & Banco de dados Gabi & secundário & Brasil \\
\hline processo produtivo do calcário & Banco de dados Gabi & secundário & Alemanha \\
\hline $\begin{array}{l}\text { processo produtivo do polietileno de baixa } \\
\text { densidade }\end{array}$ & Banco de dados Gabi & secundário & \\
\hline $\begin{array}{l}\text { processo produtivo do polietileno de alta } \\
\text { densidade }\end{array}$ & Banco de dados Gabi & secundário & \\
\hline processo produtivo do gás natural & Banco de dados Gabi & secundário & \\
\hline processo produtivo do cal & Banco de dados Gabi & secundário & Alemanha \\
\hline processo produtivo do óleo cru & Banco de dados Gabi & secundário & Brasil \\
\hline $\begin{array}{l}\text { Distância percorrida pelo transporte das matérias } \\
\text { primas }\end{array}$ & Padrão & genérico & \\
\hline Dados sobre os caminhões de transporte & Banco de dados Gabi & secundário & Global \\
\hline Dados sobre o diesel do caminhão & Banco de dados Gabi & secundário & Brasil \\
\hline
\end{tabular}




\subsection{Cálculo dos resultados da AICV.}

Nesta fase os fluxos elementares de entrada e saída levantados no inventário são convertidos em indicadores de impactos relacionados à saúde humana, meioambiente natural e esgotamento de recursos (WOLF et al, 2012).

O manual do ILCD observa que os resultados da AICV devem ser vistos como indicadores de potenciais impactos relevantes ao meio-ambiente, e não como previsões dos atuais efeitos ao meio ambiente (WOLF et al, 2012).

Os passos recomendados no manual para a fase de cálculo da AICV estão resumidos na tabela 14.

Tabela 14: Tabela dos passos pedidos pelo ILCD - Fase de cálculo do AICV. Fonte: EUROPEAN COMMISSION, 2010.

\begin{tabular}{|l|l|l|l|l}
$\begin{array}{l}\text { Perguntas segundo metodologia do } \\
\text { ILCD }\end{array}$ & $\begin{array}{l}\text { Respostas referentes ao painel } \\
\text { avaliado }\end{array}$
\end{tabular}

FASE DE CÁLCULO DO AICV

Todos os fluxos elementares estão Sim.

ligados à uma ou mais categorias de impacto?

O quantitativos dos fluxos Sim.

elementares estão expressados nas

unidades referentes a cada categoria?

Os resultados são expressados por Sim.

categorias de impactos?

Os resultados de longo prazo (mais de Não.

100 anos da data do estudo) foram

calculados separadamente?

O programa Gabi 6 Educational fornece como resultado os gráficos sobre quanto o processo contribui para cada impacto dentro da metodologia selecionada. Oferece também planilhas com todos os dados sobre o balanço de massas calculado.

Estas planilhas possibilitam que cada impacto seja visualizado separadamente e informam quais fluxos, elementares e não elementares, estão ligados a quais impactos. No capítulo 4 são apresentados os gráficos e uma planilha informando quais fluxos elementares contribuem para cada impacto. 


\subsection{Síntese Analítica}

Para guiar o exercício de aplicação da metodologia descrita nos manuais do ILCD de forma clara e didática as informações colhidas no estudo dos textos foram sistematizadas inicialmente em um questionário e posteriormente organizadas em planilhas divididas por fases da aplicação da ACV. Este método facilitou a aplicação dos passos e organizou o estudo.

O método de sistematização da metodologia do ILCD em questionários e planilhas pode contribuir com a facilitação de procedimentos de aplicação da ACV e de avaliação de relatórios apresentados como resultados de ACVs, bem como com o treinamento de profissionais para aplicarem a ferramenta. 


\section{Capítulo 4: Resultados do ICV - AICV.}

A Análise do Impacto do Ciclo de Vida (AICV) foi elaborada baseada nos resultados dos cálculos feitos no software Gabi. O programa apresenta gráficos de valores de acordo com algumas metodologias como o ILCD, CML 2001, RECIPE, entre outros.

Conforme citado no item 2.3 - modelagem do ICV, o ILCD recomenda que antes do cálculo nenhuma categoria de impacto seja descartada e que na fase de avaliação dos resultados as categorias mais representativas sejam selecionadas e trabalhadas.

Para esta seleção foi considerada a norma europeia EN15804:2012+A1:2013, que estipula regras para a elaboração de uma declaração ambiental de produto (EPD), e prevê, baseada na metodologia CML-IA desenvolvida pelo Instituto de Ciências Ambientais da Universidade de Leiden, na Holanda, que para a elaboração do EPD os impactos que devem obrigatoriamente ser considerados são (BRE, 2014):

- Aquecimento Global ou Mudança Climática;

- Destruição do Ozônio;

- Acidificação do solo e da água;

- Eutrofização;

- Criação de Ozônio Fotoquímico;

- Esgotamento de Recursos Abióticos - elementos;

- Esgotamento de Recursos Abióticos - combustíveis fósseis;

Nesta análise de resultados não serão atribuídos pesos diferenciados para as categorias de impacto. O objetivo não é classificar os impactos por importância mas sim analisar a contribuição do processo de produção do painel para cada categoria.

\subsection{Cálculo dos Impactos Ambientais.}

4.1.1 Potencial de Aquecimento Global ou Mudança Climática.

A primeira categoria de impacto apresentada é referente ao potencial de aquecimento global (PAG), ou GWP (Global Warm Potencial), ou ainda potencial de mudança climática. Esta categoria refere-se à mudança na temperatura global causada pelo efeito estufa que acontece devido aos gases liberados na atmosfera 
pela atividade humana, chamados de gases do efeito estufa, como o dióxido de carbono (BRE, 2008).

Segundo a BRE (2008), atualmente existe consenso entre os cientistas que o crescimento das emissões de gases do efeito estufa contribuem de fato com alterações climáticas. O aquecimento global causa distúrbios climáticos, desertificação, aumento do nível dos oceanos e a proliferação de doenças.

Este impacto é expressado em Potencial de Aquecimento Global nos próximos 100 anos e a unidade utilizada é $\mathrm{Kg} \mathrm{CO} 2$ equivalente.

A tabela 15 e o gráfico da figura 26 apresentam os processos com os valores mais representativos. Observa-se que a produção do concreto tem a principal contribuição para o aquecimento global, representando $70,09 \%$ do total. A produção do bloco cerâmico vem em seguida com $29,62 \%$ e a produção do vergalhão de aço, com $8,81 \%$.

Segundo relatório do software o total da contribuição para mudança climática é composto por emissões de recursos materiais renováveis $(14,14 \%)$, emissões inorgânicas para o ar (84,01\%), emissões orgânicas para o ar grupo VOC (Componentes Voláteis Orgânicos) (1,62\%) (Tabela 15).

Tabela 15: Resultados para a categoria de impacto PAG - Potencial de aquecimento global.

\begin{tabular}{|l|r|l|c|}
\hline \multicolumn{3}{|c|}{ Valores para Mudança Climática } \\
\hline Total & 31,9 & $\mathrm{Kg} \mathrm{CO} 2$ eq. & $100 \%$ \\
\hline Concreto & 22,5 & $\mathrm{Kg} \mathrm{CO} 2$ eq. & $70,09 \%$ \\
\hline Bloco cerâmico & 6,26 & $\mathrm{Kg} \mathrm{CO} 2$ eq. & $19,62 \%$ \\
\hline Vergalhão de aço & 2,81 & $\mathrm{Kg} \mathrm{CO}$ eq. & $8,81 \%$ \\
\hline Transporte do vergal hão de aço & 0,0776 & $\mathrm{Kg} \mathrm{CO} 2$ eq. & $0,24 \%$ \\
\hline Transporte do bloco & 0,238 & $\mathrm{Kg} \mathrm{CO} 2$ eq. & $0,75 \%$ \\
\hline Resto & 0,0327 & $\mathrm{Kg} \mathrm{CO}$ eq. & $0,10 \%$ \\
\hline
\end{tabular}




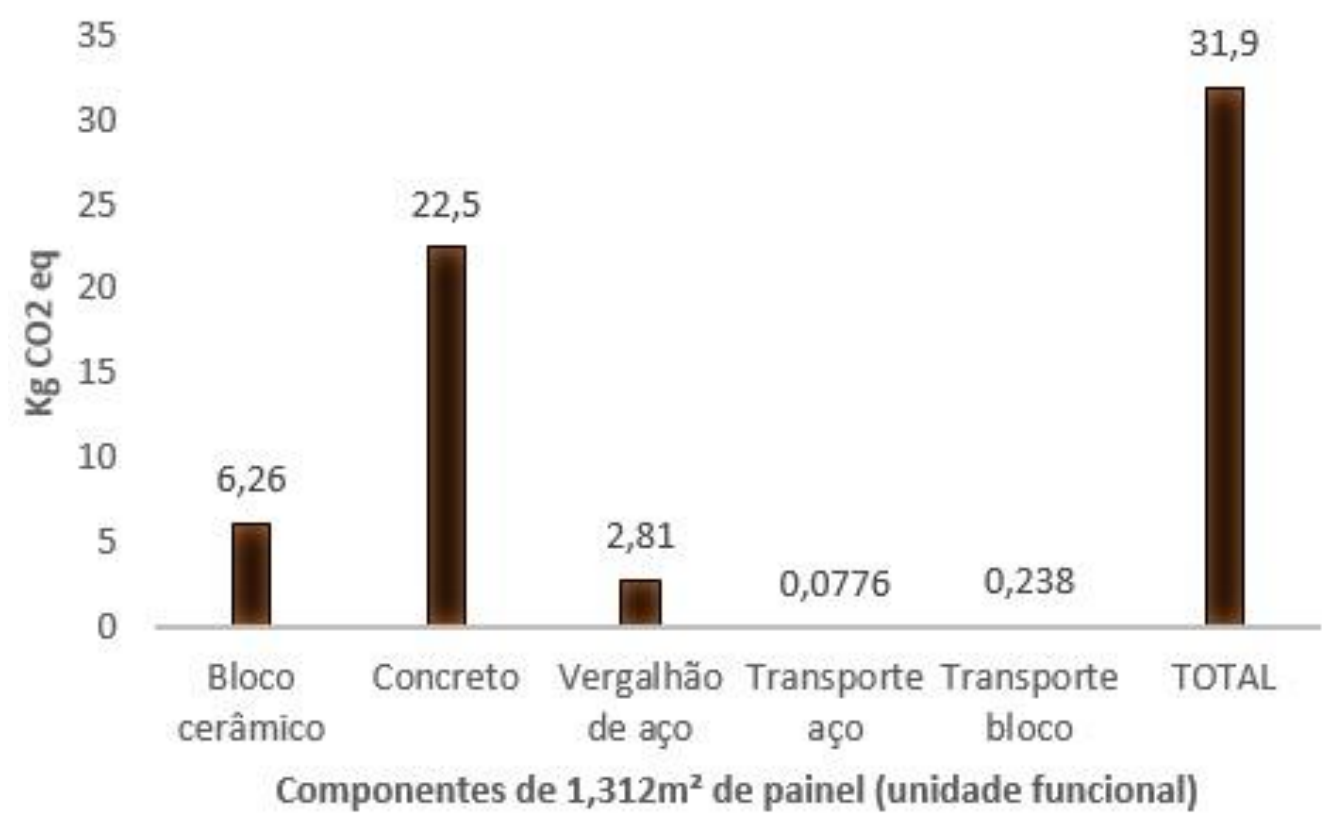

Figura 25: Gráfico de contribuições para o potencial de aquecimento global.

contribuem para PAG - Potencial de aquecimento global.

\begin{tabular}{|l|r|r|}
\hline \multicolumn{3}{|c|}{ Tipo de Contribuições para Impactos Ambientais - GWP } \\
\hline Emissões de recursos materiais renováveis & $4,51 \mathrm{Kg} \mathrm{CO} 2$ eq. & $14,14 \%$ \\
\hline Emissões inorgânicas para o ar & $26,8 \mathrm{Kg} \mathrm{CO} 2$ eq. & $84,01 \%$ \\
\hline Emissões orgânicas para o ar (VOC) & $0,518 \mathrm{Kg} \mathrm{CO} 2$ eq. & $1,62 \%$ \\
\hline TOTAL & $31,9 \mathrm{Kg} \mathrm{CO}$ eq. & $100 \%$ \\
\hline
\end{tabular}

\subsubsection{Depleção da Camada de Ozônio.}

A categoria de impacto Potencial de Depleção da Camada de Ozônio (PDO ou ODP - Ozone Depletion Potencial) refere-se ao dano causado na camada de ozônio pela liberação na atmosfera de gases como o cloro-flúor-carbono (CFC) que, apesar dos danos causados ao meio-ambiente serem amplamente conhecidos, ainda é utilizado em equipamentos de refrigeração e espumas de isolamento.

A camada de ozônio protege a superfície terrestre da incidência direta de raios solares ultravioletas que são agressivos à saúde humana. Esta categoria de impacto mede o potencial de destruição da camada de ozônio de diferentes gases tendo como 
referência o CFC-11. A unidade utilizada para quantificar este impacto é $\mathrm{Kg} \mathrm{R} 11$ equivalente.

Os valores para esta categoria estão listados na tabela 17 e representados no gráfico da figura 27. Segundo o relatório do balanço gerado pelo software o total do potencial deste impacto (2,64E-08 Kg R11eq.) refere-se à emissões orgânicas para o ar (grupo VOC) (Tabela 18).

Observa-se que a produção do vergalhão de aço é o principal contribuinte para a destruição da camada de ozônio no processo estudado, representando 95,07\% do total das emissões.

Tabela 17: Resultados para a categoria de impacto para PDO - Potencial de depleção da camada de ozônio.

\begin{tabular}{|l|r|l|c|}
\hline \multicolumn{3}{|c|}{ Valores para Depleção da Camada de Ozônio } \\
\hline Total & $2,64 \mathrm{E}-08$ & Kg R11 eq. & $100 \%$ \\
\hline Bloco cerâmico & $1,13 \mathrm{E}-09$ & Kg R11 eq. & $4,28 \%$ \\
\hline Diesel do transporte do aço & $6,13 \mathrm{E}-14$ & Kg R11 eq. & $0,0002 \%$ \\
\hline Diesel do transporte do bloco & $1,88 \mathrm{E}-13$ & Kg R11 eq. & $0,0007 \%$ \\
\hline Concreto & $2,01 \mathrm{E}-10$ & Kg R11 eq. & $0,76 \%$ \\
\hline Vergal hão de aço & $2,51 \mathrm{E}-08$ & Kg R11 eq. & $95,08 \%$ \\
\hline
\end{tabular}

Tabela 18: Fluxos que contribuem para PDO - Potencial de depleção da camada de ozônio.

Tipos de Contribuições para Impatos Ambientais - PDO

Emissões orgânicas para o ar (VOC)

2,64E-08 Kg R11 eq.

$100 \%$

TOTAL

2,64E-08 Kg R11 eq.

$100 \%$ 


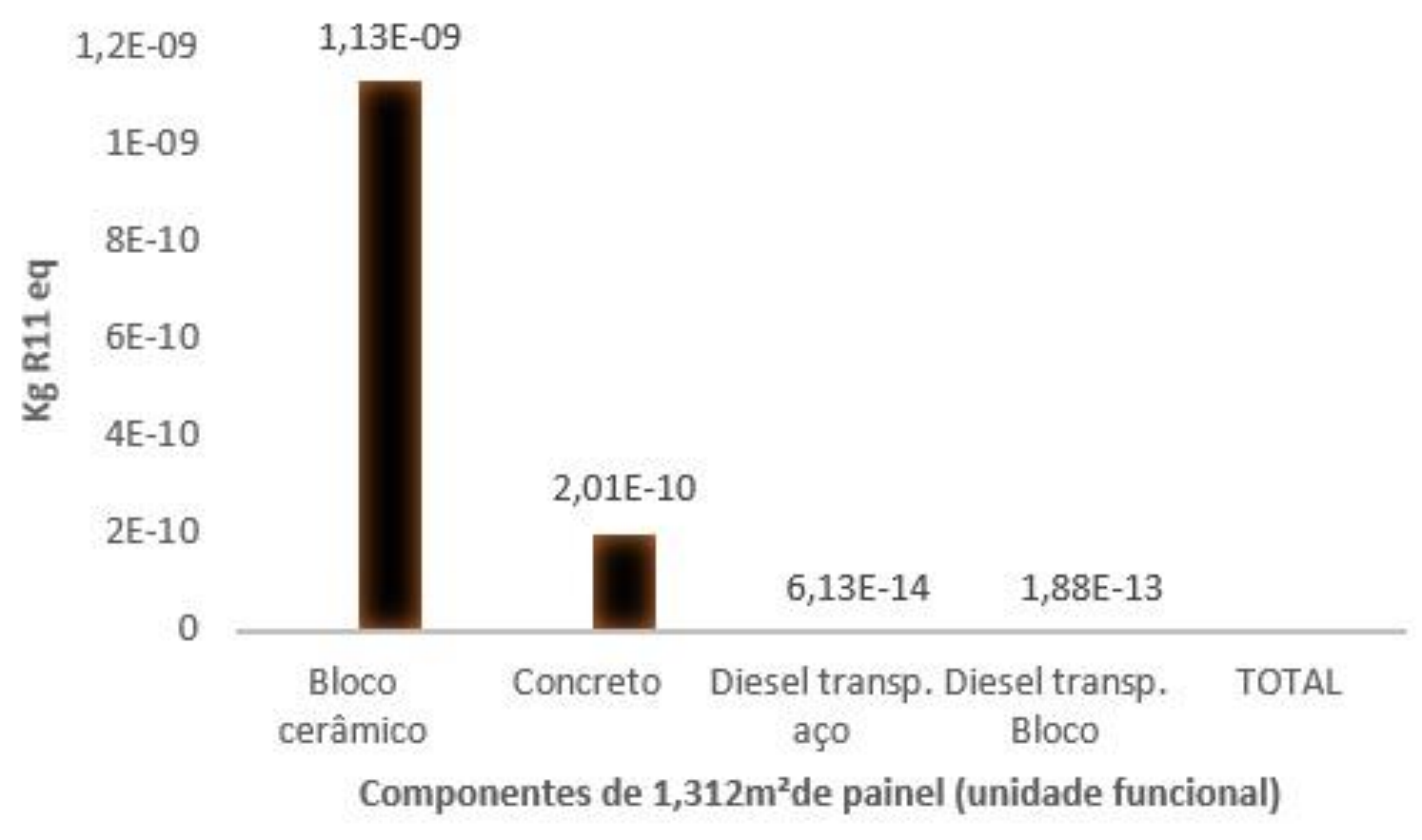

26: Gráfico de contribuições para o potencial de depleção da camada de ozônio.

Figura

\subsubsection{Potencial de Acidificação.}

A categoria de impacto Potencial de Acidificação (PA ou AP - Acidification Potencial) representa o potencial de acidificação das águas presentes no solo e na atmosfera que reagem com gases ácidos como o dióxido sulfúrico e os óxidos de nitrogênio resultantes da queima de combustíveis, trazendo prejuízos para ecossistemas e erodindo materiais. O potencial de acidificação é medido em $\mathrm{Kg}$ de SO2 equivalente (BRE, 2008).

Os valores dos processos mais representativos dentro do sistema estudado estão listados na tabela 19 e representados no gráfico da figura 28.

Observa-se que o concreto é o processo com maior representação nesta categoria de impacto, participando com $66,87 \%$ do total, seguido da produção de vergalhões de aço que representa $16,22 \%$ e da produção do bloco cerâmico que representa $11,77 \%$. 
Tabela 19: Resultados para a categoria de impacto para PA - Potencial de acidificação.

\begin{tabular}{|l|r|l|c|}
\hline \multicolumn{3}{|c|}{ Valores para Acidificação do solo e das águas } \\
\hline Total & $4,92 \mathrm{E}-02$ & Kg SO2 eq. & $100 \%$ \\
\hline Bloco cerâmico & $5,79 \mathrm{E}-03$ & Kg SO 2 eq. & $11,77 \%$ \\
\hline Concreto & $3,29 \mathrm{E}-02$ & Kg SO2 eq. & $66,87 \%$ \\
\hline Vergalhão de aço & $7,98 \mathrm{E}-03$ & Kg SO2 eq. & $16,22 \%$ \\
\hline Transporte do vergalhão de aço & $5,54 \mathrm{E}-04$ & Kg SO2 eq. & $1,13 \%$ \\
\hline Transporte do bloco & $1,69 \mathrm{E}-03$ & Kg SO2 eq. & $3,43 \%$ \\
\hline Resto & $2,67 \mathrm{E}-04$ & Kg SO2 eq. & $0,54 \%$ \\
\hline
\end{tabular}

A contribuição para este impacto refere-se quase que totalmente à emissões inorgânicas para o ar $(99,17 \%)$, mas também resultaram pequenas emissões inorgânicas para a água (0,83\%) e para o solo (0,00000000003\%) (tabela 20).

POTENCIAL DE ACIDIFICAÇÃO

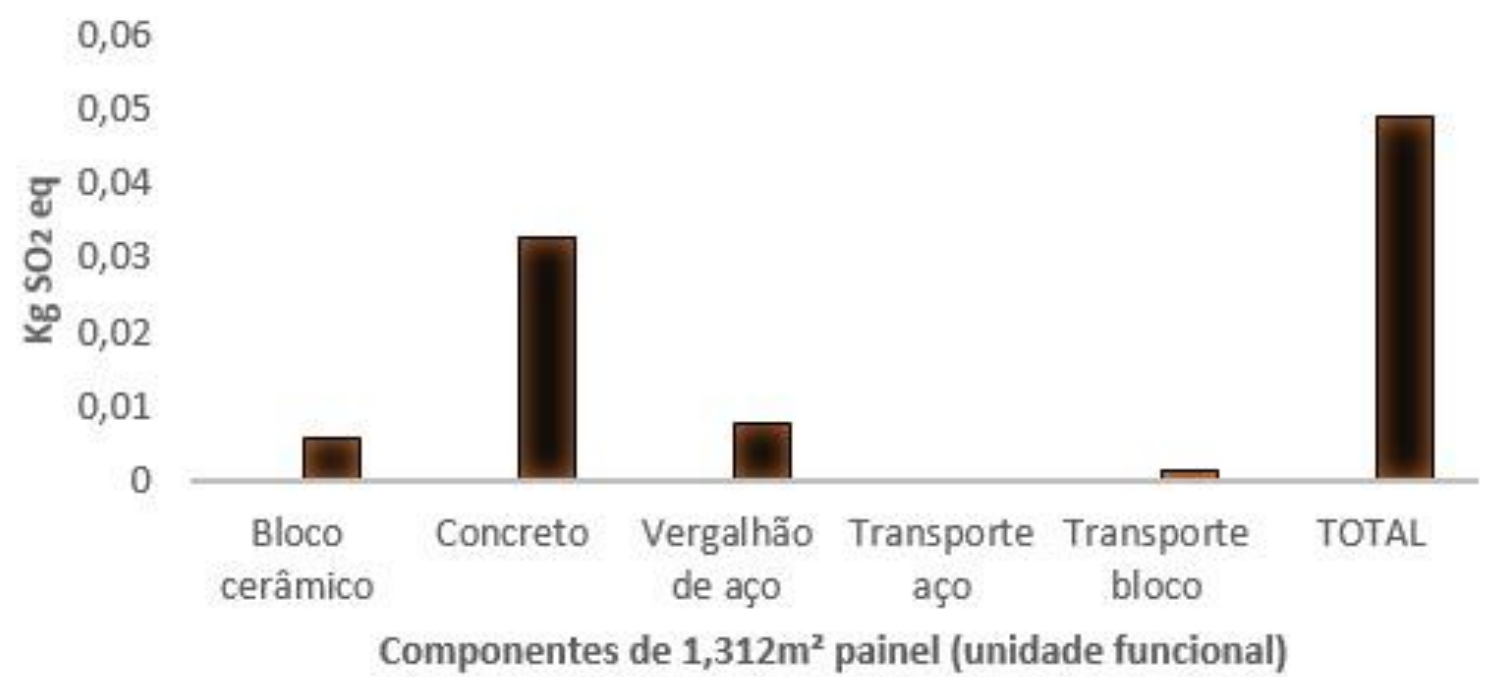

Figura 27: Gráfico de contribuições para o potencial acidificação. 
Tabela 20: Fluxos que contribuem para PA - Potencial de acidificação.

\begin{tabular}{|l|r|l|r|}
\hline \multicolumn{4}{|c|}{ Tipo de Contribuições para Impactos Ambientais - PA } \\
\hline Emissões inorgânicas para o ar & $4,99 \mathrm{E}-02$ & $\mathrm{Kg} \mathrm{SO} 2$ eq. & $99,17 \%$ \\
\hline Emissões inorgânicas para água & $4,17 \mathrm{E}-04$ & $\mathrm{Kg} \mathrm{SO} 2$ eq. & $0,83 \%$ \\
\hline Emissões para o solo & $1,55 \mathrm{E}-14$ & $\mathrm{Kg} \mathrm{SO} 2$ eq. & $0,00000000003 \%$ \\
\hline TOTAL & $5,03 \mathrm{E}-02$ & $\mathrm{Kg} \mathrm{SO} 2$ eq. & $100 \%$ \\
\hline
\end{tabular}

\subsubsection{Potencial de Eutrofização.}

A categoria de impacto Potencial de Eutrofização (PE ou EP - Eutrophication Potencial) refere-se ao aumento da concentração de nitratos e fosfatos na água, que estimula o crescimento exagerado de algas que consomem todo o oxigênio necessário para a vida de outros ecossistemas. Este impacto é causado pela liberação no meio-ambiente de fertilizantes e emissões de $\mathrm{NO}$ x provenientes da queima de combustíveis fósseis. A unidade utilizada é $\mathrm{Kg} \mathrm{PO} 4$ equivalente (BRE, 2008).

Para os impactos relativos ao potencial de eutrofização, os valores seguem listados na tabela 21 e representados no gráfico da figura 29.

Tabela 21: Resultados para a categoria de impacto para PE - Potencial de eutrofização.

\begin{tabular}{|l|r|l|r|}
\hline \multicolumn{3}{|c|}{ Valores para o Potencial de Eutrofização } \\
\hline Total & $8,08 \mathrm{E}-03$ & Kg Fosfato eq. & $100 \%$ \\
\hline Bloco ceramico & $1,28 \mathrm{E}-03$ & Kg Fosfato eq. & $15,84 \%$ \\
\hline Concreto & $5,64 \mathrm{E}-03$ & Kg Fosfato eq. & $69,80 \%$ \\
\hline Vergalhão de aço & $6,33 \mathrm{E}-04$ & Kg Fosfato eq. & $7,83 \%$ \\
\hline Transporte dos blocos aço & $1,18 \mathrm{E}-04$ & Kg Fosfato eq. & $1,46 \%$ \\
\hline Transporte dos blocos cerâmicos & $3,61 \mathrm{E}-04$ & Kg Fosfato eq. & $4,47 \%$ \\
\hline Resto & $4,85 \mathrm{E}-05$ & Kg Fosfato eq. & $0,60 \%$ \\
\hline
\end{tabular}

Observa-se que a produção do concreto é o principal responsável pelo impacto de eutrofização, representando $69,80 \%$, seguido pela produção do bloco cerâmico que representa $15,84 \%$. A produção do vergalhão de aço, o transporte dos vergalhões de aço e o transporte dos blocos também aparecem no gráfico 


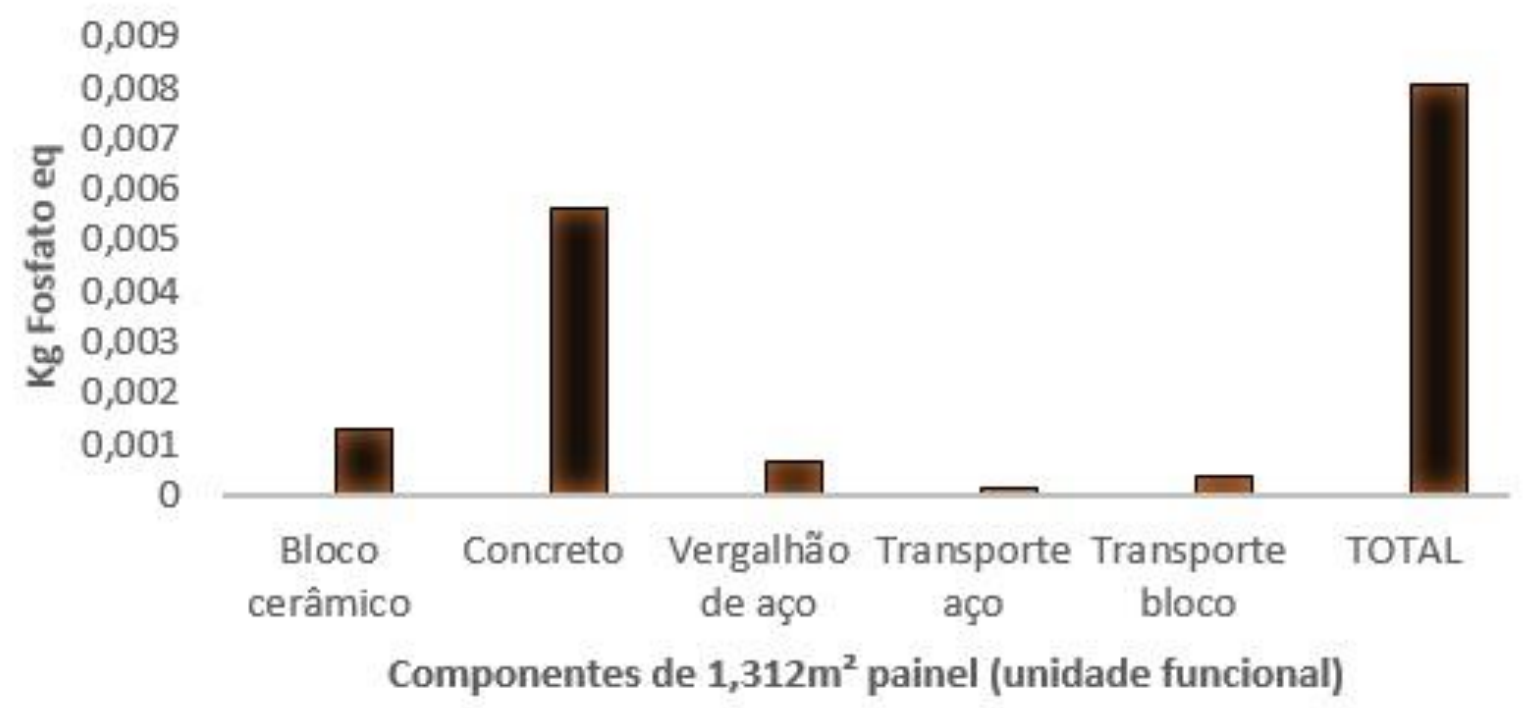

Figura 28: Gráfico de contribuições para potencial eutrofização.

O principal tipo de contribuição para o potencial de eutrofização é de emissões inorgânicas para o ar (92,9\%) conforme tabela 22.

Tabela 22: Fluxos que contribuem para PE - Potencial de eutrofização.

\begin{tabular}{|l|r|l|c|}
\hline \multicolumn{4}{|c|}{ Tipos de Contribuições para Impactos Ambientais - EP } \\
\hline Emissões inorgânicas para o ar & $7,51 \mathrm{E}-03$ & Kg Fosfato eq. & $92,89 \%$ \\
\hline Medidas analíticas para a água doce & $2,61 \mathrm{E}-04$ & Kg Fosfato eq. & $3,23 \%$ \\
\hline Emissões inorgânicas para água doce & $2,69 \mathrm{E}-04$ & Kg Fosfato eq. & $3,33 \%$ \\
\hline Emissões orgânicas para água doce & $3,93 \mathrm{E}-05$ & Kg Fosfato eq. & $0,49 \%$ \\
\hline Emissões para água do mar & $2,63 \mathrm{E}-06$ & Kg Fosfato eq. & $0,03 \%$ \\
\hline Emissões inorgânicas para o solo & $3,24 \mathrm{E}-06$ & Kg Fosfato eq. & $0,04 \%$ \\
\hline TOTAL & $8,09 \mathrm{E}-03$ & Kg Fosfato eq. & $100 \%$ \\
\hline
\end{tabular}

4.1.5 Formação Fotoquímica de Ozônio.

A categoria de impacto Potencial de Formação Fotoquímica de Ozônio (PFFO ou POCP - Photochemical Ozone Creation Potencial) refere-se a formação de ozônio que acontece em atmosferas que contém poluentes como óxidos de nitrogênio (NOx) e compostos orgânicos voláteis (VOCs), na presença de luz solar. O ozônio, quando presente em camadas baixas da atmosfera provoca problemas de saúde, 
principalmente doenças respiratórias. Os VOCs são provocados por solventes e combustíveis (BRE, 2008).

Os dados sobre o potencial de formação fotoquímica de ozônio estão listados na tabela 23 e representados no gráfico da figura 30 .

\section{FORMAÇÃO FOTOQUÍMICA DE OZÔNIO}

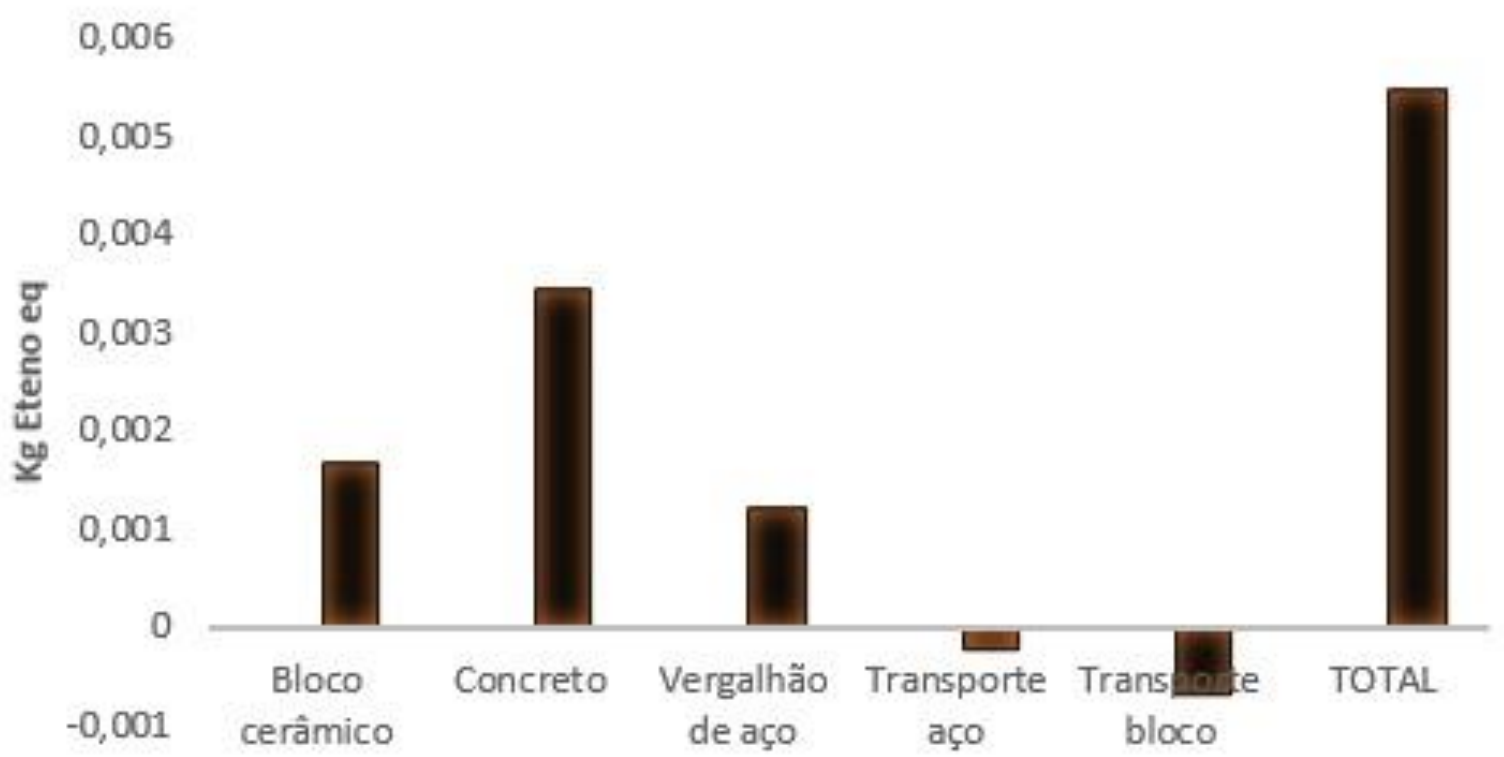

Componentes de $1,312 \mathrm{~m}^{2}$ painel (unidade funcional)

Figura 29: Gráfico de contribuições para o potencial de formação fotoquímica de ozônio.

Observa-se que o processo de produção de concreto é o que mais contribui com a formação fotoquímica de ozônio, participando com $62,91 \%$ do total, seguido pela produção do bloco cerâmico que contribui com 30,36\% e pela produção do vergalhão de aço que contribui com $22,55 \%$. Observa-se ainda que os transportes apresentam valores negativos. Isso acontece porque o processo consome mais dos gases que contribuem para a formação de ozônio do que os liberam na atmosfera. 
Tabela 23: Resultados para a categoria de impacto PFFO - Potencial de formação fotoquímica de ozônio.

\begin{tabular}{|l|r|l|c|}
\hline \multicolumn{3}{|c|}{ Formação Fotoquímica Ozônio } \\
\hline Total & $5,50 \mathrm{E}-03$ & Kg Eteno eq. & $100 \%$ \\
\hline Bloco cerâmico & $1,67 \mathrm{E}-03$ & Kg Eteno eq. & $30,36 \%$ \\
\hline Concreto & $3,46 \mathrm{E}-03$ & Kg Eteno eq. & $62,91 \%$ \\
\hline Vergalhão de aço & $1,24 \mathrm{E}-03$ & Kg Eteno eq. & $22,55 \%$ \\
\hline Transporte do aço & $-2,22 \mathrm{E}-04$ & Kg Eteno eq. & $-4,04 \%$ \\
\hline Transporte dos blocos cerâmicos & $-6,80 \mathrm{E}-04$ & Kg Eteno eq. & $-12,36 \%$ \\
\hline Resto & $3,95 \mathrm{E}-05$ & Kg Eteno eq. & $0,72 \%$ \\
\hline
\end{tabular}

sistema estudado contribui para a formação fotoquímica de ozônio com emissões inorgânicas para o ar e emissões orgânicas para o ar conforme tabela 24.

Tabela 24: Fluxos que contribuem para para PFFO - Potencial de formação fotoquímica de ozônio.

\begin{tabular}{|l|r|l|c|}
\hline \multicolumn{4}{|c|}{ Tipos de Contribuições para Impactos Ambientais - PFFO } \\
\hline Emissões inorgânicas para o ar & $3,36 \mathrm{E}-03$ & Kg Eteno eq. & $61,09 \%$ \\
\hline Emissões orgânicas para o ar (VOC) & $2,14 \mathrm{E}-03$ & Kg Eteno eq. & $38,91 \%$ \\
\hline TOTAL & $5,50 \mathrm{E}-03$ & Kg Eteno eq. & $100 \%$ \\
\hline
\end{tabular}

\subsubsection{Esgotamento de Recursos Abióticos - Elementos.}

Os resultados referentes ao Potencial de Depleção Abiótica (PDA ou ADP Abiotic Depletion Potencial) - elementos estão listados na tabela 25 e representados no gráfico na figura 31 .

Neste caso também a produção do concreto é o principal contribuinte, tendo um valor de contribuição maior que o total (144,76\%), sendo compensado pelo valor negativo da produção do vergalhão de aço (-44,76\%).

O valor do vergalhão de aço é negativo para este impacto porque o processo encontrado no banco de dados do software considera a utilização de resíduos de aço como matéria prima. Sendo assim não considera os impactos da extração da matéria prima na natureza.

O aço é um material altamente reciclável e as indústrias utilizam resíduos como matéria prima. Segundo página da Gerdau, esta medida, além de economizar a extração de recursos naturais, evita a deposição de sucata nos aterros e diminui a quantidade de energia gasta no processo de produção, o que faz com que as emissões de CO2 sejam menores. (http://www.gerdau.com.br/meio-ambiente-esociedade/reciclagem-a-sucata.aspx). 
Tabela 25: Resultados para a categoria de impacto para PDA - Elementos - Potencial de depleção de recursos abióticos - elementos.

\begin{tabular}{|l|r|l|c|}
\hline \multicolumn{4}{|c|}{ Depleção de Recursos Abióticos - Elementos } \\
\hline Total & $2,48 \mathrm{E}-05$ & Kg Sb eq. & $100 \%$ \\
\hline Bloco cerâmico & $5,86 \mathrm{E}-09$ & Kg Sb eq. & $0,02 \%$ \\
\hline Diesel do transporte dos vergalhões de aço & $2,83 \mathrm{E}-09$ & Kg Sb eq. & $0,01 \%$ \\
\hline Diesel do transporte do bloco cerâmico & $8,65 \mathrm{E}-09$ & Kg Sb eq. & $0,03 \%$ \\
\hline Concreto & $3,59 \mathrm{E}-05$ & Kg Sb eq. & $144,76 \%$ \\
\hline Vergalhão de aço & $-1,11 \mathrm{E}-05$ & Kg Sb eq. & $-44,76 \%$ \\
\hline
\end{tabular}

A principal contribuição da produção do painel de blocos cerâmicos e concreto armado para esta categoria de impacto está no consumo de recursos materiais não renováveis conforme mostra tabela 26.

Tabela 26: Fluxos que contribuem para para o Potencial depleção de recursos abióticos - elementos.

\begin{tabular}{|l|r|l|c|}
\hline \multicolumn{3}{|c|}{ Tipos de Contribuições para Impactos Ambientais - PDA - elementos } \\
\hline $\begin{array}{l}\text { Consumo de energia de recursos } \\
\text { não renováveis }\end{array}$ & $2,94 \mathrm{E}-08$ & Kg Sb eq. & $0,12 \%$ \\
\hline $\begin{array}{l}\text { Consumo de elementos não } \\
\text { renováveis }\end{array}$ & $7,25 \mathrm{E}-07$ & Kg Sb eq. & $2,93 \%$ \\
\hline $\begin{array}{l}\text { Consumo de recursos materiais não } \\
\text { renováveis }\end{array}$ & $3,54 \mathrm{E}-05$ & Kg Sb eq. & $143,00 \%$ \\
\hline \multicolumn{2}{|c|}{ Fluxos de Saída } \\
\hline $\begin{array}{l}\text { Consumo de recursos materiais não } \\
\text { renováveis }\end{array}$ & $-1,14 \mathrm{E}-05$ & Kg Sb eq. & $-46,05 \%$ \\
\hline TOTAL & $2,48 \mathrm{E}-05$ & Kg Sb eq. & $100 \%$ \\
\hline
\end{tabular}




\section{POTENCIAL DE ESGOTAMENTO DE RECURSOS ABIÓTICOS - ELEMENTOS}

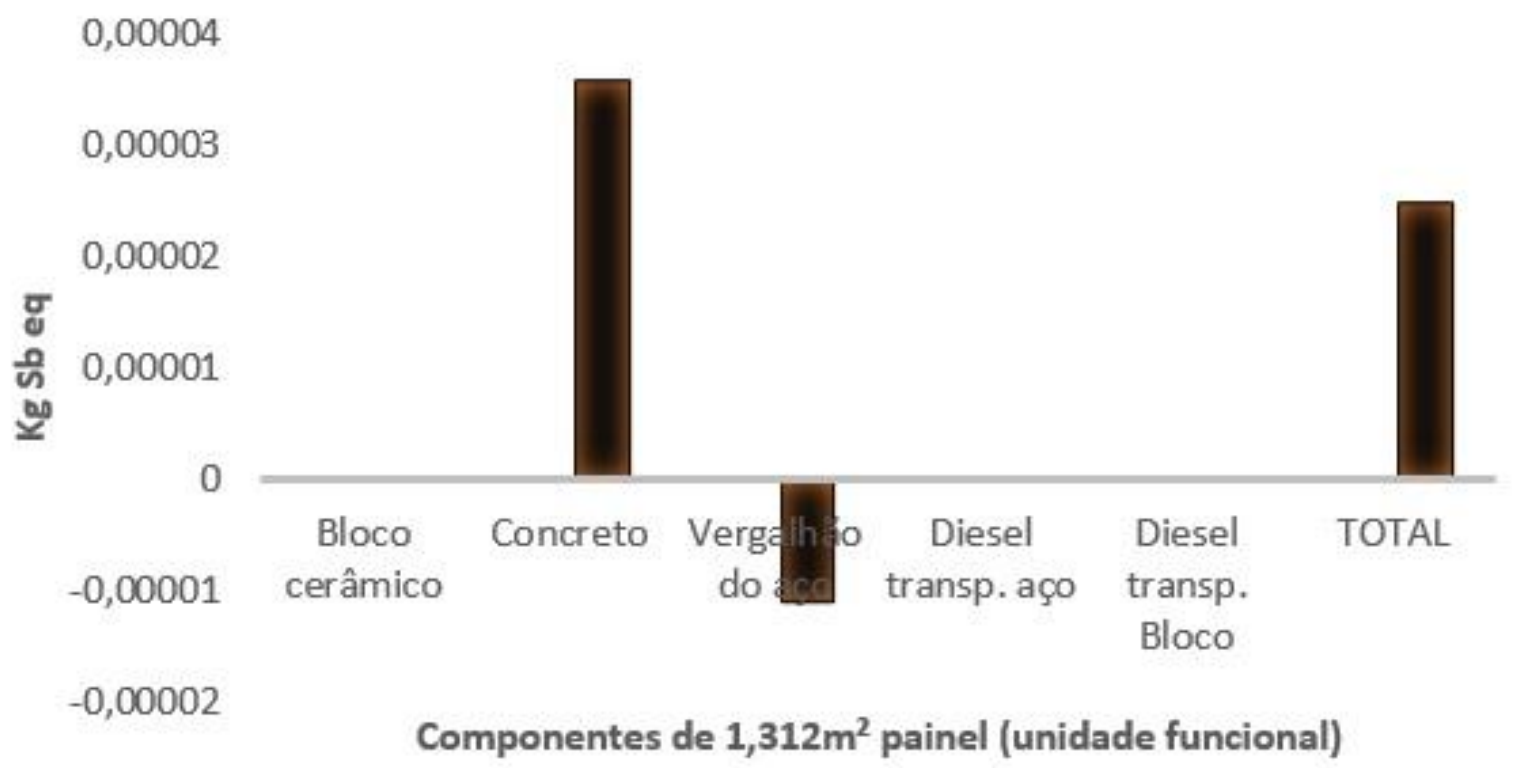

Figura 30: Gráfico de contribuições para o potencial de depleção de recursos abióticos elementos.

\subsubsection{Esgotamento de Recursos Abióticos - Fósseis.}

A categoria de impacto Potencial de Depleção de Recursos Abióticos Fósseis (PDA ou ADP - Abiotic Depletion Potencial - Fóssil) está relacionada ao consumo de combustíveis fósseis, recursos finitos que com a exploração contínua não estarão disponíveis para as próximas gerações.

Os valores para esta categoria estão listados na tabela 27 e representados no gráfico da figura 32 .

Observa-se que neste caso também a produção do concreto apresenta a maior contribuição, representando $65,46 \%$ do total seguido da produção do vergalhão de aço que representa $20,07 \%$ do total. 


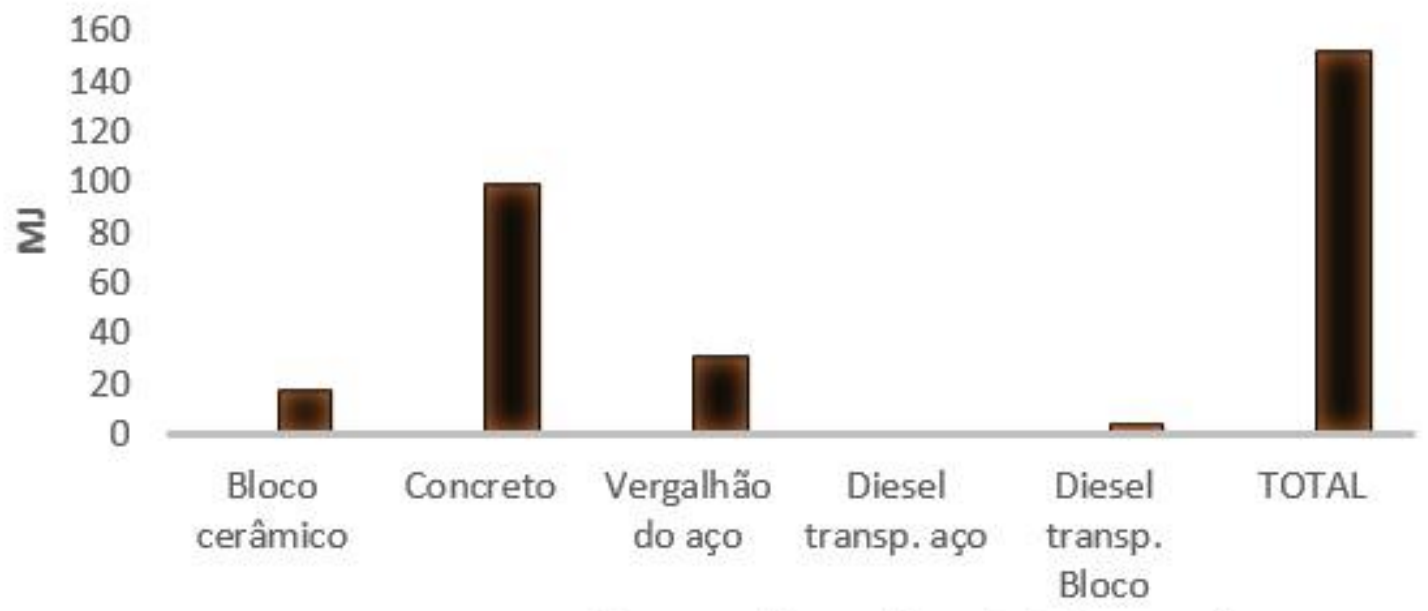

Componentes de $1,312 \mathrm{~m}^{2}$ painel (unidade funcional)

Figura 31: Gráfico das contribuições para o potencial de depleção de recursos abióticos fósseis.

Tabela 27: Resultados para a categoria de impacto para ADP - Elementos - Potencial de depleção de recursos abióticos - elementos.

\begin{tabular}{|l|r|r|c|}
\hline \multicolumn{3}{|c|}{ Depleção de Recursos Abióticos - Fósseis } \\
\hline Total & 152,00 & $\mathrm{MJ}$ & $100 \%$ \\
\hline Bloco cerâmico & 16,80 & $\mathrm{MJ}$ & $11,05 \%$ \\
\hline Diesel combustível do transporte do aço & 1,19 & $\mathrm{MJ}$ & $0,78 \%$ \\
\hline Diesel combustível do transporte do bloco & 3,65 & $\mathrm{MJ}$ & $2,40 \%$ \\
\hline Concreto & 99,50 & $\mathrm{MJ}$ & $65,46 \%$ \\
\hline Vergalhão de aço & 30,50 & $\mathrm{MJ}$ & $20,07 \%$ \\
\hline
\end{tabular}

A principal contribuição para o impacto de esgotamento de recursos abióticos fósseis é o consumo de energia de recursos não renováveis, como mostra a tabela 28. 
Tabela 28: Fluxos para a categoria de impacto potencial de depleção de recursos abióticos - fósseis.

\begin{tabular}{|c|c|c|c|}
\hline \multicolumn{4}{|c|}{ Tipos de Contribuições para Impactos Ambientais - ADP - fóssil } \\
\hline \multicolumn{4}{|c|}{ Fluxos de Entrada } \\
\hline $\begin{array}{l}\text { Consumo de energia de recursos } \\
\text { não renováveis }\end{array}$ & 152 & MJ & $96,82 \%$ \\
\hline $\begin{array}{l}\text { Consumo de recursos materiais não } \\
\text { renováveis }\end{array}$ & 1,17E-03 & MJ & $0,0007 \%$ \\
\hline \multicolumn{4}{|c|}{ Fluxos de Saída } \\
\hline Consumo de energia não renovável & 3,97E-02 & MJ & $0,03 \%$ \\
\hline TOTAL & 157 & MJ & $100 \%$ \\
\hline
\end{tabular}

4.2 Análise dos Resultados dos Cálculos de Impactos.

A metodologia do ILCD recomenda algumas observações importantes na hora de analisar os resultados da AICV, com o objetivo de certificar que o estudo foi desenhado de forma eficiente. Os passos descritos no manual que se aplicam à ACV do painel estudado estão resumidos na tabela 29 e seguidos no desenvolvimento do texto.

Tabela 29: Tabela dos passos identificados pelo ILCD - Fase de Análise dos Resultados dos Cálculos de Impactos. Fonte: EUROPEAN COMMISSION 2010.

\section{Pergunta segundo metodologia do Respostas sobre o painel avaliado ILCD}

\section{FASE DE ANÁLISE DO ICV - AICV}

Os itens significantes abaixo foram

\section{identificados?}

1- estágios do ciclo de vida com maior Sim. 1- produção do concreto; 2contribuição para impactos; produção do vergalhão de aço; 3produção do bloco cerâmico

2- categorias de impactos mais Sim. Gráfico na figura 43 demonstra que representativas; GWP é a categoria mais representativa.

3- escolhas relevantes feitas durante a Utilizar banco de dados do Gabi para os modelagem; processos disponíveis; 2- modelar o processo do bloco com dados do SIMAPRO; 3-modelar o bloco em plano separado; 4-substituição do processo da argila pelo processo da areia;

\section{A modelagem de ICV:}




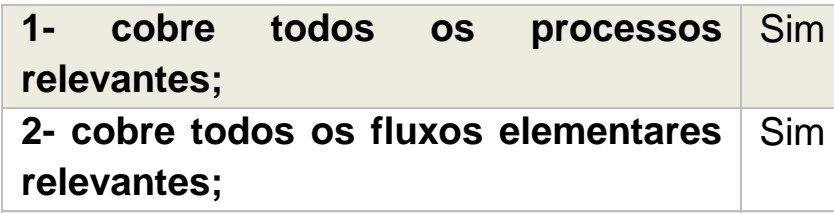

Alguma análise de sensibilidade foi Sim aplicada?

A qualidade dos dados e das fontes Sim são consistentes com os objetivos e escopo do estudo?

\begin{tabular}{l|l|l|}
\hline $\begin{array}{l}\text { As escolhas metodológicas são } \\
\text { consistentes com os objetivos e } \\
\text { escopo do estudo? }\end{array}$ & \\
$\begin{array}{l}\text { A avaliação dos impactos é } \\
\text { consistente com os objetivos e escopo } \\
\text { do estudo? }\end{array}$ & & \\
\hline $\begin{array}{l}\text { Caso existam inconsistencias, suas } \\
\text { relevâncias foram avaliadas? }\end{array}$ & Não existem & \\
\hline $\begin{array}{l}\text { Nas conclusões, existem casos com Não existem } \\
\text { metodologia diferenciada a serem }\end{array}$ & & \\
tratados separadamente? & & \\
\hline $\begin{array}{l}\text { Foi encontrado algum impacto } \\
\text { relevante fora dos previstos pelo }\end{array}$ & avaliada & \\
escopo? & & \\
\hline
\end{tabular}

\subsubsection{Estágios do ciclo de vida mais representativos}

Para identificar os estágios do ciclo de vida com maior contribuição para os impactos, a tabela 30 apresenta quais são os processos que apareceram como mais representativos em cada impacto avaliado. Cada gráfico apresentou o valor total do impacto causado pelo sistema estudado e os cinco processos mais representativos dentro do sistema.

O processo de produção do concreto apareceu em seis das sete categorias de impacto avaliadas como o processo mais representativo, com grande diferença em 
relação aos demais processos, tendo pouca contribuição apenas para a depleção da camada de ozônio.

Considerando todas as categorias de impactos com igual importância, o processo de produção do vergalhão de aço aparece como o segundo processo com a maior soma de contribuições para os impactos ambientais tendo $95,08 \%$ de participação para a depleção da camada de ozônio e participações importantes no potencial de acidificação, potencial de formação de ozônio fotoquímico e potencial de depleção de recursos abióticos fósseis.

Tabela 30: Processos mais representativos de cada impacto.

\begin{tabular}{|c|c|c|c|c|c|c|c|}
\hline \multicolumn{8}{|c|}{ PROCESSOS MAIS REPRESENTATIVOS DE CADA IMPACTO } \\
\hline PAG & $\%$ & PDO & $\%$ & PA & $\%$ & PE & $\%$ \\
\hline concreto & 70,09 & $\begin{array}{l}\text { vergalhão de } \\
\text { aço }\end{array}$ & 95,08 & concreto & 66,87 & concreto & 69,8 \\
\hline bloco cerâmico & 19,62 & $\begin{array}{l}\text { bloco } \\
\text { cerâmico }\end{array}$ & 4,28 & vergalhão de aço & 16,22 & $\begin{array}{l}\text { bloco } \\
\text { cerâmico }\end{array}$ & 15,84 \\
\hline vergalhão de aço & 8,81 & concreto & 0,76 & bloco cerâmico & 11,77 & $\begin{array}{l}\text { vergalhão de } \\
\text { aço }\end{array}$ & 7,83 \\
\hline $\begin{array}{l}\text { transporte do } \\
\text { bloco cerâmico }\end{array}$ & 0,75 & $\begin{array}{l}\text { Diesel do } \\
\text { transp. do } \\
\text { bloco }\end{array}$ & 0,0007 & $\begin{array}{l}\text { transporte do } \\
\text { bloco cerâmico }\end{array}$ & 3,43 & $\begin{array}{l}\text { transporte do } \\
\text { bloco } \\
\text { cerâmico }\end{array}$ & 4,47 \\
\hline $\begin{array}{l}\text { transporte do } \\
\text { vergalhão }\end{array}$ & 0,24 & \begin{tabular}{|l|} 
Diesel do \\
transp. do aço
\end{tabular} & 0,0002 & $\begin{array}{l}\text { transporte do } \\
\text { vergalhão }\end{array}$ & 1,13 & \begin{tabular}{|l} 
transporte do \\
vergalhão
\end{tabular} & 1,46 \\
\hline \multicolumn{8}{|c|}{ PROCESSOS MAIS REPRESENTATIVOS DE CADA IMPACTO } \\
\hline PFFO & $\%$ & \multicolumn{2}{|c|}{ PDA elementos } & $\%$ & \multicolumn{2}{|c|}{ PDA fósseis } & $\%$ \\
\hline concreto & 62,91 & \multicolumn{2}{|l|}{ concreto } & 144,76 & \multicolumn{2}{|r|}{ concreto } & 65,46 \\
\hline vergalhão de aço & 22,55 & \multicolumn{2}{|l|}{ bloco cerâmico } & 0,02 & \multicolumn{2}{|c|}{ vergalhão de aço } & 20,07 \\
\hline bloco cerâmico & 30,36 & \multicolumn{2}{|c|}{$\begin{array}{l}\text { Diesel do transp. do } \\
\text { bloco }\end{array}$} & 0,03 & \multicolumn{2}{|c|}{ bloco cerâmico } & 11,05 \\
\hline $\begin{array}{l}\text { transporte do } \\
\text { vergalhão }\end{array}$ & 12,36 & \multicolumn{2}{|c|}{ Diesel do transp. do aço } & 0,01 & \multicolumn{2}{|c|}{$\begin{array}{c}\text { transporte do bloco } \\
\text { cerâmico }\end{array}$} & 2,4 \\
\hline $\begin{array}{l}\text { transporte da } \\
\text { bloco cerâmico }\end{array}$ & 4,04 & \multicolumn{2}{|l|}{ vergalhão de aço } & $-44,76$ & \multicolumn{2}{|c|}{$\begin{array}{l}\text { transporte do } \\
\text { vergalhão }\end{array}$} & 0,78 \\
\hline
\end{tabular}

Onde:

PAG - Potencial de Aquecimento Global ou Mudança Climática;

PDO - Potencial de Depleção de Ozônio;

PA - Potencial de Acidificação;

PE - Potencial d Eutrofização;

PDA - Potencial de Depleção de Recursos Abióticos;

FFO - Potencial de Formação de Ozônio Fotoquímico. 
O bloco cerâmico ocupa a terceira posição, tendo participação importante no potencial de aquecimento global, potencial de eutrofização e potencial de formação de ozônio fotoquímico.

Sendo assim, dentro no sistema estudado concluímos que o processo de produção do concreto é o estágio do ciclo de vida que tem maior contribuição para os impactos, seguido do processo de produção do vergalhão de aço e do bloco cerâmico.

4.2.2 Categorias de impacto mais representativas

O software Gabi 6 Education possibilita a elaboração de um gráfico normalizado que compara as categorias de impacto de todos os materiais considerados no processo. O programa oferece opções de metodologias de normalização. Para a elaboração do gráfico abaixo (figura 33) foi utilizada a da metodologia do CML 2001 - novembro de 2010, a mesma utilizada para a seleção dos impactos a serem considerados no estudo.

Os impactos com valores representativos estão representados no gráfico, sendo que o Potencial de Depleção de Recursos Abióticos (ADP) elementos e fósseis estão condensados em apenas uma barra.

Siglas no gráfico (figura 33 ):

PAG - Potencial de Aquecimento Global ou Mudança Climática;

PA - Potencial de Acidificação;

PE - Potencial de Eutrofização;

PDA - Potencial de Depleção de Recursos Abióticos;

FFO - Potencial de Formação de Ozônio Fotoquímico. 


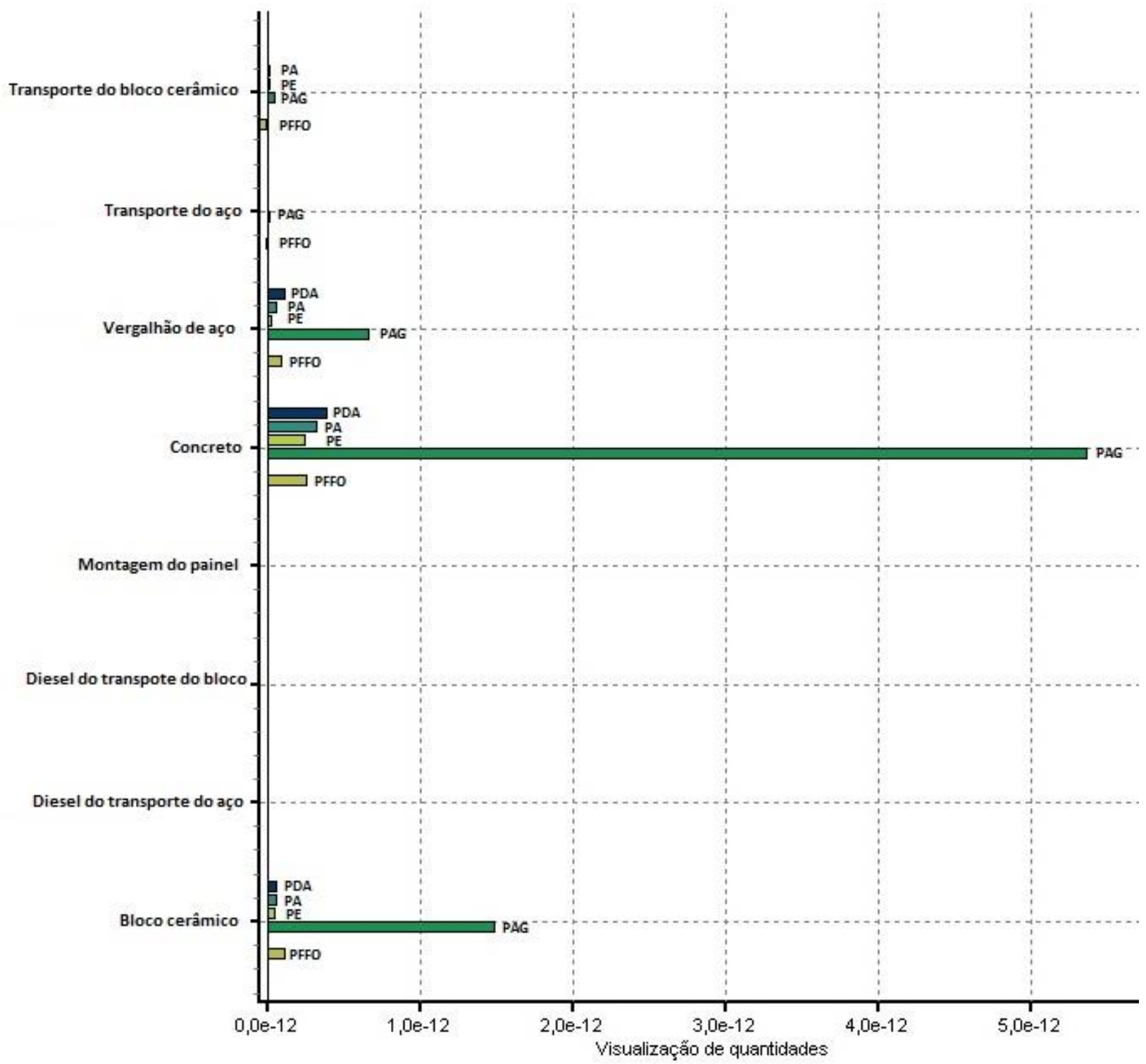

Figura 32: Categorias de impactos mais representativas segundo normalização do CML 2001.

Observa-se no gráfico que o potencial de aquecimento global ou mudança climática (PAG) é a categoria de impacto mais representativa pois tem grande representação na produção do concreto, do vergalhão de aço e do bloco cerâmico.

A depleção de recursos abióticos (PDA) aparece como segunda categoria de impacto mais representativa, mas com diferença muito grande em relação ao PAG. Atrás da PDA, mas muito próximas, estão as categorias que medem o potencial de acidificação (PA) e o potencial de eutrofização (PE). 
4.2.3 Escolhas relevantes durante a modelagem

As escolhas importantes que foram feitas durante a modelagem podem ser resumidas:

- Ao uso dos processos presentes no banco de dados do software Gabi 6 quando disponíveis;

- À modelagem manual do processo do bloco cerâmico baseado nas informações contidas no processo do software simapro 8;

- À modelagem do processo do bloco em um plano separado, o que gerou resultados totais para o processo do bloco cerâmico, seguindo o formato os resultados dos demais processos retirados do banco de dados;

- À substituição, na modelagem do processo do bloco cerâmico, do processo de extração da argila, não existente do banco de dados do software, pelo processo de extração de areia, para obter um resultado aproximado;

\subsubsection{Precisão e qualidade dos dados}

A modelagem do ICV cobre todos os processos existentes dentro do sistema e todos os fluxos elementares identificados nos bancos de dados. O limites do sistema planejados foram respeitados.

A precisão dos dados primários é alta pois são baseados em medições e projetos. Os dados secundários são classificados como sendo de boa qualidade pelo banco de dados do software, mas por serem na maioria dos casos dados internacionais, apesar de apresentarem valores precisos não apresentarão resultados precisos, devido às diferenças regionais.

Dentro do processo do bloco cerâmico, os valores utilizados para as distâncias dos fornecedores até a fábrica são genéricos e por isso são objetos da análise de sensibilidade.

A qualidade dos dados são consistentes com o objetivo e escopo do estudo, seria ideal que fossem encontrados mais dados referentes ao Brasil para atingir uma 
melhor qualidade nos resultados, mas era previsto que dados brasileiros não estariam amplamente disponíveis.

As escolhas metodológicas e a análise dos resultados aconteceram conforme as previstas nas fases de objetivo e escopo do estudo, não gerando nenhuma inconsistência, nenhuma necessidade de utilização de metodologia diferenciada e a relevância dos impactos não foi avaliada.

4.3 Análise de sensibilidade.

4.3.1 Sensibilidade à distância percorrida.

Conforme definido no objetivo do estudo, a intenção foi trabalhar com dados secundários quando relativos aos processos dos materiais que compõe o painel. $\mathrm{Na}$ montagem do processo do bloco cerâmico, com dados retirados do programa SimaPro 8 , os dados para as distâncias entre os fornecedores e a fábrica foram estimados.

Os resultados apresentados consideram uma distância média de $200 \mathrm{Km}$. Para ser possível avaliar quais diferenças nos resultados serão encontradas caso os fornecedores localizem-se a distâncias maiores os resultados foram recalculados considerando $500 \mathrm{Km}$ e $1000 \mathrm{Km}$ (tabela 31 ).

Tabela 31: Processos mais representativos de cada impacto.

\begin{tabular}{|c|c|c|c|c|c|c|c|}
\hline \multirow[b]{2}{*}{ DISTÂNCIA } & \multicolumn{7}{|c|}{ CATEGORIAS DE IMPACTO } \\
\hline & PAG & PDO & PA & PE & PFFO & PDA-el ements & PDA-fóssil \\
\hline PERCORRIDA & $\mathrm{Kg} \mathrm{CO} 2$ eq. & Kg R11 eq. & Kg SO2 eq. & Kg Fosfato eq. & Kg Eteno eq. & Kg Sb eq. & MJ \\
\hline $200 \mathrm{Km}$ & 31,9 & $2,64 \mathrm{E}-08$ & $4,92 \mathrm{E}-02$ & $8,08 \mathrm{E}-03$ & $5,50 \mathrm{E}-03$ & $2,48 \mathrm{E}-05$ & 152 \\
\hline $500 \mathrm{Km}$ & 32,9 & $2,64 \mathrm{E}-08$ & $5,65 \mathrm{E}-02$ & 9,60E-03 & $3,02 \mathrm{E}-03$ & $2,48 \mathrm{E}-05$ & 165 \\
\hline $1000 \mathrm{Km}$ & 33,9 & $2,64 \mathrm{E}-08$ & $6,38 \mathrm{E}-02$ & $1,11 \mathrm{E}-02$ & $5,00 E-04$ & $2,49 E-05$ & 180 \\
\hline
\end{tabular}

Onde:

PAG - Potencial de Aquecimento Global ou Mudança Climática;

PDO - Potencial de Depleção de Ozônio;

PA - Potencial de Acidificação;

PE - Potencial de Eutrofização;

PDA - Potencial de Depleção de Recursos Abióticos;

FFO - Potencial de Formação de Ozônio Fotoquímico.

Das categorias consideradas, duas não sofreram alteração: o potencial de esgotamento de ozônio e o potencial de esgotamento de recursos abióticos - 
elementos. A categoria potencial de formação fotoquímica de ozônio teve resultado negativo, o que significa que o processo com distâncias maiores consomem mais ozônio das camadas da atmosfera onde ele é prejudicial.

Tabela 32: Processos mais representativos de cada impacto.

\begin{tabular}{|l|r|r|r|r|r|r|r|}
\hline \multirow{2}{*}{$\begin{array}{c}\text { DISTÂNCIA } \\
\text { PERCORRIDA }\end{array}$} & \multicolumn{5}{|c|}{ CATEGORIAS DE IMPACTO - AUMENTO EM \% EM RELAÇÃO AOS 200Km } \\
\cline { 2 - 7 } & PAG & PDO & PA & PE & PFFO & DPA-elements & DPA-fóssil \\
\hline $500 \mathrm{Km}$ & $+3,1 \%$ & $0 \%$ & $+14,83 \%$ & $+18,8 \%$ & $-45 \%$ & $0 \%$ & $+8,55 \%$ \\
\hline $1000 \mathrm{Km}$ & $+6,27 \%$ & $0 \%$ & $+29,67 \%$ & $+37,37 \%$ & $-90,9 \%$ & $0 \%$ & $+18,42 \%$ \\
\hline
\end{tabular}

A tabela 32 mostra as alterações nos resultados em porcentagem, assim é possível identificar para quais categorias o impacto relativo ao transporte é mais representativo. Os gráficos apresentados na figura 34 facilitam a percepção do aumento relativo aos impactos.

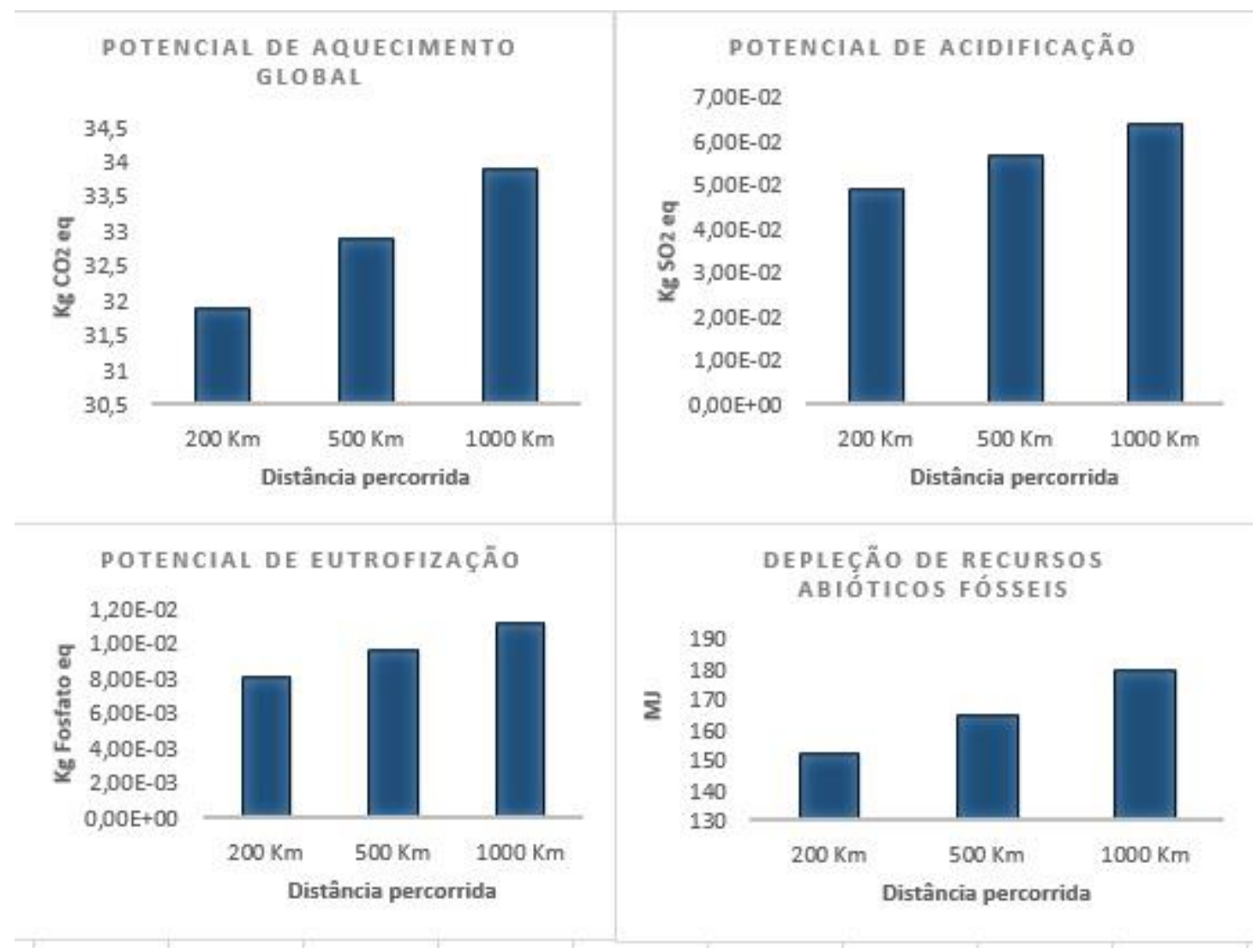

Figura 33: Gráficos que demonstram as alterações nos impactos relacionadas às distâncias percorridas. 
Observa-se que o potencial de acidificação, o potencial de eutrofização e o consumo de recursos abióticos fósseis apresentam grande crescimento em relação ao aumento da distância percorrida, isso porque estas categorias de impactos estão diretamente relacionadas à queima de combustíveis fósseis.

\subsubsection{Sensibilidade à alteração da fonte de dados}

Uma das opções adotadas na modelagem da ACV do painel de blocos cerâmicos e concreto armado foi a utilização dos dados relativos aos materiais que compõe o painel: aço, blocos cerâmicos e concreto armado, presentes no banco de dados do software Gabi 6 Education.

O aço e os blocos cerâmicos utilizados na montagem do painel estudado são materiais provenientes de outras indústrias com processos produtivos complexos, porém o concreto utilizado no painel é feito no canteiro de obras, misturado na betoneira.

Sendo assim, foi possível durante a visita ao canteiro de obras coletar dados sobre os materiais, a dosagem utilizada e sobre a betoneira sendo possível modelar no Gabi 6 Educational um processo para a produção do concreto utilizando as dosagens de componentes fiéis ao executado no canteiro de obras e considerando a fonte energética brasileira, a hidrelétrica.

Nesta análise de sensibilidade o processo do concreto do banco de dados do software, que é um dado alemão, foi substituído pelo processo modelado de acordo com os dados colhidos no local e os resultados desta substituição são apresentados abaixo. São resultados referentes à modelagem padrão, com a distância percorrida pelos materiais considerada $200 \mathrm{Km}$.

A tabela 33 mostra a alteração nos resultados para os impactos relativos ao processo de produção do painel em estudo. 
Tabela 33: Alteração dos valores devido à alteração dos dados do processo do concreto.

\begin{tabular}{|c|c|c|c|c|c|c|c|}
\hline \multirow{2}{*}{$\begin{array}{c}\text { PROCESSO } \\
\text { DO }\end{array}$} & \multicolumn{7}{|c|}{ CATEGORIAS DE IMPACTO RELATIVAS À CONSTRUÇÃO DO PAINEL } \\
\hline & PAG & PDO & PA & PE & PFFO & PDA-elements & PDA-fóssil \\
\hline CONCRETO & $\mathrm{Kg} \mathrm{CO} 2$ eq. & Kg R11 eq. & Kg SO2 eq. & Kg Fosfato eq. & Kg Eteno eq. & $\mathrm{Kg} \mathrm{Sb}$ eq. & MJ \\
\hline BANCO DE & & & & & & & \\
\hline DADOS GABI & 31,9 & $2,64 \mathrm{E}-08$ & $4,92 \mathrm{E}-02$ & $8,08 \mathrm{E}-03$ & $5,50 \mathrm{E}-03$ & $2,48 \mathrm{E}-05$ & 152 \\
\hline COLETA DE & & & & & & & \\
\hline DADOS OBRA & 40,03 & $1,39 \mathrm{E}-06$ & $1,07 \mathrm{E}-01$ & $1,47 \mathrm{E}-02$ & $3,36 \mathrm{E}-03$ & $3,42 \mathrm{E}-05$ & 200 \\
\hline
\end{tabular}

Tabela 34: Acréscimo em porcentagem nos impactos avaliados com a alteração dos dados do concreto.

\begin{tabular}{|c|c|c|c|c|c|c|c|}
\hline \multirow{2}{*}{$\begin{array}{l}\text { PROCESSO } \\
\text { DO } \\
\text { CONCRETO }\end{array}$} & \multicolumn{7}{|c|}{ CATEGORIAS DE IMPACTO - AUMENTO EM \% EM RELAÇÃO AO BANCO DE DADOS DO GABI 6} \\
\hline & PAG & PDO & PA & $\mathrm{PE}$ & PFFO & DPA-el ements & DPA-fóssil \\
\hline COLETA DE & & & & & & & \\
\hline DADOS OBRA & $+20 \%$ & $+98 \%$ & $+54 \%$ & $+45 \%$ & $-39 \%$ & $+27 \%$ & $+24 \%$ \\
\hline
\end{tabular}

A tabela 34 mostra o aumento percentual de cada impacto com a alteração dos dados relativos ao processo do concreto. Seis dos sete impactos avaliados tiveram os resultados aumentados com a alteração dos dados. Apenas o potencial de impacto de formação fotoquímica de ozônio teve seu valor reduzido.

Observa-se que os aumentos percentuais são consideráveis, o que permite concluir que neste estudo a alteração da fonte de dados teve grande interferência nos resultados finais. 

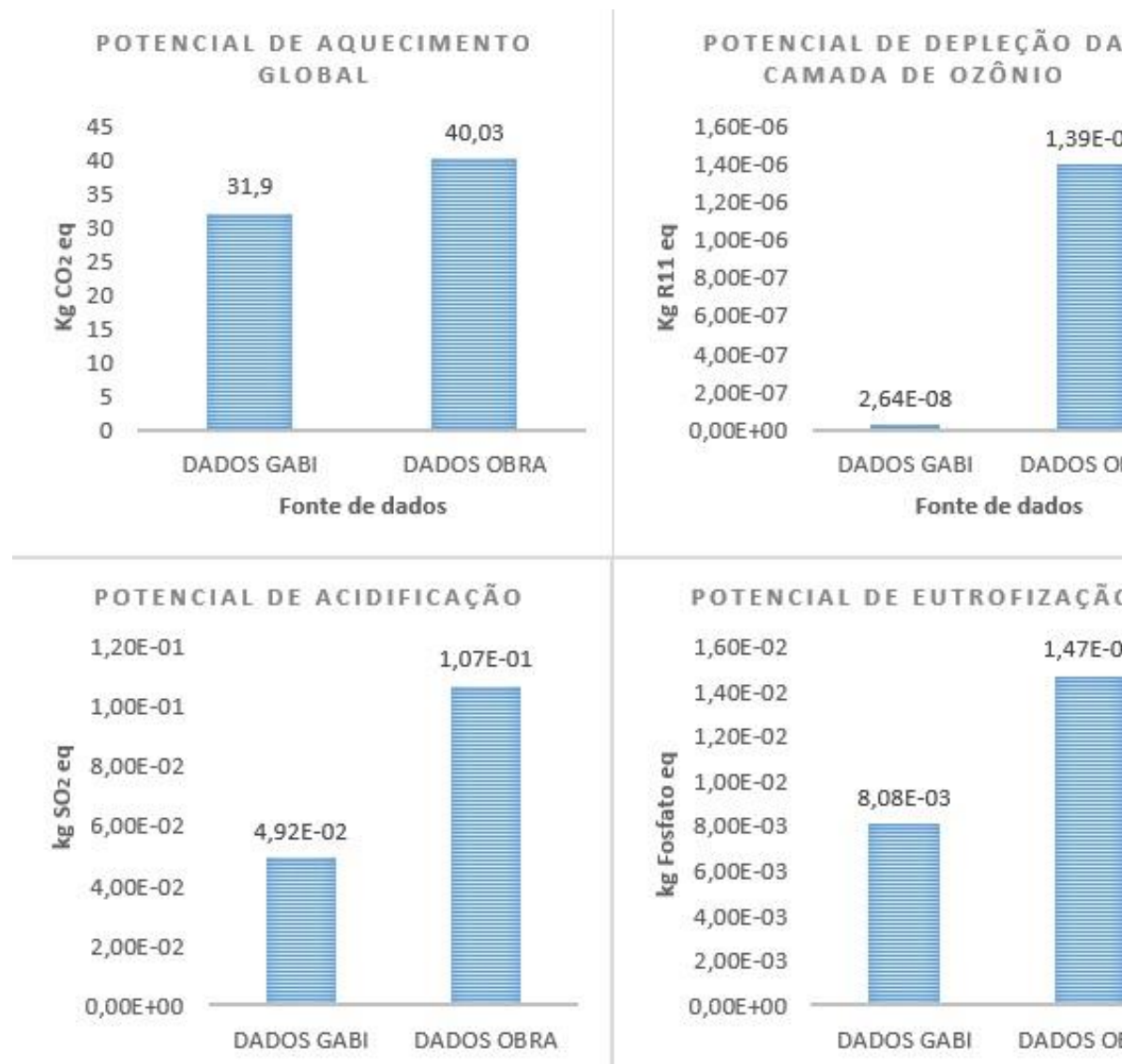

Fonte de dados

$1,39 \mathrm{E}-06$

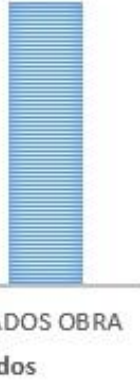

POTENCIAL DE EUTROFIZAÇÃO

$1,60 \mathrm{E}-02 \quad 1,47 \mathrm{E}-02$

$1,40 \mathrm{E}-02$

$1,20 \mathrm{E}-02$

ํำ $1,00 \mathrm{E}-02$

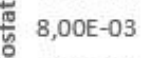

$6,00 \mathrm{E}-03$

$4,00 E-03$

$2,00 \mathrm{E}-03$

$0,00 E+00$

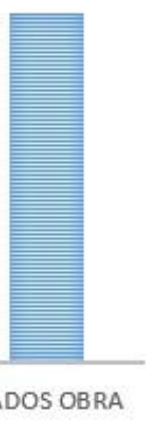

Fonte de dados

Figura 34: Diferença nos resultados dos cálculos dos impactos com a alteração da fonte de dados sobre o concreto. 
As figuras 35 e 36 mostram a alteração dos valores no formato de gráfico.

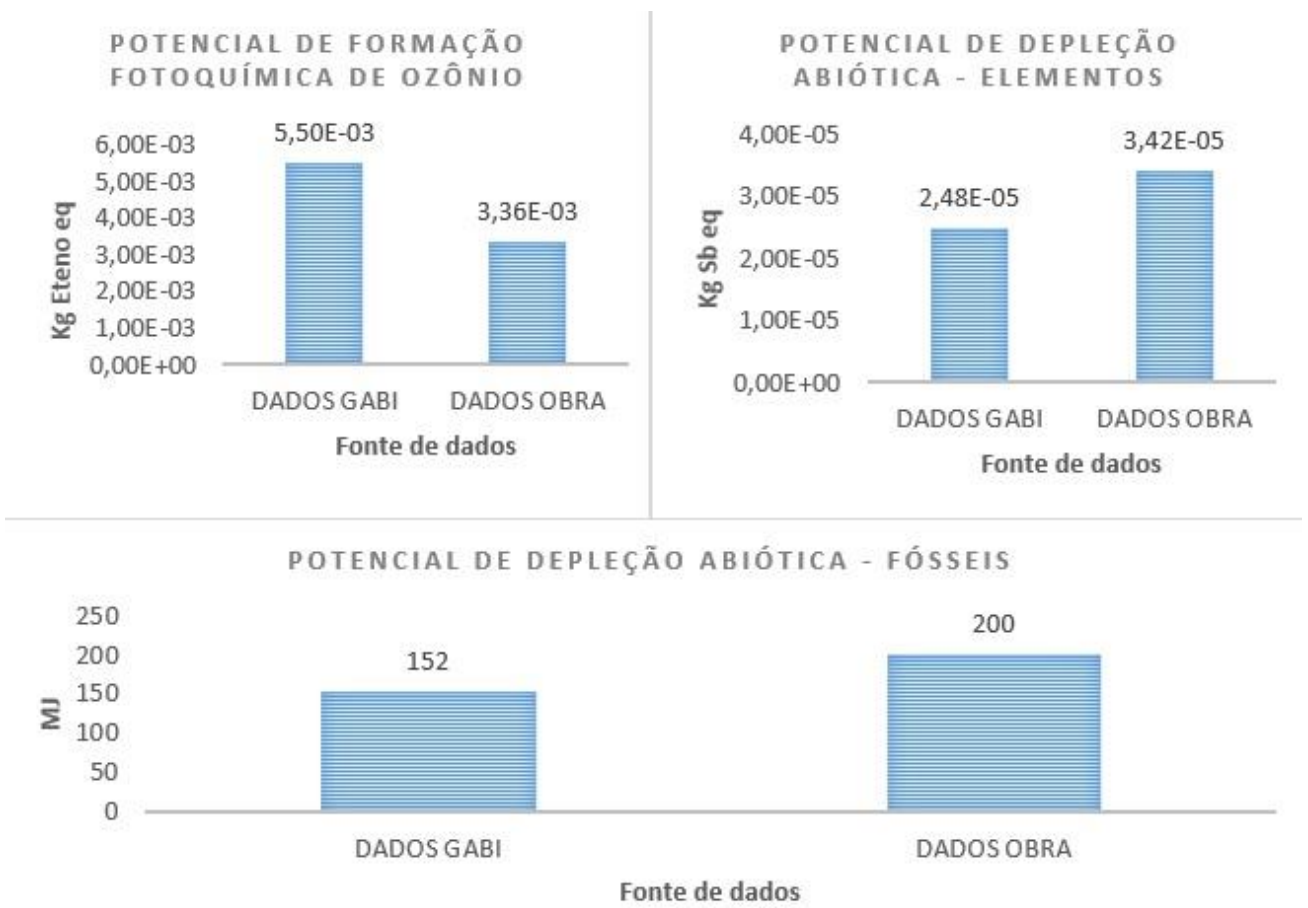

Figura 36: Diferença nos resultados dos cálculos dos impactos com a alteração da fonte de dados sobre o concreto - continuação. 


\section{Considerações Finais}

Para atender os objetivos estabelecidos neste estudo de exercitar a aplicação da metodologia do ILCD para realizar a ACV do painel pré-moldado de blocos cerâmicos e concreto armado, foi desenvolvido um método de sistematização da metodologia em questionários e depois planilhas que facilitaram e organizaram o desenvolvimento do trabalho.

Os resultados da pesquisa permitem fazer considerações sobre a ACV e a aplicação da metodologia do ILCD, identificando benefícios do método

Com os resultados dos cálculos elaborados no software pode-se verificar que a principal contribuição é para a categoria de impacto PAG (Potencial de Aquecimento Global). Esta é a categoria mais representativa para os processos de todos os componentes do painel e com valores muito altos para o processo do concreto.

Os fatores que contribuem para o PAG são majoritariamente as emissões de dióxido de carbono para o ar, representando $85,9 \%$ de todas as emissões referentes a esta categoria de impacto.

Do total de emissões que contribuem para o PAG o processo do concreto contribui com $77,1 \%$, contra $15,5 \%$ do processo do bloco e $7,1 \%$ do processo do aço. Dos $77,1 \%$ de contribuição do concreto $75,7 \%$ são referentes a emissões de dióxido de carbono para o ar.

As demais categorias de impacto são bem menos expressivas que o PAG, mas vale salientar que o processo de produção do concreto contribui com $98,1 \%$ do PDO (Potencial de Depleção da Camada de Ozônio), 84,8\% do PA (Potencial de Acidificação), 83,4\% do PE (Potencial de Eutrofização), 39,1\% do PFFO (Potencial de Formação Fotoquímica de Ozônio), 99,4\% do consumo de recursos abióticos elementos e $73,9 \%$ do consumo de recursos abióticos fósseis.

Com relação ao consumo de energia, o processo do concreto representa $74 \%$ do consumo total, sendo que toda energia consumida refere-se à energias não renováveis, contra $7,64 \%$ do bloco cerâmico e 16,2\% do vergalhão de aço.

Estes resultados podem ser justificados dentro do processo do painel de blocos cerâmicos e concreto armado quando considera-se que aproximadamente 
$87,5 \%$ da massa do painel é composta por concreto, apesar do volume do concreto ser de aproximadamente o dobro do volume dos blocos cerâmicos (volume do concreto: $0,094 \mathrm{~m}^{3} \times$ volume dos blocos $0,048 \mathrm{~m}^{3}$ ).

$\mathrm{Na}$ apresentação do produto passa-se a impressão que os painéis são formados principalmente por blocos cerâmicos mas, em relação à massa, o concreto é o principal componente, e como a unidade de medida para o cálculo da ACV é massa, é esperado que ele apresente as maiores contribuições.

Também por esta razão, quando pensa-se em soluções para possíveis melhorias no desempenho ambiental do painel estudado, as intervenções no componente concreto prometem ser as mais eficientes.

Estudos que resultem em um painel semelhante com a utilização de uma menor quantidade de concreto, ou estudos sobre substituições nos componentes do concreto que possibilitem a diminuição dos seus impactos são sugestões que podem resultar em painés mais eficientes do ponto de vista ambiental.

Com relação às análises de sensibilidades, a primeira analisa a interferência nos resultados da ACV da distância percorrida pelos componentes do bloco cerâmico até chegarem à fabrica. Isto poque o estudo considerou dados primários para as distâncias percorridas pelos componentes do painel até o canteiro de obras, mas considerou dados estimados para os componentes do bloco cerâmico e a análise de sensibilidade veio avaliar a sensibilidade desta estimativa.

Os resultados apresentados em percentuais na tabela 32 página 107 demonstram que há uma interferência significativa do aumento da distância percorrida pelos materiais nos números finais, resultando em impactos maiores na maioria dos casos, chegando a 37,37\% para o PA (Potencial de Acidificação). A única categoria de impacto que sofreu redução foi a PFFO (Potencial de Formação Fotoquímica de Ozônio), conforme apresentado no item 4.3.1 do capítulo 4.

A segunda análise de sensibilidade analisa a interferência da alteração da fonte de dados. O processo do concreto do banco de dados do programa Gabi 6 Educational, que era um dado alemão, foi substituído por um processo montado com dados coletados na obra. 
As diferenças nos resultados também foram bastante significativas conforme demonstrado em percentuais na tabela 34 na página 109. O PDO (Potencial de Depleção da Camada de Ozônio) teve aumento de $98 \%$.

Estas análises demonstram o quanto os resultados são sensíveis aos dados utilizados e que ter atenção à qualidade dos dados e à utilização da maior quantidade de dados primários aproxima os resultados da realidade.

Sobre a aplicação da metodologia do ILCD e a realização da ACV algumas considerações são possíveis de serem feitas.

Entre as diversas metodologias, baseadas nas normas ISO 14040 e 14044, que detalham o processo de aplicação da ferramenta de ACV, o Manual do International Reference Life Cicle Data System (ILCD) foi selcionado como método de aplicação a ser seguido, pois é a metodologia utilizada pelo Programa Brasileiro de Avaliação do Ciclo de vida (PBACV).

O manual consiste em uma série de documentos técnicos, que orientam a prática da ACV na indústria e no governo, e que cobrem todos os passos necessários para a realização de qualquer tipo de ACV (WOLF et al, 2012).

A ACV é uma ferramenta abrangente, os processos produtivos dos vários objetos de estudo possíveis são diversos e englobam situações e cenários específicos. Também variam o público-alvo, os agentes, as finalidades dos estudos, etc. Por esta razão os manuais são extensos e seus procedimentos muitas vezes avançam e retornam nos passos propostos dependendo das situações.

Diante desde cenário, e com o objetivo de nortear a aplicação dos passos e não deixar passar nenhuma informação importante, foi elaborado o questionário (Anexo 2) com a seleção dos passos propostos no manual que dizem respeito à situação estudada e que são classificados pelo ILCD como passos obrigatórios para a realização da $\mathrm{ACV}$.

A intenção inicial era utilizá-lo para revisar uma ACV e avaliar se o método utilizado segue as solicitações do ILCD, mas em seguida ficou claro que ele é adequado também como guia para aplicação do estudo na forma das planilhas apresentadas no capítulo 4. 
Este método de planilhas desenvolvido durante a elaboração do trabalho foi uma importante contribuição que organizou e guiou a aplicação dos passos no desenvolvimento do estudo de ACV e pode ser aperfeiçoado para que possa auxiliar outros estudos e orientar revisões críticas.

É importante salientar que o texto do ILCD serve de base a todo momento para dirimir as dúvidas que surgem durante o processo, mas também reforçar que a separação das duas grandes etapas do trabalho: compreensão, identificação e organização dos passos (etapa 1) e aplicação dos passos identificados (etapa 2), foi grande responsável pela eficiência na aplicação da ferramenta.

Seguindo a orientação das tabelas derivadas do questionário foram desenvolvidas as fases de objetivo e escopo. A fase de objetivo é uma fase simples de ser definida já que as respostas são sobre o intenção do estudo, e a fase de escopo foi definida com a ajuda da leitura do manual do ILCD que apresenta os conceitos e as opções que podem ser seguidas.

O trabalho prático de coleta de dados e modelagem do ICV incluiu uma visita ao canteiro de obras para entender o processo produtivo, levantar dados e fotografias.

Com as informações, imagens e gravações colhidas nesta visita foi possível levantar os dados necessários para o estudo. A maioria das quantificações foram feitas pelo projeto e algumas medições foram feitas na obra.

Neste estudo não foi necessário colher dados administrativos da empresa sobre gastos, perdas ou outros, o que facilitou o trabalho por não precisar entrar em um campo delicado de coleta, onde alguns fornecedores poderiam se negar a colaborar.

Mas foi possível perceber que em muitos casos a coleta de informações administrativas e financeiras são necessárias. Assim como a coleta exaustiva de dados sobre o processo técnico, o que faz com que sejam necessárias várias visitas. Isso exige que o diálogo entre o pesquisador que está aplicando a ACV e a empresa fabricante do produto seja próximo, sob o risco de não ser possível atingir a maior precisão possível no estudo por falta de dados. 
O desenho do ciclo de vida foi feito baseado no desenho do processo produtivo do painel, de onde foram coletados os dados primários, e nas informações referentes aos seus componentes encontradas no banco de dados do software Gabi versão 6.0 .

Nesta busca de dados no banco de dados do programa, infelizmente quase nenhum dado era referente à processos brasileiros. Para o processo produtivo do concreto C20 foi encontrado um dado alemão e para o vergalhão de aço um dado global. O processo produtivo do bloco cerâmico não foi encontrado no banco de dados do programa.

Para a modelagem completa foi preciso procurar por outros dados referentes aos blocos cerâmicos. Estes dados foram encontrados no software Simapro $8.0 \mathrm{e}$ transportados para o banco de dados do Gabi 6.0 para que fosse possível completar o trabalho. São dados globais.

O processo do bloco teve que ser todo construído dentro do software e suas entradas e saídas utilizaram processos existentes no banco de dados do Gabi 6.0 neste processo foram utilizados dados de diversos locais como Europa, Estados Unidos, Alemanha, Brasil e processos globais. O processo de extração da argila não foi encontrado no banco de dados e neste caso foi substituído pelo processo de extração da areia, que era o mais próximo disponível.

Os processos referentes aos caminhões que transportam os materiais são processos globais e o processo produtivo do diesel, combustível dos caminhões, foi um dos poucos dados brasileiros utilizados.

Para um resultado preciso o ideal seria que todos os dados fossem brasileiros. As técnicas, a mão de obra, a matriz energética e diversos outros processos são muito diferentes de região para região.

Os processos deste estudo foram encontrados em um pacote de dados padrão, que é instalado junto com o programa. A PE International oferece para compra outros pacotes de dados, inclusive um sobre materiais de construção. As informações sobre os dados que integram este banco de dados estão disponíveis em: http://database-documentation.gabi-software.com/index.php?id=8548 (Acesso em 27/11/2014). 
Foi verificado que neste pacote de dados de materiais de construção da PE International constam alguns dados brasileiros, listados na tabela 31 .

\begin{tabular}{|l|l|l|}
\hline \multicolumn{2}{|c|}{$\begin{array}{l}\text { DADOS BRASILEIROS NO BANCO DE DADOS ME MATERIAIS DE CONSTRUÇÃO } \\
\text { DISPONÍvEL PARA COMPRA NO SITE DA PE INTERNATIONAL EM 28/11/2014 }\end{array}$} \\
\hline Alumínio (perfil e chapa) & Manta para telhado verde & Argamassa \\
\hline Chapa de betume & Coletor plano (uso) & $\begin{array}{l}\text { Laje de concreto pré- } \\
\text { fabricada (20 e 40cm) }\end{array}$ \\
\hline Cimento (média) & $\begin{array}{l}\text { Aquecedor a gás baixa } \\
\text { temperatura }\end{array}$ & $\begin{array}{l}\text { Bombeamento de } 1 \mathrm{~m}^{3} \text { de } \\
\text { concreto }\end{array}$ \\
\hline Blocos de concreto & Cascalho (2-32mm) & Telhas de pvc \\
\hline $\begin{array}{l}\text { Concreto de várias } \\
\text { resistências }\end{array}$ & Gesso & Reciclagem de alumínio \\
\hline Entulhos em aterros & Gesso acartonado & $\begin{array}{l}\text { Reciclagem de chapas de } \\
\text { cobre }\end{array}$ \\
\hline Folha de cobre & Massa de gesso & $\begin{array}{l}\text { Reciclagem de peças de } \\
\text { aço }\end{array}$ \\
\hline Brita (16-32mm/2-15mm) & Cal hidratada & $\begin{array}{l}\text { Reciclagem de chapas de } \\
\text { aço galvanizado }\end{array}$ \\
\hline Areia 0/2 & Chapa de chumbo & Gesso reforçado \\
\hline Energia de hidrelétricas & Aterro de lixo doméstico & Telha de barro \\
\hline Energia eólica & $\begin{array}{l}\text { Iluminação (1Kw de } \\
\text { consumo) }\end{array}$ & $\begin{array}{l}\text { ar-condicionado } \\
\text { residencial (uso) }\end{array}$ \\
\hline Tijolo aparente & & $\begin{array}{l}\text { Mosaico de grés } \\
\text { (vitrificado e não } \\
\text { vitrificado) }\end{array}$ \\
\hline Caminhão (7,5t/26t/14t) & Malha estrutural de madeira & Madeira teca \\
\hline Rede mista de eletricidade & Cal & $\begin{array}{l}\text { Tacos } \\
\text { Elevadores (baixa, média e } \\
\text { alta utilização) }\end{array}$ \\
\hline $\begin{array}{l}\text { Escavadora de areia } \\
\text { (100Kw/15Kw) }\end{array}$ & Massa de cal e gesso & Argamassa para cerâmica \\
\hline Manta mineral & Madeira de pinho \\
\hline
\end{tabular}

Tabela 35: Dados brasileiros no banco de dados disponível para compra da PE International.

Seria interessante a montagem de um banco de dados para a construção brasileira disponível para todos os pesquisadores com informações para materiais, começando pelos insumos mais básicos até chegar a componentes mais completos.

Segundo Adamus (2014), é de crucial importância a disponibilidade do banco de dados ambientais sobre materiais de construção e o desenvolvimento de ferramentas de gerenciamento destes dados que ofereçam acesso fácil para os 
profissionais, resultando na intensificação do uso dos dados durante a atividade de projeto e construção, considerando todos os estágios do ciclo de vida da edificação.

Uma padronização na apresentação dos dados referentes a cada material também é importante pois quando o processos não constam nos banco de dados dos softwares eles precisam ser modelados lá, e a fácil compreensão do inventário de entradas e saídas é importante para este trabalho.

Os objetivos definidos na fase de objetivo do estudo foram atingidos, a ferramenta da ACV foi aplicada com sucesso e os impactos da produção foram quantificados. Os limites do sistema foram respeitados. Foram usados dados primários e secundários como previsto e os passos da metodologia do ILCD foram seguidos.

Foram gerados dados nacionais para a construção do painel de blocos cerâmicos e concreto armado, embora não tão precisos devido às limitações já comentadas dos bancos de dados. Mas, com o sistema montado, fica um trabalho a ser aperfeiçoado com a substituição dos processos internacionais por processos nacionais assim que estiverem acessíveis.

A tabela 36 identifica, segundo o desenvolvimento do trabalho relatado acima, quais foram os passos classificados como gargalos na aplicação da ACV.

Tabela 36: Gargalos na aplicação da matodologia do ILCD e na realização da ACV.

GARGALOS NA APLICAÇÃO DA METODOLOGIA DO ILCD

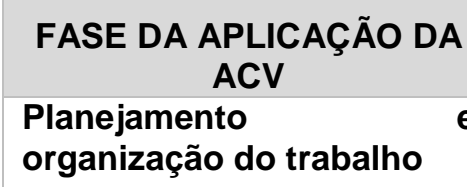

FASE DA APLICAÇÃO DA ACV

Planejamento organização do trabalho

COMENTÁRIO

e É necessário que o trabalho de compreensão, identificação e organização dos passos a serem aplicados seja feito por uma pessoa especializada.

\section{Coleta de dados}

É uma fase longa e muitas vezes pode

\section{POSSÍVEIS SOLUÇÕES}

- treinar pessoal;

- desenvolver um método

de organização pré-

configurado para as situações propostas nos manuais conforme 0 proposto nesta pesquisa, que passem por uma revisão de um especialista em cada caso mas que possa ser utilizada por outros profissionais da equipe que passem por um treinamento rápido.

- Incentivo para que as empresas realizem a ACV 


\begin{tabular}{|c|c|c|}
\hline & $\begin{array}{l}\text { dificuldades de acesso à dados } \\
\text { necessários, o que pode } \\
\text { obrigar a utilização de dados } \\
\text { genéricos que comprometem o } \\
\text { resultado do estudo. }\end{array}$ & $\begin{array}{l}\text { dos seus produtos fazendo } \\
\text { com que os produtores } \\
\text { sejam partes interessadas } \\
\text { no fornecimento dos dados. } \\
\text { - criação de um banco de } \\
\text { dados nacional acessível } \\
\text { aos profissionais } \\
\text { pesquisadores. }\end{array}$ \\
\hline Qualidade dos dados & $\begin{array}{l}\text { Os dados disponíveis em } \\
\text { bancos de dados raramente } \\
\text { são brasileiros. São em sua } \\
\text { maioria europeus, americanos } \\
\text { e alguns considerados globais. } \\
\text { Isso significa que a maior parte } \\
\text { dos países estão em situação } \\
\text { semelhante à do Brasil, onde é } \\
\text { difícil chegar a resultados reais } \\
\text { na aplicação da ACV. }\end{array}$ & $\begin{array}{l}\text { - ampliar as pesquisas } \\
\text { sobre ACV; } \\
\text { - publicação de um banco } \\
\text { de dados nacional; }\end{array}$ \\
\hline
\end{tabular}

As principais contribuições resultantes desta experiência de aplicação da ferramenta de ACV segundo a metodologia do ILCD no painel de blocos cerâmicos e concreto armado concernem aos resultados da ACV referentes ao painel e à metodologia aplicada para a utilização das orientações do ILCD na aplicação da ACV.

Com relação aos resultados referentes ao painel, foram gerados dados que podem ser disponibilizados em um banco de dados nacional, que possibilite a comparação com dados de outros materiais com a mesma função de vedação vertical e podem auxiliar na especificação durante a fase de projeto e assim contribuir com a possibilidade de construções com menor impacto ambiental.

O método que foi desenvolvido durante a aplicação da ACV, para facilitar a compreensão e utilização do ILCD, consistente nas perguntas e tabelas elaboradas, pode ser utilizado:

- Para a orientação na aplicação da ACV por meio dos passos organizados nas tabelas;

- Para a orientação na avaliação de acvs por terceiros por meio das respostas às perguntas do questionário; 
- Para o treinamento de aplicadores e avaliadores por ser um meio simplificado e de fácil compreensão de aplicação da metodologia do ILCD.

Assim, os resultados vão ao encontro das intenções do PBACV, no que diz respeito:

- À contribuição com dados nacionais;

- À formação de pessoas especializadas;

- Ao apoio ao desenvolvimento e o acesso à mecanismos de distribuição de informações sobre o conceito do ciclo de vida;

- E à compreensão da metodologia do ilcd, adotada como padrão pelo pbacv.

(http://pbacv.blogspot.com.br/p/quem-somos.html em12/01/2015) 
Referências Bibliográficas

ADAMUS, Lukasz; Environmentally friendly construction products selection based on building model data. Creative Construction Conference 2014. Procedia Engineering 85. Polônia, 2014.

BISWAS, Wahidul K.; Carbon footprint and embodied energy consumption assessment of building construction works in Western Australia. International Journal of Sustainable Built Environment, v.3, p. 179-186, Austrália, 2014.

BLUMENSCHEIN, Raquel Naves; A sustentabilidade na cadeia produtiva da indústria da construção. Centro de Desenvolvimento Sustentável, Universidade de Brasília. Brasília. 2004.

BRANDÃO, Douglas Queiroz; HEINECK, Luiz Fernando Mahlmann; Significado multidimensional e dinâmico do morar: compreendendo as modificações na fase de uso e propondo flexibilidade nas habitações sociais. Revista Ambiente Construído, v.3, n.4, p35-48. Porto Alegre, 2003.

BRE. Methodology for Enviromental Profiles os Construction Products: Product Category Rules for Type III environmental product declaration of construction products. DRAFT - UK, august 2007.

BUENO, Cristiane; FABRICIO, Márcio Minto; ROSSIGNOLO, João Adriano. Avaliação de ciclo de vida de componentes construtivos como ferramenta de decisão no processo de projeto. $2^{\circ}$. Simpósio Brasileiro de Qualidade do Projeto no Ambiente Construído. X Workshop Brasileiro de Gestão do Processo de Projeto na Construção de Edifícios, 03 e 04 de Novembro de 2011 - Rio de Janeiro, RJ - Brasil

CALDEIRA PIRES, Armando. SOUZA-PAULA, Maria Carlota. VILLAS BÔAS, Roberto C. Avaliação de Ciclo de Vida - A ISO 14040 na América Latina. Brasília, Abipti, 2005.

CALDEIRA PIRES, Armando; GRACE, Geórgia; BLUMENSCHEIN, Raquel Naves; Relatório Oficina 2: GT da construção do PBACV - Avaliação do Ciclo de Vida. Brasília, julho 2013. 
CÉSAR, Cristina Guimarães; ROMAN, Humberto Ramos; Desenvolvimento de um processo construtivo racionalizado: painéis pré-fabricados com blocos cerâmicos. Coletânea Habitare - vol. 6 - Inovação Tecnológica na Construção Habitacional, pag. 116 - 141, 2006.

CONMETRO. Resolução no 4, de 15 de dezembro de 2010. Dispões sobre a aprovação do Programa Brasileiro de Avaliação do Ciclo de Vida e dá outras providências. Diário Oficial da União, ano CXLVIII, ํㅡㄹ, Seção 1, Brasília.

CHANG, Yuan; RIES, Robert J.; LEI Shuhua; The embodied energy and emissions of a high-rise educational building: a quantification using process-based hybrid life cycle inventory model. Energy and Buildings v. 55, p. 790-798, China, 2012.

FRANZONI, Elisa; Materials selection for green buildings: which tools for engineers and architects? International Conference on Green Buildings and Sustainable Cities, Bolonha, 2011.

HELPA, Camile de Fátima; SOARES, Sebastião Roberto; Avaliação do ciclo de vida na construção civil brasileira: contextualização, estado da arte e perspectivas. VI Encontro Nacional e IV Encontro Latino-americano sobre Edificações e Comunidades Sustentáveis, Vitória - ES, setembro de 2011.

HUBERMAN, N.; PEARLMUTTER, D.; A life-cycle energy analysis of building materials in the Negev desert. Energy and Buildings v. 40, p. 837-848, Israel, 2007.

GERILLA, G.P.; TEKNOMO, K.; HOKAO, k.; An environmental assessment of wood and steel reinforced concrete housing construction. Building and Environmental n.42, p.2778-2784, 2007.

GUARDIGLI, Luca; MONARI, Filippo; BRAGADIN, Marco Alvise; Assessing environmental impact of green buildings through LCA methods: a comparison between reinforced concrete and wood structures in the European context. International Conference on Green Buildings and Sustainable Cities - Bolonha 2011.

GUGGEMOS, Angela A.; HORVATH, Arpad; Comparison of Environmental Effects of Steel and Concrete Framed Buildings. Journal of Infrastructure Systems, n.11, p. 93-101. Estados Unidos, 2005. 
JÚNIOR, A. F. B.; MORAIS, R. M.; EMERENCIANO, S. V.; PIMENTA H. C. D.; Conceito e aplicações de Análise de Ciclo de Vida (ACV) no Brasil. Revista Gerenciais, São Paulo, v. 7, n. 1, p. 39-44, 2008.

KEOLEIAN, Gregory A.; KENDALL, Alissa; DETTING, Jonathan E.; SMITH, Vanessa M.; CHANDLER, Richard F.; LEPECH, Michael D.; LI, Victor C. Life cycle modeling of concrete bridge design: comparison of engineered cementitious composite link slabs and conventional steel expansion joints. Journal of Infrastructure Systems, n.11, p. 51-60. Estados Unidos, 2005.

KOFOWOROLA, O.F.; GHEEWALA, S.; Life cycle energy assessment of a typical office building in Thailand. Energy and Buildings v. 41, p. 1076-1083, Tailândia, 2009.

KUHN, Eugenia Aumond; Avaliação da sustentabilidade ambiental do protótipo de habitação de interesse social Alvorada. Universidade Federal do Rio Grande do Sul. Porto Alegre, 2006.

LIBRELOTTO, Diógenes; JALALI, Said; Aplicação de uma ferramenta de análise do ciclo de vida em edificações residenciais - estudo de caso. Engenharia Civil UM n.30, Portugal, 2008.

LIMA, Angela Maria Ferreira. Avaliação de Ciclo de Vida no Brasil: Inserções e Perspectivas. Escola Politécnica, Universidade Federal da Bahia. Salvador, 2007.

MORA, Eduardo P.; Life Cycle, sustainability and the transcendent quality of buildings materials. Building and Environment n.42, p.1329-1334, Espanha, 2007.

MONAHAN, J; POWELL, J.C.; An Embodied carbono and energy analysis of modern methods of construction in housing: a case study using a lifecycle assessment framework. Energy and Building, n. 43, p. 179-188, UK, 2011.

ORTIZ, Oscar; CASTELLS, Francesc; SONNEMANN, Guido. Sustainability em the Construction Industry: a review of Recent Developments Based on LCA. Construction and Building Materials, n.23. p. 28-39. Espanha, 2009.

ROSSI, Bárbara; MARIQUE, Anne-Françoise; GLAUMANN, Mauritz; REITER, Sigrid; Life-cycle assessment of residential buildings in three different European locations, basic tool. Building and Environment n.51, p.395-402, Suécia, 2012. 
SABBATINI, Fernando Henrique. A Industrialização e o processo de produção de vedações verticais: utopia ou elemento de competitividade industrial? Seminário Tecnologia e Gestão na Produção de Edifícios - Vedações Verticais. São Paulo, 1998.

SANTOS, Maria Fernanda Nóbrega dos; HORI, Clara Yoshico; JULIOTI, Plínio Silvio; Importância da Avaliação de Ciclo de Vida na Análise de Produtos: Possíveis Aplicações na Construção Civil. GEPROS. Gestão da Produção, Operação e Sistemas. Ano 6, no2, p. 57-76, 2011.

SOARES, José Mário Doleys; SANTOS, Marcus Daniel Friederich dos; KROTH, Leandro Agostinho; RAUBER, Felipe Claus. Construção de Habitações de Interesse Social. Coletânea Habitare - vol. 6 - Inovação Tecnológica na Construção Habitacional. p. 161-187, 2006.

SOARES, S. R.; SOUZA, D. M.; PEREIRA, S.W. A avaliação do ciclo de vida no contexto da construção civil. Coletânea Habitare - vol. 7 - Construção e Meio Ambiente. p. 97-127, 2006.

THIERS, Stéphane; PEUPORTIER, Bruno; Energy and environmental assessment of two high energy performance residential buildings. Building and Environment, n.51, p. 276-284, França 2012.

TORGAL, F. Pacheco; JALALI, Said; A Sustentabilidade dos Materiais de Construção. Ed. Tecminho. Vila Verde, Portugal. 2010.

XING, Su; XU, Zhang; JUN, Gao; Inventory Analysis of LCA on steel and concrete construction office buildings. Energy and Building, n. 40, p. 1188-1193, China, 2011.

ZANONE, Vanda Alice Garcia; SANCHEZ, José Manoel Morales; Sistemas construtivos inovadores: uma abordagem analítica a partir das diretrizes e dos documentos de avaliação técnica do SINAT. XIV ENTAC - Encontro Nacional de Tecnologia do Ambiente Construído. Juíz de Fora, outubro de 2012.

ZANONE, Vanda Alice Garcia; SÁNCHEZ, José Manuel Morales; Estágio de Desenvolvimento Tecnológico dos Painéis Pré-Fabricados com Blocos Cerâmicos. XIV ENTAC - Encontro Nacional de Tecnologia do Ambiente Construído. Juíz de Fora, outubro de 2012. 
ZAPATA, Paplo; GAMBATESE, John A.; Energy consumption of asphalt and reinforced concrete pavement materials and construction. Journal of Infrastructure Systems, n.11, p. 9-20. Estados Unidos, 2005.

WEIBENBERGER, Markus; JENSCHB, Werner; LANGC, Werner; The convergence of life cicle assesment and nearly zero-energy buildings: the case of Germany. Energy and Building magazine. Alemanha, março de 2014.

WOLF, Marc-Andree; PANT, Rana; CHOMKHAMSRI, Kirana; SALA, Serenella; PENNINGTON, David; European Commission - Joint Research Centre - Institute for Environment and Sustainability: International Reference Life Cycle Data System (ILCD) Handbook. Luxembourg. Publications Office of the European Union, 2012.

ABNT; NBR 6120 Cargas para o Cálculo de Estruturas de Edificaçoes. Rio de Janeiro, novembro de 1980.

ABNT; NBR ISO 14040 Gestão Ambiental - Avaliação de ciclo de vida - Princípios e estrutura. Rio de Janeiro, maio de 2009

BRE GLOBAL LTD.; BRE Global Product Category Rules for Tipe III Environmental Product Declaration of Construction Products to EN 15804:2012+A1:2013. Reino Unido, 2014.

BRE GLOBAL LTD.; BRE Global Methodology for Environmental Profiles of Construction Products. SD6050. Reino Unido, 2008.

EUROPEAN COMISSION- Joint Research Centre - Institute for Environment and Sustainability: International Reference Life Cycle Data System (ILCD) Handbook General guide for Life Cycle Assessment - Detailed guidance. First edition March 2010. EUR 24708 EN. Luxembourg. Publications Office of the European Union, 2010

EUROPEAN COMISSION - Joint Research Centre - Institute for Environment and Sustainability: International Reference Life Cycle Data System (ILCD) Handbook General guide for Life Cycle Assessment - Provisions and Action Steps. First edition March 2010. EUR 24378 EN. Luxembourg. Publications Office of the European Union; 2010. 
MINISTÉRIO DAS CIDADES; Secretaria Nacional de Habitação; Déficit Habitacional no Brasil 2008. Brasília, 2011.

MINISTÉRIO DAS CIDADES; A Política Naciaonal de Habitação. Brasília, 2004.

NHBC FOUNDATION; A Guide to Modern Methods of Construction. Amersham, 2006.

CAIXA ECONÔMICA FEDERAL; Dois Milhões de Casas para os brasileiros. Disponível em: http://www.caixa.gov.br/habitacao/mcmv/ Acesso em 03/03/2013.

CBCS; Materiais, Componentes e a Construção Sustentável. São Paulo,2009. Disponível em:

http://www.cbcs.org.br/ 5dotSystem/userFiles/posicionamentos/CBCS CTMateriais Posicionamento Materiais\%20componentes.pdf Acesso em 23/09/2014.

GERDAU; Catálogo Aço para a Construção Civil. Disponível em https://www.comercialgerdau.com.br/produtos/download/catalogos/catalogo aco par a constru\%C3\%A7ao civil.pdf Acesso em 28/10/2014.

GERDAU; Página da web. Disponível em: http://www.gerdau.com.br/sobregerdau/unidades-no-brasil.aspx Acesso em 31/10/2014

PBACV; Blogspot. Disponível em: http://pbacv.blogspot.com.br/p/quem-somos.html Acesso em 12/01/2015. 
Anexo 01: Exemplo de artigos que utilizam ACV para o desenvolvimento da CPIC.

\begin{tabular}{|c|c|c|c|c|c|}
\hline \multicolumn{6}{|c|}{$\begin{array}{l}\text { EXEMPLO DE ARTIGOS QUE UTILIZAM ACV PARA O } \\
\text { DESENVOLVIMENTO DA CPIC }\end{array}$} \\
\hline $\begin{array}{l}\text { TíTULO E } \\
\text { AUTORES }\end{array}$ & PUBLICAÇÃO & RESUMO & LOCAL & ANO & RESULTADOS \\
\hline $\begin{array}{l}\text { Life cycle } \\
\text { modeling of } \\
\text { concrete bridge } \\
\text { design: } \\
\text { comparison of } \\
\text { engineered } \\
\text { cementitious } \\
\text { composite link } \\
\text { slabs and } \\
\text { conventional steel } \\
\text { expansion joints. } \\
\text { KEOLEIAN, G.A. } \\
\text { Et al. }\end{array}$ & $\begin{array}{l}\text { Journal of } \\
\text { infrastructure } \\
\text { Systems }\end{array}$ & $\begin{array}{l}\text { Compara o } \\
\text { desempenho } \\
\text { ambiental de } \\
\text { duas pontes, } \\
\text { uma utilizando } \\
\text { juntas de } \\
\text { dilatação de } \\
\text { aço (sistema } \\
\text { tradicional) e } \\
\text { outra } \\
\text { utilizando lajes } \\
\text { de ligação } \\
\text { com novos } \\
\text { compostos } \\
\text { cimentícios } \\
\text { (sistema } \\
\text { novo). }\end{array}$ & $\begin{array}{l}\text { Estados } \\
\text { Unidos }\end{array}$ & 2005 & $\begin{array}{l}\text { O estudo } \\
\text { demonstrou que } \\
\text { o novo sistema } \\
\text { tem menor } \\
\text { impacto em todas } \\
\text { as categorias } \\
\text { avaliadas devido } \\
\text { à maior } \\
\text { resistência do } \\
\text { material, maior } \\
\text { durabilidade e } \\
\text { menor } \\
\text { necessidade de } \\
\text { manutenção. }\end{array}$ \\
\hline $\begin{array}{l}\text { Energy } \\
\text { consumption of } \\
\text { asphalt and } \\
\text { reinforced } \\
\text { concrete } \\
\text { pavement } \\
\text { materials and } \\
\text { construction. } \\
\text { ZAPATA, P. } \\
\text { GAMBATESE, J. }\end{array}$ & $\begin{array}{l}\text { Journal of } \\
\text { infrastructure } \\
\text { Systems }\end{array}$ & $\begin{array}{l}\text { Apresenta } \\
\text { uma avaliação } \\
\text { de inventário } \\
\text { de ciclo de } \\
\text { vida de } \\
\text { pavimentação } \\
\text { em concreto } \\
\text { armado e em } \\
\text { asfalto e } \\
\text { compara o } \\
\text { consumo de } \\
\text { energia na } \\
\text { aplicação } \\
\text { destes } \\
\text { materiais na } \\
\text { pavimentação } \\
\text { de uma } \\
\text { rodovia. }\end{array}$ & $\begin{array}{l}\text { Estados } \\
\text { Unidos }\end{array}$ & 2005 & $\begin{array}{l}\text { O estudo conclui } \\
\text { que no mesmo } \\
\text { período de vida a } \\
\text { pavimentação em } \\
\text { concreto armado } \\
\text { concome mais } \\
\text { energia que em } \\
\text { asfalto nas fases } \\
\text { de extração de } \\
\text { matéria prima à } \\
\text { construção e } \\
\text { sugere mudanças } \\
\text { nos processos } \\
\text { para melhorias. }\end{array}$ \\
\hline
\end{tabular}




\begin{tabular}{|c|c|c|c|c|c|}
\hline $\begin{array}{l}\text { Comparison of } \\
\text { Environmental } \\
\text { Effects of Steel } \\
\text { and Concrete } \\
\text { Framed Buildings. } \\
\text { GUGGEMOS, } \\
\text { A.A. } \\
\text { HORVATH, A. }\end{array}$ & $\begin{array}{l}\text { Journal of } \\
\text { infrastructure } \\
\text { Systems }\end{array}$ & $\begin{array}{l}\text { Usa a ACV } \\
\text { para } \\
\text { quantificar a } \\
\text { energia } \\
\text { consumida e } \\
\text { as emissões } \\
\text { durante a fase } \\
\text { de construção } \\
\text { de dois } \\
\text { edifícios de } \\
\text { escritórios, um } \\
\text { com estrutura } \\
\text { de aço e outro } \\
\text { de concreto. }\end{array}$ & $\begin{array}{l}\text { Estados } \\
\text { Unidos }\end{array}$ & 2005 & $\begin{array}{l}\text { O estudo conclui } \\
\text { que a energia } \\
\text { consumida e as } \\
\text { emissões dos } \\
\text { dois tipos de } \\
\text { estrutura são } \\
\text { similares e indica } \\
\text { que as melhores } \\
\text { possibilidades de } \\
\text { melhoria no } \\
\text { desempenhoestã } \\
\text { o na seleção de } \\
\text { materiais, no uso } \\
\text { de materiais } \\
\text { temporários e na } \\
\text { qualidade dos } \\
\text { equipamentos } \\
\text { utilizados na obra. }\end{array}$ \\
\hline $\begin{array}{l}\text { An environmental } \\
\text { assessment of } \\
\text { wood and steel } \\
\text { reinforced } \\
\text { concrete housing } \\
\text { construction. } \\
\text { GERILLA, G.P. } \\
\text { TEKNOMO, K. } \\
\text { HOKAO, k. }\end{array}$ & $\begin{array}{l}\text { Building and } \\
\text { Environment } 42\end{array}$ & $\begin{array}{l}\text { Avalia os } \\
\text { impactos } \\
\text { ambientais de } \\
\text { residências } \\
\text { construídas } \\
\text { em madeira e } \\
\text { em concreto } \\
\text { armado no } \\
\text { Japão. }\end{array}$ & Japão & 2006 & $\begin{array}{l}\text { O estudo conclui } \\
\text { que a emissão de } \\
\text { dióxido de } \\
\text { carbono é o } \\
\text { principal impacto } \\
\text { associado à } \\
\text { construção das } \\
\text { residências e que } \\
\text { as construídas } \\
\text { em madeira } \\
\text { apresentam } \\
\text { menores } \\
\text { emissões. }\end{array}$ \\
\hline $\begin{array}{l}\text { Life Cycle, } \\
\text { sustainability and } \\
\text { the transcendent } \\
\text { quality of } \\
\text { buildings } \\
\text { materials. } \\
\text { MORA, E. P. }\end{array}$ & $\begin{array}{l}\text { Building and } \\
\text { Environment } 42\end{array}$ & $\begin{array}{l}\text { Fala sobre a } \\
\text { relação entre a } \\
\text { sustentabilidad } \\
\text { e e a } \\
\text { durabilidade } \\
\text { das obras de } \\
\text { engenharia e } \\
\text { estuda os } \\
\text { impactos do } \\
\text { crescimento } \\
\text { urbano na } \\
\text { extração de } \\
\text { matérias } \\
\text { primas. }\end{array}$ & Espanha & 2007 & $\begin{array}{l}\text { O texto conclui } \\
\text { que para ser } \\
\text { sustentável a } \\
\text { edificação tem } \\
\text { que ser durável e } \\
\text { que isso pode ser } \\
\text { atingido pelo udo } \\
\text { de materiais } \\
\text { duráveis e pelo } \\
\text { uso de sistemas } \\
\text { construtivos que } \\
\text { permitam } \\
\text { manutenção, e } \\
\text { que a ACV } \\
\text { contribui com a } \\
\text { identificação } \\
\text { destas } \\
\text { tecnologias. }\end{array}$ \\
\hline
\end{tabular}




\begin{tabular}{|c|c|c|c|c|c|}
\hline $\begin{array}{l}\text { A life-cycle } \\
\text { energy analysis of } \\
\text { building materials } \\
\text { in the Negev } \\
\text { desert. } \\
\text { HUBERMAN, N. } \\
\text { PEARLMUTTER, } \\
\text { D. }\end{array}$ & $\begin{array}{l}\text { Energy and } \\
\text { Buildings } 40\end{array}$ & $\begin{array}{l}\text { Este estudo } \\
\text { busca } \\
\text { identificar } \\
\text { materiais de } \\
\text { construção } \\
\text { que possam } \\
\text { otimizar a } \\
\text { demanda de } \\
\text { energia } \\
\text { durante todo o } \\
\text { ciclo de vida } \\
\text { de um edifício } \\
\text { projetado com } \\
\text { princípios de } \\
\text { conforto } \\
\text { ambiental no } \\
\text { deserto do } \\
\text { Negev. }\end{array}$ & Israel & 2007 & $\begin{array}{l}\text { A energia } \\
\text { incorporada na } \\
\text { fase de contrução } \\
\text { da edificação em } \\
\text { questão } \\
\text { corresponde a } \\
\text { uma grande } \\
\text { parcela da } \\
\text { energia } \\
\text { consumida } \\
\text { durante o ciclo de } \\
\text { vida e a adoção } \\
\text { dos materiais } \\
\text { alternativos } \\
\text { analisados } \\
\text { apresentam bons } \\
\text { resultados na } \\
\text { minimização do } \\
\text { consumo. }\end{array}$ \\
\hline $\begin{array}{l}\text { Inventory Analysis } \\
\text { of LCA on steel } \\
\text { and concrete } \\
\text { construction office } \\
\text { buildings. } \\
\text { XING, S. } \\
\text { XU, Z. } \\
\text { JUN, G. }\end{array}$ & $\begin{array}{l}\text { Energy and } \\
\text { Buildings } 40\end{array}$ & $\begin{array}{l}\text { Desenvolve } \\
\text { um modelo de } \\
\text { ICV para } \\
\text { edifícios de } \\
\text { escritórios e } \\
\text { compara os } \\
\text { impactos } \\
\text { ambientais de } \\
\text { dois edifícios, } \\
\text { um com } \\
\text { estrutura de } \\
\text { aço e outro de } \\
\text { concreto da } \\
\text { fase de } \\
\text { extração de } \\
\text { materiais à } \\
\text { fase de uso. }\end{array}$ & China & 2008 & $\begin{array}{l}\text { O estudo conclui } \\
\text { que o edifício com } \\
\text { estrutura em aço } \\
\text { consome menos } \\
\text { energia e produz } \\
\text { menores } \\
\text { emissões na fase } \\
\text { de construção } \\
\text { mas essa } \\
\text { situação se } \\
\text { reverte na fase de } \\
\text { uso devido a alta } \\
\text { condutibilidade } \\
\text { térmica do aço e } \\
\text { um consequente } \\
\text { maior uso de ar- } \\
\text { condicionados. }\end{array}$ \\
\hline $\begin{array}{l}\text { Aplicação de uma } \\
\text { ferramenta de } \\
\text { análise do ciclo } \\
\text { de vida em } \\
\text { edificações } \\
\text { residenciais - } \\
\text { estudo de caso. } \\
\text { LIBRELOTTO, D. } \\
\text { JALALI, S. }\end{array}$ & $\begin{array}{l}\text { Engenharia Civil } \\
\text { - UM } 30\end{array}$ & $\begin{array}{l}\text { Aplicação da } \\
\text { ACV usando o } \\
\text { programa } \\
\text { GBTool } 2005 \\
\text { em dois } \\
\text { edifícios } \\
\text { residenciais } \\
\text { em Cruz Alta, } \\
\text { RS, Brasil. } \\
\text { Após os } \\
\text { resultados } \\
\text { propõe } \\
\text { modificações } \\
\text { para melhorar } \\
\text { o desempenho }\end{array}$ & Portugal & 2008 & $\begin{array}{l}\text { O estudo conclui } \\
\text { que a ferramenta } \\
\text { GBTool } 2005 \text { é } \\
\text { adequada para a } \\
\text { realização do } \\
\text { estudo, que se } \\
\text { diferencia de } \\
\text { outras } \\
\text { ferramentas por } \\
\text { permitir edição de } \\
\text { dados e } \\
\text { adequação de } \\
\text { cenários e por } \\
\text { calcular a energia } \\
\text { incorporada além }\end{array}$ \\
\hline
\end{tabular}




\begin{tabular}{|c|c|c|c|c|c|}
\hline & & $\begin{array}{l}\text { ambiental das } \\
\text { edificações. }\end{array}$ & & & $\begin{array}{l}\text { das emissões de } \\
\text { CO2. }\end{array}$ \\
\hline $\begin{array}{l}\text { An embodied } \\
\text { carbon and } \\
\text { energy analysis of } \\
\text { modern methods } \\
\text { of construction in } \\
\text { housing: a case } \\
\text { study using a } \\
\text { lifecycle } \\
\text { assessment } \\
\text { framework. } \\
\text { MONAHAN, J. } \\
\text { POWELL, J.C. }\end{array}$ & $\begin{array}{l}\text { Energy and } \\
\text { Buildings } 43\end{array}$ & $\begin{array}{l}\text { Compara o } \\
\text { desempenho } \\
\text { da construção } \\
\text { de uma } \\
\text { residência em } \\
\text { estrutura } \\
\text { modular e } \\
\text { revestimentos } \\
\text { de madeira, } \\
\text { em estrutura } \\
\text { modular de } \\
\text { madeira e } \\
\text { revestimentos } \\
\text { em tijolos e } \\
\text { em estrutura } \\
\text { tradicional de } \\
\text { concreto e } \\
\text { alvenaria. }\end{array}$ & $\begin{array}{l}\text { Reino } \\
\text { Unido }\end{array}$ & 2011 & $\begin{array}{l}\text { Conclui que a } \\
\text { residência com } \\
\text { estrutura e } \\
\text { revestimentos em } \\
\text { madeira pré- } \\
\text { fabricados reduz } \\
\text { em } 51 \% \text { as } \\
\text { emissões de } \\
\text { CO2. }\end{array}$ \\
\hline $\begin{array}{l}\text { Energy and } \\
\text { environmental } \\
\text { assessment of } \\
\text { two high energy } \\
\text { performance } \\
\text { residential } \\
\text { buildings. } \\
\text { THIERS, S. } \\
\text { PEUPORTIER, B. }\end{array}$ & $\begin{array}{l}\text { Building and } \\
\text { Environment } 51\end{array}$ & $\begin{array}{l}\text { Avalia através } \\
\text { da ACV duas } \\
\text { edificações } \\
\text { consideradas } \\
\text { energeticamen } \\
\text { te eficientes } \\
\text { para concluir } \\
\text { sobre energia } \\
\text { incorporada } \\
\text { total. Compara } \\
\text { quatro tipos de } \\
\text { sistemas de } \\
\text { aquecimento. }\end{array}$ & França & 2011 & $\begin{array}{l}\text { Conclui que } \\
\text { edifícios novos } \\
\text { têm melhor } \\
\text { desempenho } \\
\text { ambiental do que } \\
\text { edifícios } \\
\text { reformados. } \\
\text { Avalia várias } \\
\text { categorias de } \\
\text { impactos e } \\
\text { conclui que } \\
\text { nenhum dos } \\
\text { tipos de } \\
\text { aquecimento tem } \\
\text { bons resultados } \\
\text { em todas, } \\
\text { deixando as } \\
\text { decisões a critério } \\
\text { das situações, e } \\
\text { aconselha } \\
\text { economia de } \\
\text { energia em todos } \\
\text { os casos. }\end{array}$ \\
\hline $\begin{array}{l}\text { Assessing } \\
\text { environmental } \\
\text { impact of green } \\
\text { buildings through } \\
\text { LCA methods: a } \\
\text { comparison } \\
\text { between }\end{array}$ & $\begin{array}{l}\text { Procedia } \\
\text { Engineering } 21\end{array}$ & $\begin{array}{l}\text { Compara o } \\
\text { desempenho } \\
\text { ambiental do } \\
\text { mesmo projeto } \\
\text { construído em } \\
\text { estrutura de } \\
\text { concreto }\end{array}$ & Itália & 2011 & $\begin{array}{l}\text { Conclui que os } \\
\text { impactos na } \\
\text { saúde humana, } \\
\text { consumo de } \\
\text { recursos e } \\
\text { qualidade do } \\
\text { ecosistema são }\end{array}$ \\
\hline
\end{tabular}




\begin{tabular}{|c|c|c|c|c|c|}
\hline $\begin{array}{l}\text { reinforced } \\
\text { concrete and } \\
\text { wood structures in } \\
\text { the European } \\
\text { context. } \\
\text { GUARDIGLI, L. } \\
\text { MONARI, F. } \\
\text { BRAGADIN, M.A. }\end{array}$ & & $\begin{array}{l}\text { tradicional e } \\
\text { em estrutura } \\
\text { de madeira. }\end{array}$ & & & $\begin{array}{l}\text { menores usando } \\
\text { estrutura de } \\
\text { madeira, mas } \\
\text { deve haver a } \\
\text { preocupação com } \\
\text { o manejo } \\
\text { sustentável. Com } \\
\text { relação aos } \\
\text { custos a estrutura } \\
\text { em madeira } \\
\text { também } \\
\text { demonstrou ser } \\
\text { mais interessante. }\end{array}$ \\
\hline $\begin{array}{l}\text { Importância da } \\
\text { avaliação do ciclo } \\
\text { de vida na análise } \\
\text { de produtos: } \\
\text { possíveis } \\
\text { aplicações na } \\
\text { construção civil. } \\
\text { SANTOS, M.F.N. } \\
\text { Et al. }\end{array}$ & $\begin{array}{l}\text { Gepros - } \\
\text { Gestão da } \\
\text { Produção, } \\
\text { Operações e } \\
\text { Sistemas }\end{array}$ & $\begin{array}{l}\text { Apresenta um } \\
\text { breve histórico } \\
\text { do } \\
\text { desenvolvimen } \\
\text { to da ACV no } \\
\text { mundo e no } \\
\text { Brasil, } \\
\text { comenta sobre } \\
\text { as fases da } \\
\text { aplicação da } \\
\text { ferramenta e } \\
\text { sobre os } \\
\text { benefícios da } \\
\text { reciclagem e } \\
\text { incorporação } \\
\text { de resíduos } \\
\text { em materiais } \\
\text { de construção. }\end{array}$ & Brasil & 2011 & $\begin{array}{l}\text { Conclui que a } \\
\text { reciclagem } \\
\text { apresenta muitos } \\
\text { benefícios, mas } \\
\text { que é de extrema } \\
\text { importância } \\
\text { trabalhar na } \\
\text { diminuição da } \\
\text { geração de } \\
\text { resíduos. } \\
\text { Conclui ainda } \\
\text { que a ACV é uma } \\
\text { ferramenta } \\
\text { promissora na } \\
\text { diminuiçao de } \\
\text { impactos de } \\
\text { materiais de } \\
\text { construção. }\end{array}$ \\
\hline $\begin{array}{l}\text { Avaliação de } \\
\text { ciclo de vida de } \\
\text { components } \\
\text { construtivos como } \\
\text { ferramenta de } \\
\text { decisão no } \\
\text { processo do } \\
\text { projeto. } \\
\text { BUENO, C. } \\
\text { Et al. }\end{array}$ & $\begin{array}{l}2 \text { Simpósio } \\
\text { Brasileiro de } \\
\text { Qualidade do } \\
\text { Projeto no } \\
\text { Ambiente } \\
\text { Construído }\end{array}$ & $\begin{array}{l}\text { Levantamento } \\
\text { do estado da } \\
\text { arte da } \\
\text { aplicação da } \\
\text { ACV } \\
\text { direcionada } \\
\text { para a } \\
\text { classificação } \\
\text { de } \\
\text { componentes } \\
\text { construtivos } \\
\text { durante o } \\
\text { processo de } \\
\text { projeto. }\end{array}$ & Brasil & 2011 & $\begin{array}{l}\text { O artigo conclui } \\
\text { que apesar das } \\
\text { dificuldades em } \\
\text { se aplicar a ACV } \\
\text { na edificação } \\
\text { como um todo, a } \\
\text { aplicação em } \\
\text { seus } \\
\text { componentes } \\
\text { construtivos tem } \\
\text { apresentado } \\
\text { resultados } \\
\text { eficientes na } \\
\text { busca do melhor } \\
\text { desempenho } \\
\text { ambiental da } \\
\text { CPIC. }\end{array}$ \\
\hline $\begin{array}{l}\text { Life-cycle } \\
\text { assessment of } \\
\text { residential } \\
\text { buildings in three }\end{array}$ & $\begin{array}{l}\text { Building and } \\
\text { Environment } 51\end{array}$ & $\begin{array}{l}\text { Aplica a ACV } \\
\text { em três } \\
\text { edificações } \\
\text { residenciais, }\end{array}$ & Bélgica & 2012 & $\begin{array}{l}\text { O estudo conclui } \\
\text { que apesar de } \\
\text { apresentar } \\
\text { divergências em }\end{array}$ \\
\hline
\end{tabular}




\begin{tabular}{|c|c|c|c|c|c|}
\hline $\begin{array}{l}\text { different } \\
\text { European } \\
\text { locations, basic } \\
\text { tool. } \\
\text { ROSSI, B. } \\
\text { Et al. }\end{array}$ & & $\begin{array}{l}\text { uma na } \\
\text { Bélgica, outra } \\
\text { em Portugal e } \\
\text { outra na } \\
\text { Suécia para } \\
\text { avaliar a } \\
\text { energia } \\
\text { incorporada, o } \\
\text { carbono } \\
\text { incorporado e } \\
\text { o consumo de } \\
\text { energia por } \\
\text { meio de uma } \\
\text { ferramenta } \\
\text { apresentada } \\
\text { no estudo. }\end{array}$ & & & $\begin{array}{l}\text { comparação a } \\
\text { outras } \\
\text { ferramentas } \\
\text { quando trabalha- } \\
\text { se com diferentes } \\
\text { bancos de dados } \\
\text { e matrizes } \\
\text { energéticas, a } \\
\text { ferramenta } \\
\text { apresentada é útil } \\
\text { na fase de projeto } \\
\text { da edificação. }\end{array}$ \\
\hline $\begin{array}{l}\text { The embodied } \\
\text { energy and } \\
\text { emissions of a } \\
\text { high-rise } \\
\text { educational } \\
\text { building: a } \\
\text { quantification } \\
\text { using process- } \\
\text { based hybrid life } \\
\text { cycle inventory } \\
\text { model. } \\
\text { CHANG, Y. } \\
\text { RIES, R. } \\
\text { LEI. S. }\end{array}$ & $\begin{array}{l}\text { Energy and } \\
\text { Buildings } 55\end{array}$ & $\begin{array}{l}\text { Desenvolve } \\
\text { um modelo } \\
\text { híbrido de ICV } \\
\text { para calcular a } \\
\text { energia } \\
\text { incorporada e } \\
\text { as emissões } \\
\text { de um edifíco } \\
\text { na China e } \\
\text { compara com } \\
\text { os resultados } \\
\text { do modelo de } \\
\text { ICV tradicional } \\
\text { de entradas e } \\
\text { saídas. }\end{array}$ & China & 2012 & $\begin{array}{l}\text { Conclui que o } \\
\text { modelo híbrido de } \\
\text { ICV é mais } \\
\text { específico que o } \\
\text { tradicional e que } \\
\text { resulta em } \\
\text { valores um pouco } \\
\text { mais elevados. }\end{array}$ \\
\hline $\begin{array}{l}\text { Carbon footprint } \\
\text { and embodied } \\
\text { energy } \\
\text { consumption } \\
\text { assessment of } \\
\text { building } \\
\text { construction } \\
\text { works in Western } \\
\text { Australia. } \\
\text { BISWAS, W. }\end{array}$ & $\begin{array}{l}\text { International } \\
\text { Journal of } \\
\text { Sustainable } \\
\text { Built } \\
\text { Environment }\end{array}$ & $\begin{array}{l}\text { Usa ACV para } \\
\text { avaliar as } \\
\text { fases de } \\
\text { produção de } \\
\text { materiais, } \\
\text { construção e } \\
\text { uso de um } \\
\text { "edifício verde" }\end{array}$ & Austrália & 2014 & $\begin{array}{l}\text { Conclui que um } \\
\text { edifício com um } \\
\text { sistema eficiente } \\
\text { de gerenciamento } \\
\text { de energia pode } \\
\text { ter sua pegada de } \\
\text { carbono reduzida } \\
\text { em até } 60 \% \text { e que } \\
\text { ainda há espaço } \\
\text { para maiores } \\
\text { reduções } \\
\text { utilizando-se } \\
\text { fórmulas } \\
\text { especiais de } \\
\text { cimento e } \\
\text { alumínio e aço } \\
\text { reciclados. }\end{array}$ \\
\hline
\end{tabular}




\section{Anexo 02: Questionário derivado da metodologia do ILCD.}

Questionário:

Fase de Objetivo:

1) Qual será a aplicação do estudo?

2) Quais as limitações do estudo, como os dados que serão assumidos, quais impactos serão considerados no estudo e quais são as limitações metodológicas?

3) Quais as razões para realização do estudo?

4) Quem é o público alvo?

5) Qual o tipo de divulgação que será dada ao estudo, se interna, externa com restrições ou pública?

6) É um estudo comparativo?

7) Quem são os atores?

8) Qual será a aplicação dos resultados?

9) Em qual situação o estudo se encaixa?

Fase de escopo:

1) Qual será o método e quais serão os dados assumidos?

2) São métodos e dados consistentes (precisos e completos)?

3) O processo será documentado?

4) Qual tipo de resultado se pretende obter?

a. dados de processos de unidade;

b. dados de resultados de ICV;

c. dados de resultados de AICV;

d. estudo de ACV não comparativo;

e. estudo de ACV comparativo;

f. modelo detalhado de ICV do sistema analisado;

i. identificação de indicadores chave de performance ambiental (KEPI);

ii. Declaração ambiental de produto(EPD);

iii. critérios para selo ambiental(Tipe I Ecolabel)

iv. Ciclo de vida baseado no Tipe I Ecolabel; 
5) Qual o sistema ou processo que é estudado?

6) Qual é a sua função?

7) Qual é a unidade funcional ou o fluxo de referência - o quê, quanto por quanto tempo, como e com que eficiência?

8) Quais são os métodos de medição? São normatizados?

9) Quais são os passos da modelagem do ICV?

10)É uma ACV atributiva ou consequencial?

11)São utilizados métodos de alocação ou expansão do sistema/substituição?

12)Cobre impactos na

( ) saúde humana,

( ) no meio-ambiente natural;

( ) nos recursos naturais;

Obs. impactos causados por intervenções na tecnosfera e na ecosfera durante operação normal e anormal, excluindo acidentes.

13)Todos os estágios relevantes do ciclo de vida que são operados na tecnosfera foram incluídos dentro dos limites do sistema?

14)Existe um diagrama dos limites do sistema?

15) Existe uma lista de exclusões?

16) Qual o valor de corte (\%) a ser aplicado para os produtos, perdas ou fluxos que cruzam o sistema e não são quantificados?

17)São cobertas as categorias padrões de impacto de AICV?

( ) mudança climática;

( ) esgotamento do ozônio;

( ) toxicidade humana;

( ) inorgânicos respiratórios;

( ) radiação ionizante;

( ) formação fotoquímica de ozônio;

( ) acidificação;

( ) eutrofização;

( ) ecotoxicidade;

( ) uso da terra;

( ) esgotamento de recursos naturais;

18)São cobertas as categorias finais?

( ) danos à saúde humana; 
( ) danos ao ecossistema;

( )esgotamento de recursos naturais;

19)São identificados os dados tecnológicos? Caso sejam necessários dados que representem um processo específico, que se diferencie da operação típica, isto deve ser identificado. Como foram coletados?

20)São identificados dados geográficos?

21)São identificados os dados temporais?

22)São identificados o tipo, qualidade (representatividade, abrangência e precisão) e fonte dos dados, a precisão desejada e a incerteza permitida?

23)Os modelos de comparação são construídos de forma análoga, aplicando as mesmas regras de limites do sistema, princípios de modelagem de ICV e métodos?

24)As suposições são análogas e a qualidade dos dados são similares?

25)Processos idênticos são excluídos do sistema?

26) Sistemas comparados tem a mesma unidade funcional?

27)Foi identificada a necessidade de uma revisão crítica? O tipo de revisão e quem serão os revisores foram definidos?

28)Qual tipo de divulgação de dados foi planejada?

( ) relatório detalhado;

( ) banco de dados;

( ) relatório detalhado e banco de dados:

( ) sumário executivo - não técnico;

29)A documentação dos métodos, incertezas e fontes de dados são apropriadas e transparentes?

Fase de inventário:

1) Existe uma descrição do sistema principal e da unidade funcional?

2) Quais são os fluxos de entrada e de saída do processo?

3) O sistema analisado é atributivo ou consequencial?

Modelo atributivo:

4) Os processos foram identificados?

5) Qual é o processo central do sistema? Deve incluir unidade funcional e/ou fluxo de referência. (Nível 0) 
6) Quais outros processos fazem parte do sistema primário?(Nível 1)

7) Quais processos fazem parte do sistema secundário? (Nível 2)

8) Existem processos de nível 3?

9) Existe documentação de algum processo excluído?

10)Existe documentação de relações com outros sistemas?

11) Recomenda-se desenhar um diagrama de fluxo do sistema principal e listar os produtos e perdas que ligam o sistema principal ao sistema secundário. Existe o diagrama e listagem?

Planejamento da coleta de dados:

12) Foram identificados para quais processos precisarão ser desenvolvidos novos processos para completar o sistema?

13)Os processos para os quais serão usados dados primários e para os quais serão usados dados genéricos estão identificados?

14) As fontes dos dados estão identificadas?

Coleta de dados de LCl

15)A representatividade do processo principal, em relação à tecnologia, técnica, geografia, escopo de mercado e tempo, está identificada?

16)A unidade funcional ou o fluxo de referência estão identificados?

17) As quantidades referentes aos fluxos de entrada e saída dos processos foram especificadas?

18)Houve checagem dos dados coletados para alinhá-los com o objetivo do estudo?

19) Algum dado não pode ser encontrado?

20)Como a falta de dados foi solucionada?

( ) uso de dados genéricos

( ) uso de processos similares

( ) uso de dados de outras fontes

( ) uso de dados fornecidos por especialistas

21)Os dados não encontrados foram documentados?

Modelando o sistema 
22)Todos os processos foram convertidos na mesma unidade de medida?

23) Todos os processos e fluxos relevantes foram modelados?

24)Os dados faltantes foram completados com dados consistentes?

25)Os dados usados para substituir os faltantes são dados de qualidade?

Cálculo dos resultados do AICV (Análise do impacto do ciclo de vida)

26)Todos os fluxos elementares estão ligados à uma ou mais categorias de impacto?

27)O quantitativos dos fluxos elementares estão expressados nas unidades referentes a cada categoria?

28)Os resultados são expressados por categorias de impactos?

29)Os resultados de longo prazo (mais de 100 anos da data do estudo) foram calculados separadamente?

Interpretação dos resultados

30)Os itens significantes foram identificados?

( ) estágios do ciclo de vida com maior contribuição para impactos;

( ) categorias de impactos mais representativas;

( ) escolhas relevantes feitas durante a modelagem;

31)A modelagem de ICV é completa?

( ) cobre todos os processos relevantes;

( ) cobre tosos os fluxos elementares relevantes;

( ) o critério de corte foi respeitado;

( ) os valores são precisos?;

32)Alguma análise de sensibilidade foi aplicada?

33)A qualidade dos dados e das fontes são consistentes com os objetivos e escopo do estudo?

34)As escolhas metodológicas são consistentes com os objetivos e escopo do estudo?

35)A avaliação dos impactos é consistente com os objetivos e escopo do estudo?

36)Caso existam inconsistências, suas relevâncias foram avaliadas? 
37)Nas conclusões, existem casos com metodologia diferenciada que devem ser tratados separadamente?

38) Foi encontrado algum impacto relevante fora dos previstos pelo escopo? 